\begin{tabular}{|l|l|l|}
\hline & & \\
\hline $\begin{array}{c}\text { UnB } \\
\text { Universidade de Brasília }\end{array}$ & Universidade Federal da Paraíba & $\begin{array}{c}\text { UFRN } \\
\text { Universidade Federal do Rio Grande do } \\
\text { Norte }\end{array}$ \\
\hline \multicolumn{2}{|c|}{ Programa Multiinstitucional e Inter-Regional de Pós-graduação em Ciências Contábeis } \\
\hline
\end{tabular}

MENSURANDO CUSTOS NO SERVIÇO PÚBLICO: ESTUDO DE CASO SOBRE A APLICAÇÃO DO MÉTODO DE CUSTEIO DIRETO NO CÁLCULO DO CUSTO DO PARECER TÉCNICO EMITIDO PELO DEPARTAMENTO DE CÁLCULOS E PERÍCIAS DA ADVOCACIA-GERAL DA UNIÃO

DAVID VICTOR ROCHA DO NASCIMENTO

BRASÍLIA-DF 
UNIVERSIDADE DE BRASÍLIA - UnB

Reitor:

Professor Doutor Ivan Marques de Toledo Camargo

Vice-Reitora:

Professora Doutora Sônia Nair Baó

Decano de Pesquisa e Pós-Graduação:

Professor Doutor Jaime Martins de Santana

Diretor da Faculdade de Economia, Administração e Contabilidade:

Professor Doutor Roberto de Goes Ellery Junior

Chefe do Departamento de Ciências Contábeis e Atuariais:

Professor Doutor José Antônio de França

Coordenador Geral do Programa Multiinstitucional e Inter-regional de Pós Graduação em Ciências Contábeis da UnB, UFPB e UFRN

Professor Doutor Rodrigo de Souza Gonçalves 


\author{
UNIVERSIDADE DE BRASÍLIA (UnB) \\ UNIVERSIDADE FEDERAL DA PARAÍBA (UFPB) \\ UNIVERSIDADE FEDERAL DO RIO GRANDE DO NORTE (UFRN) \\ Programa Multiinstitucional e Inter-Regional de Pós-Graduação em \\ Ciências Contábeis
}

DAVID VICTOR ROCHA DO NASCIMENTO

MENSURANDO CUSTOS NO SERVIÇO PÚBLICO: ESTUDO DE CASO SOBRE A APLICAÇÃO DO MÉTODO DE CUSTEIO DIRETO NO CÁLCULO DO CUSTO DO PARECER TÉCNICO EMITIDO PELO DEPARTAMENTO DE CÁLCULOS E PERÍCIAS DA ADVOCACIA-GERAL DA UNIÃO

Dissertação apresentada como requisito parcial à obtenção do título de Mestre em Ciências Contábeis do Programa Multiinstitucional e InterRegional de Pós-Graduação em Ciências Contábeis da Universidade de Brasília, da Universidade Federal da Paraíba e da Universidade Federal do Rio Grande do Norte.

Área de Concentração:

Linha de pesquisa: Contabilidade Para a Tomada de Decisão.

Orientador: Dr. Bruno Vinícius Ramos Fernandes. 
Nascimento, David Victor Rocha do

Mensurando Custos no Serviço Público: Estudo de Caso sobre a aplicação do Método de Custeio Direto no Cálculo do Custo do Parecer Técnico Emitido pelo Departamento de Cálculos e Perícias da Advocacia-Geral da União. I David Victor Rocha do Nascimento - Brasília, DF, 2015.

$77 \mathrm{f}$.

Orientador: Prof. Dr. Bruno Vinícius Ramos Fernandes.

Dissertação (mestrado) - Universidade de Brasília. Faculdade de Economia, Administração e Ciências Contábeis e Atuariais - FACE. Programa Multiinstitucional e Inter-Regional de Pós-Graduação em Ciências Contábeis (UnB/UFPB/UFRN).

1. Método de Custeio Direto. 2. Sistema de Informações de Custos. 3. Custo do Parecer Econômico-Contábil. 4. Perda de Informação de Custos. I. FERNANDES, Bruno Vinícius Ramos. II. Universidade de Brasília. III. Universidade Federal da Paraíba. IV. Universidade Federal do Rio Grande do Norte. 


\title{
MENSURANDO CUSTOS NO SERVIÇO PÚBLICO: ESTUDO DE CASO SOBRE A APLICAÇÃO DO MÉTODO DE CUSTEIO DIRETO NO CÁLCULO DO CUSTO DO PARECER TÉCNICO EMITIDO PELO DEPARTAMENTO DE CÁLCULOS E PERÍCIAS DA ADVOCACIA-GERAL DA UNIÃO
}

\author{
Dissertação apresentada como requisito parcial à \\ obtenção do título de Mestre em Ciências \\ Contábeis do Programa Multiinstitucional e Inter- \\ Regional de Pós-Graduação em Ciências Contábeis \\ da Universidade de Brasília, da Universidade \\ Federal da Paraíba e da Universidade Federal do Rio \\ Grande do Norte.
}

Comissão Avaliadora:

\section{Prof. Dr. Bruno Vinícius Ramos Fernandes}

Programa Multiinstitucional e Inter-regional de Pós-Graduação em Ciências Contábeis da UnB/UFPB/ UFRN

(Presidente da Banca)

\section{Prof. Dr. César Augusto Tibúrcio Silva}

Programa Multiinstitucional e Inter-regional de Pós-Graduação em Ciências Contábeis da UnB/UFPB/ UFRN

(Membro Examinador Interno)

\section{Prof. Dr. André Nunes}

Programa de Pós-Graduação em Gestão Pública

UnB

(Membro Examinador Externo)

Brasília-DF, 31 de março de 2015. 
Aos meus queridos pais

Vera Lúcia e José Maria (in memorian).

À minha esposa Julie e ao meu filho Miguel. 


\section{AGRADECIMENTOS}

Inicialmente agradeço a Deus pelo dom da vida e pelas oportunidades a mim proporcionadas. Agradeço aos meus pais pela educação que me deram e aos meus irmãos e minha esposa por sempre me incentivarem a estudar.

Agradeço ao meu orientar Dr. Bruno Vinícius Ramos Fernandes pela confiança a mim dispensada, a também ao Professor Dr. César Augusto Tibúrcio Silva pela supervisão na disciplina prática de ensino.

Agradeço a todos os professores que ministraram aula, pois, cada um foi importante para lapidar uma parte do conhecimento bruto por mim detido e acrescentar novos conhecimentos, o que consequentemente me tornou não só um profissional mais capaz de propor soluções e resolver problemas mais também um indivíduo mais atuante na difusão do conhecimento.

Agradeço aos meus chefes no Departamento de Cálculos e Perícias pela anuência e incentivo a mim dispensados para que eu pudesse assistir as aulas do mestrado e também coletasse os dados necessários a elaboração desta pesquisa.

Agradeço aos meus colegas da $25^{\mathrm{a}}$ turma de mestrado, pelo incentivo nas horas difíceis, pelo compartilhamento do conhecimento nos grupos de estudo e pelas verdadeiras amizades formadas nesse ambiente às vezes tão estressante e individualista.

Por fim agradeço a minha esposa pela compreensão na abdicação do tempo de lazer conjunto para dedicação aos meus estudos. 
O sucesso está na nossa capacidade de aprender com o passado, adotar novas ideias e ações no presente e desafiar o futuro.

(Ronald Swift) 


\section{RESUMO}

O trabalho teve como objetivo identificar o custo médio do parecer técnico emitido pelo Departamento de Cálculos - DCP e Perícias da Advocacia-Geral da União - AGU, utilizando para isso o método de custeio direto. Verificou-se, também, o impacto dos custos indiretos sobre esse método de custeio. Além disso buscou-se como objetivos específicos a identificação de elementos que municiassem os gestores do DCP com valores numéricos sobre os trabalhos desempenhados, proporcionando a criação futura de indicadores de eficiência e colaborando na tomada de decisões sobre o DCP. A escolha pelo método direto se deu pela importância recente dada a este método nos trabalhos realizados pelo Governo Federal para a implantação do Sistema de Informações de Custos, e também, por não ter sido encontrado na literatura brasileira trabalhos que abordassem esse método de forma prática. Quanto aos resultados encontrados, verificou-se um custo médio por parecer de $\mathrm{R} \$ 547,25$ com mediana de $\mathrm{R} \$$ 498,53 ambos em valores de janeiro de 2015. Quando se leva em consideração os custos indiretos calculados pelo método absorção rateados pela área ocupada, verificou-se uma perda média de informação no valor dos custos de 20\% no período de janeiro de 2014 a julho de 2014. Quanto a Margem de Contribuição Direta Média - MCDm do parecer técnico, quando classificado por Objeto da Ação, verificou-se que as menores demandas, que representam menos de $10 \%$ dos processos analisados, são responsáveis pelas maiores MCDm por parecer. Já com relação ao Tipo de Cálculo, os resultados mostraram que devem ser priorizados os processos que estão na fase de Embargos (Art. 730 - CPC), pois, eles apresentam a terceira maior MCDm por parecer R\$ 1.618.830,18 além de terem o menor percentual de concordância $15 \%$. Por fím, o método direto não é um método totalmente eficaz para o cálculo de custos de unidades orçamentarias que compartilhem custos indiretos com outras. Porém, a pequena perda de informação é compensada pela facilidade na aplicação do método e consequente rapidez na realização dos cálculos. Portanto, o método de custeio direto provê aos gestores de informações de forma rápida e dentro de um bom nível de confiabilidade, proporcionando ganho de tempo de forma que esses gestores possam tomar as medidas de forma mais célere evitando um maior consumo de gastos públicos desnecessários.

Palavras-Chaves: Método de Custeio Direto; Sistema de Informações de Custos; Custo do Parecer Econômico-Contábil; Perda de Informação de Custos. 


\begin{abstract}
The work aimed to identify the average cost of the technical opinion issued by the Department of Calculations and Expertise - DCP of the General Advocacy of Union, using the direct costing method. Sought, too, check the impact of indirect costs on this costing method. In addition to specific objectives identifying elements that given the managers of DCP, numeric values on the work performed, providing the future creation of efficiency indicators and collaborating in decision-making on the DCP. The choice by the direct method was by the recent importance given to this method in the work carried out by the Federal Government for the implementation of the Cost Integrated Information System, and also because not having been found in Brazilian literature works that approached this method in a practical way. As for the results, it was found an average cost per technical opinion of $\mathrm{R} \$ 547.25$ with $\mathrm{R} \$ 498.53$ of median both in January 2015 values. When you take into account the indirect costs calculated by the absorption method prorated by the area occupied, there has been a loss of information in the average value of the costs of 20\% from January 2014 to July 2014. As the Direct Contribution Margin AverageMCDm of technical opinion for action object, it was found that as a rule the smaller demand, representing less than $10 \%$, are responsible for higher MCDm by opinion. Already in relation to the type of calculation, the results showed that should be prioritized the processes that are at the stage of Embargos (art. 730-CPC), because they have the third highest MCDm by technical opinion of $\mathrm{R} \$ 1,618,830.18$ in addition to having the lowest percentage of $15 \%$ concordance. Finally, the direct method is not an entirely effective method for the calculation of costs of units projects budget files that share indirect costs with other. However, the little information loss is offset by the ease of application of method and resulting speed in carrying out the calculations. Therefore, the direct costing method provides information managers quickly and within a good level of reliability, providing time gain so that these managers can take measures more quickly while avoiding a higher consumption of unnecessary government spending.
\end{abstract}

Key-words: Direct Costing Method; Cost Integrated Information System; Cost of EconomicAccounting Technical Opinion; Loss Costs Information. 


\section{LISTA DE QUADROS}

Quadro 1: Quantidade mensal de pareceres técnicos emitidos de janeiro de 2011 a julho de 2014 ......35

Quadro 2: Valor da mão-de-obra direta no período de janeiro de 2011 a julho de 2014 .......................37

Quadro 3: Valor Mensal dos materiais diretos no período de janeiro de 2011 a julho de 2014...........38

Quadro 4: Resultados das estatísticas descritivas para a variável Valor por Autor..............................58

Quadro 5: Resultados das estatísticas descritivas para a variável Valor por Autor após retirada de valores zerados e de um outlier

Quadro 6: Valores executados por autor, excesso médio apurado por autor, custo médio do parecer por autor e MCDm por autor, distribuídos em 20 classes de igual frequência. 


\section{LISTA DE TABELAS}

Tabela 1: Variáveis disponíveis na Base de Dados Atuação.

Tabela 2: Área e número de servidores por unidade lotada no Edifício Sede I da AGU utilizados para de rateio dos custos indiretos

Tabela 3: Quantidade Pareceres Emitidos por Objeto da Ação, Percentual de Representatividade, Percentual Médio de Concordância e Mediana do Tempo de Elaboração.

Tabela 4: Margem de Contribuição Direta - MCD média e mediana do parecer técnico e MCD média e mediana por autor por parecer todas agregadas por Objeto da Ação.

Tabela 5: Ranking das 10 maiores Margens de Contribuição Direta Média - MCDm por parecer e por quantidade média de autores por parecer.

Tabela 6: Quantidade Pareceres Emitidos por Tipo de Cálculo, Percentual de Representatividade, Percentual Médio de Concordância e Mediana do Tempo de Elaboração. .56

Tabela 7: MCD média e mediana do parecer técnico e MCD média e mediana por autor por parecer todas agregadas por Tipo de Cálculo. 


\section{LISTA DE GRÁFICOS}

Gráfico 1: Evolução do Custo Médio Mensal do Parecer pelo Método Direto em Valores de Janeiro de 2015.

Gráfico 2: Histograma do Custo Médio Mensal do Parecer pelo Método Direto em Valores de Janeiro de 2015 . 


\section{LISTA DE FIGURAS}

Figura 1: Organograma do Departamento de Cálculos e Perícias - DCP. ............................................31

Figura 2: Rotina pela qual o processo passa dentro do DCP para confecção do parecer técnico..........32 


\section{LISTA DE SIGLAS E ABREVIAÇÕES}

$\mathrm{ABC}$

Activity-Based Costing

AGU

Advocacia-Geral da União

CMMO

Custo Médio da Mão de Obra na Execução Fiscal

CNJ

Conselho Nacional de Justiça

DCP

Departamento de Cálculos e Perícias

IPEA

Instituto de Pesquisa Econômica e Aplicada

MCD

Margem de Contribuição Direta

MCDm

Margem de Contribuição Direta média

PEFM

Processo de Execução Fiscal Médio

PGFN

Procuradoria Geral da Fazenda Nacional

PGU

Procuradoria-Geral da União

SERPRO

Serviço Federal de Processamento de Dados

SIAPE

Sistema Integrado de Administração de Recursos Humanos

SIC

Sistema de Informações de Custos

SICAP

Sistema de Cálculos e Perícias da Advocacia-Geral da União

SPSS

Statistical Package for Social Sciences

STN

Secretária do Tesouro Nacional

TDABC

Time-Driven Activity-Based Costing 


\section{SUMÁRIO}

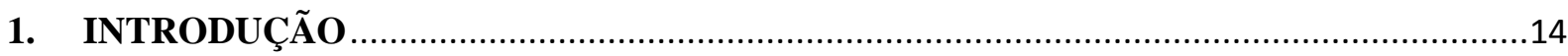

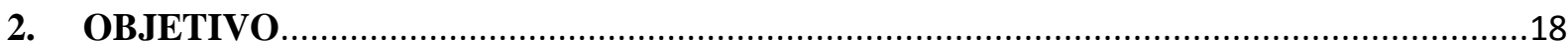

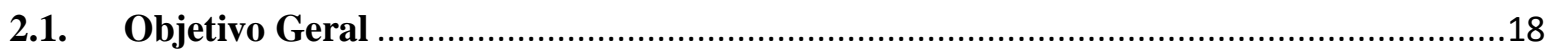

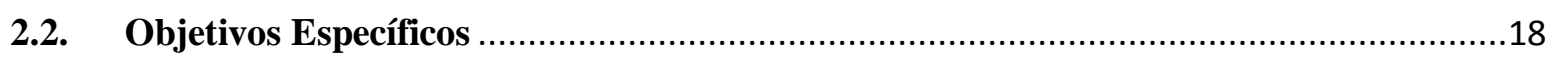

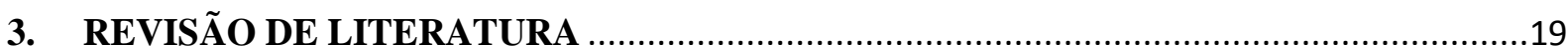

3.1. Trabalhos relacionados ao método de custeio aplicado ao serviço público ....................19

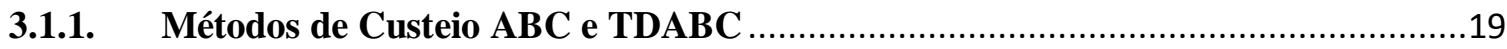

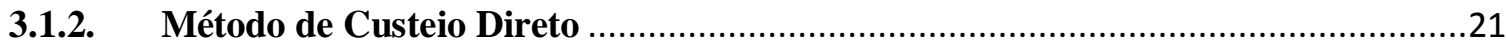

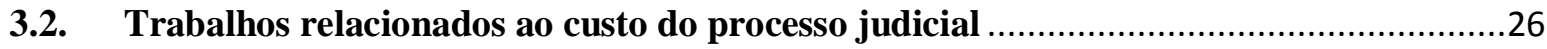

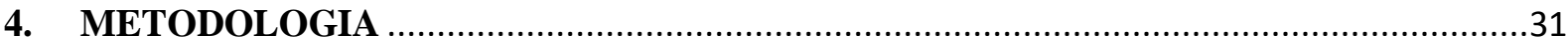

4.1. Rotina do Departamento de Cálculos e Perícias …......................................................

4.2. Amostra do Número do Pareceres ……...................................................................

4.3. Amostra dos Custos com Mão-de-Obra Direta e Materiais Diretos ….........................35

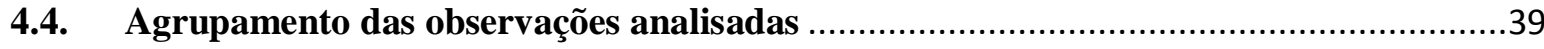

4.4.1. Agrupamento do Tipo de Cálculo e Objeto da Ação...............................................39

4.5. Fórmulas utilizadas na mensuração dos custos do parecer técnico...............................41

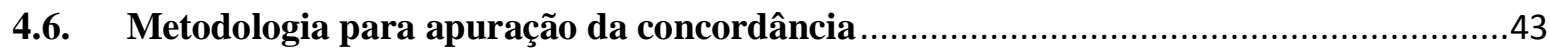

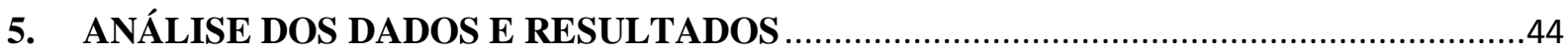

5.1. Valor do Parecer Pelo Método Direto …................................................................44

5.2. Perda de Informação de Custos pela Utilização do Método Direto ...............................46

5.3. Análise do Objeto da Ação e do Tipo de Cálculo .......................................................48

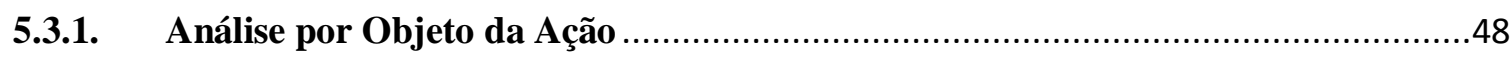

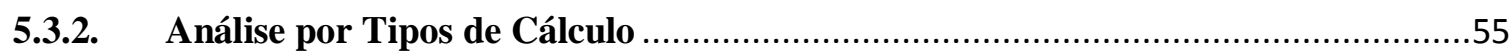

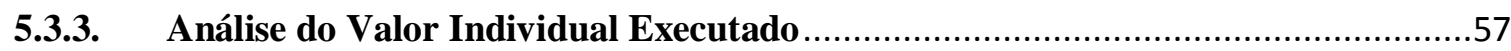

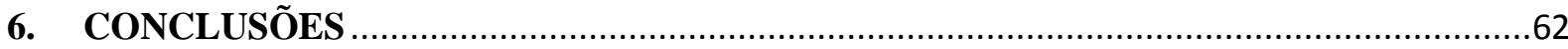

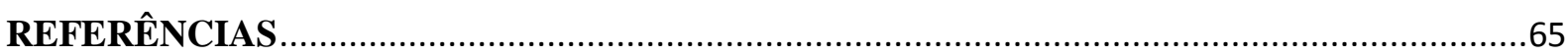

APÊNDICE A - Quantidade mensal de pareceres técnicos emitidos por tipo de parecer de

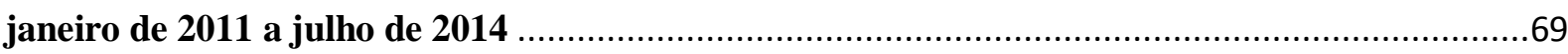

APÊNDICE B - Valor dos materiais diretos e mão-de-obra direta no período de janeiro de 2011

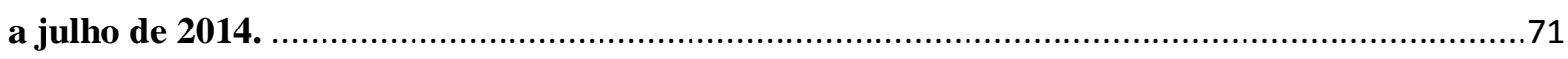

APÊNDICE C - Agrupamento dos Objetos da Ação cadastrados no Atuação .............................72 
APÊNDICE D - Agrupamento dos Tipos de Cálculo cadastrados no Atuação

APÊNDICE E - Custo unitário corrente do parecer técnico pelo método direto e com acréscimo dos custos indiretos rateados em função do metro quadrado. .75

APÊNDICE F - Custos Indiretos do Edifício SEDE I da AGU..................................................77 


\section{INTRODUÇÃO}

A busca pela maior eficiência dos gastos públicos, tem sido um ponto de crescente debate que interliga o meio acadêmico as entidades do Governo. Formas de como mensurar e controlar os gastos públicos aproveitando ao máximo os dados já disponíveis nos sistemas de controle e gerenciamento do Governo, que também sejam de fácil compreensão e manuseio pelos usuários e que tenham baixo custo, estão entre as principais questões debatidas. A partir delas podem ser criadas uma série de indicadores municiando os gestores de informações que os norteiem nas prioridades de alocação dos recursos orçamentários, buscando sempre a melhoria da eficiência dos gastos do Governo, seja no âmbito Federal, Estadual ou Municipal.

Mas esse debate é algo recente, que teve seu movimento, em escala mundial, iniciado nos anos 90, onde surgiu "como uma reação às exigências de preservação da responsabilidade fiscal e às pressões da sociedade por transparência das decisões sobre a utilização dos recursos orçamentários e melhoria da qualidade dos bens e serviços postos à disposição" (REZENDE et al, 2010).

No Brasil esse movimento aparece com mais força a partir da implantação do plano Real, pois, alguns fatores até então existentes contribuíam para o não controle dos gastos de forma eficiente. Segundo Silva et al (2011) os principais fatores eram: a instabilidade econômica, na época de hiperinflação, que propiciava a senhoriagem e; problemas com a capacidade de processamento das informações. Pode-se acrescentar a esses dois problemas a falta de uma lei específica responsabilizando os gestores pelo controle dos gastos públicos, tal como a Lei de Responsabilidade Fiscal passou a fazer a partir de 2000.

Assim, para se alcançar a estabilidade da moeda brasileira a partir de 1994 uma das exigências foi um corte nos gastos públicos de forma que o equilíbrio fiscal fosse alcançado. Em decorrência, o maior controle dos gastos públicos exigiu dos gestores uma maior preocupação com a eficiência desses gastos e consequentemente os gestores se viram na necessidade de apurar os custos dos produtos e serviços ofertados pelo Governo, para assim poder gerar indicadores de eficiência dos gastos.

Em paralelo o Estado estava começando a adotar o modelo gerencial de administração em detrimento do modelo burocrático. De acordo com Borges e Matias (2011) a criação do Ministério da Administração e Reforma do Estado, em 1995, impulsionou o Estado a adotar gradativamente o modelo gerencial de administração que preza pela qualidade dos gastos 
públicos e consequentemente pelo estabelecimento de medidas de desempenho e o controle desses gastos.

Ching et al (2011) afirmam que a tendência de se aplicar no setor público as práticas administrativas do setor privado, buscando uma maior eficácia, eficiência na utilização dos recursos, bem como a avaliação dos resultados obtidos, também foi um fator motivador na implantação do sistema de custos no setor público.

A partir dos anos seguintes a implantação do Plano Real, além da área acadêmica, várias entidades públicas, principalmente as vinculadas ao Governo Federal, passaram a realizar de forma independente, trabalhos que abordavam metodologias e práticas de gerenciamento de custos (SILVA e ROCHA, 2009; CHING et al, 2011; FERNANDES e SLOMSKI, 2011). "No entanto, isso não se deu de maneira orquestrada, concentrada e estruturada pelo governo central até meados de 2008” segundo (BRASIL, 2013: 33).

Verificou-se a partir de Machado (2002) e Fernandes e Slomski (2011) que a preocupação principal dos trabalhos desenvolvidos por entidades públicas pairavam em dois motivos: Como adequar os gastos aos artigos da Lei de Responsabilidade Fiscal e; Como implantar o Modelo de Administração Gerencial através da melhoria da eficiência e eficácia da prestação do serviço público, mensurada através de indicadores de desempenho e qualidade. Essa questão foi abordada no trabalho de Schwengber (2007) que trata de três níveis de avaliação da qualidade do gasto público: 1) sustentabilidade fiscal; 2) impacto dos gastos públicos sobre as variáveis econômicas e sociais; e 3) eficiência do gasto público. O trabalho de Schwengber (2007) se aprofunda no terceiro nível (eficiência do gasto público).

Foi a partir de 2008 que ministérios como o da Fazenda, o da Educação e o do Planejamento, Orçamento e Gestão, montaram uma equipe para desenvolver processos metodológicos comuns "com o objetivo de definir, desenvolver, disseminar e consolidar um modelo de sistema de custos para toda a administração pública brasileira” (BRASIL, 2013: 33).

Com a responsabilidade de coordenar os trabalhos realizados por essa equipe ficou a Secretária do Tesouro Nacional - STN, órgão atualmente responsável pelo Sistema de Informações de Custos - SIC. Segundo Brasil (2013) a valorização da Gestão de Custos é uma tendência mundial, conforme a seguinte afirmação:

A Gestão de Custos no Governo Federal se fixa em uma série de medidas para reforma do Estado Brasileiro. Além disso, o avanço teórico também deve-se em parte a tendência da Contabilidade Pública em adotar as normas internacionais. Nesse sentido, diversos analistas apontam a importância 
administrativa e política da gestão de custos como parte de um processo histórico mais amplo relacionado à eficácia e eficiência da administração governamental.

O Sistema de Informação de Custos está sendo implantando no Governo Federal com base no trabalho desenvolvido por Machado (2002). Neste trabalho, dentre outros parâmetros para implantação do SIC, o autor apresenta o método de custeio direto como a melhor a opção (rápida e barata) para apuração dos custos no serviço público, levando-se em conta os diversos sistemas de informações do Governo já disponíveis.

Diante deste cenário de evolução e aperfeiçoamento do SIC, buscou-se a partir deste trabalho atrelar os conhecimentos acadêmicos à produção de informações úteis à gestão pública, principalmente no que se refere a mensuração dos custos dos serviços públicos.

Assim, este trabalho surgiu a partir de questionamentos como: Qual o custo do trabalho desempenhado pelo Departamento de Cálculos e Perícias (DCP) da Advocacia-Geral da União? Qual o custo do Parecer Técnico emitido? A resposta para primeira questão era estimada a partir do montante que o DCP reconhecia como excesso nas execuções contra a União. Já para segunda questão não havia um estudo sobre ela. Entretanto, tais perguntas, por si só, podiam não se mostrar interessantes para a academia. Buscou-se então atrelar a geração de informação referente ao custo do Parecer Técnico com o método de custeio atualmente utilizado pelo Governo Federal em seu Sistema de Informações de Custos - SIC. Assim, surgiu a seguinte pergunta: Será que o método de custeio direto é realmente a melhor opção para mensuração de custos no serviço público?

A escolha do método direto para mensuração dos custos se deu pela importância recente dada a este método nos trabalhos realizados pelo Governo Federal para a implantação do SIC. Segundo Machado (2002), tal método se mostrou teoricamente eficiente em aproveitar a complexa estrutura já existente no detalhamento do orçamento público como uma fonte de objetos de custos a serem mensurados. Outro fator que contribuiu para escolha do método é que não foi encontrado na literatura brasileira trabalhos acadêmicos que abordassem a aplicação prática da metodologia de custeio direto voltado ao cálculo de serviços públicos, ou seja, trabalhos que detalhassem: fórmulas de apuração dos custos; custos computados; critérios de classificação dos custos como custos diretos; entre outros detalhes metodológicos capazes de proporcionar maior robustez ao método.

O DCP, objeto indireto de estudo deste trabalho, foi criado com a atual denominação pela MP n ${ }^{\circ} 2.180-35$ de 24/08/2001, inserida na Lei no 9.028 de 12/04/1995. Anteriormente ele 
era uma Coordenadoria de Cálculos e Perícias da Procuradoria-Geral da União - PGU, criado pela MP nº 1.984-22, de 27/09/2000, porém, já funcionava como um setor da ProcuradoriaGeral da União, desde 1994. Ele faz parte da estrutura da AGU, conforme Anexo I do Decreto $\mathrm{n}^{\mathrm{o}} 7.392$ de 13 de dezembro de 2010. O DCP tem a missão de "prestar assessoramento técnico e pericial à AGU, com precisão e eficiência, subsidiando a gestão e garantindo segurança à defesa do patrimônio e interesse públicos” DCP (2012). Ele se destaca de outros departamentos da PGU/AGU, por ser um departamento técnico, não jurídico, composto em sua maioria por Contadores. Ele (DCP) possui ramificações em todos os Estados do Brasil, são os Núcleos de Cálculos e Perícias e os Escritórios Avançados de Cálculos e Perícias, que apesar de não estarem subordinados legalmente ao DCP, estão subordinados tecnicamente.

Os dados produzidos por este trabalho visam, além de contribuir com a academia para o melhor entendimento e eficácia do método de custeio direto na apuração dos custos de produtos ou serviços públicos, visa também auxiliar os gestores na construção de indicadores de produtividade, na alocação de recursos humanos, na escolha fundamentada de demanda com prioridade de atendimento, buscando sempre a eficiência dos recursos públicos gastos em obediência aos princípios da economicidade e da razoabilidade.

O trabalho está dividido em 6 partes incluindo esta introdução. No segundo tópico é apresentado o objetivo do trabalho. No Terceiro é feita uma revisão da literatura sobre os métodos de cálculo do custo do processo judicial e sobre outros métodos práticos de custos de serviços públicos. O quarto tópico apresenta a metodologia utilizada no trabalho. No quinto são apresentados os resultados encontrados. Por fim são apresentadas as conclusões do trabalho no sexto tópico. 


\section{OBJETIVO}

\subsection{Objetivo Geral}

Identificar o custo médio do parecer técnico pelo método de custeio direto, bem como verificar a diferença percentual desse método de custeio em relação a não inclusão dos custos indiretos.

\subsection{Objetivos Específicos}

I. Apurar o custo médio mensal do parecer técnico pelo método de custeio direto;

II. Verificar o impacto dos custos indiretos no valor do parecer.

III. Identificar os principais objetos da ação (matéria judicial) a partir das variáveis demanda por pareceres e maiores ganhos médios por parecer;

IV. Identificar os principais tipos de cálculo (fase processual) a partir das variáveis demanda por pareceres e maiores ganhos médios por parecer; 


\section{REVISÃO DE LITERATURA}

\subsection{Trabalhos relacionados ao método de custeio aplicado ao serviço público}

Com relação aos métodos de custeio mais condizentes com a mensuração de custos no serviço público, verificou-se que não há um consenso sobre o tema, porém, durante este trabalho constatou-se a prevalência de trabalhos que abordam o método de custeio ABC (Activit Based Costing). De acordo com Zanievicz et al (2013) no período de 1994 a 2010, 60\% das pesquisas sobre métodos de custeio apresentadas nos Congressos Brasileiros de Custos trataram como tema principal do método de custeio ABC. Söthe et al (2014) verificou, em uma amostra de artigos no período de 2001 a 2010, que 59\% dos artigos publicados sobre custos no setor público também utilizaram o método ABC. Abbas et al (2012), também haviam verificado a importância do método $\mathrm{ABC}$ em trabalhos apresentados nos Congressos Brasileiros de Custos, que tratavam da área pública. Já Martins $(2011$, 37) acrescenta, ainda, o método de custeio variável (direto e indireto) como um dos métodos de custeio que "escapa das críticas efetuadas ao método do custo pleno ou completo que determina a "estocagem" dos custos estruturais", devendo, portanto, ser utilizado no setor público. Mais recentemente a literatura tem abordado o método Time-Driven Activity-Based Costing (TDBAC) apresentado por Kaplan e Anderson (2004) com uma evolução do Método de Custeio ABC com as vantagens de ser flexível, rápido de aplicar e de menor custo.

\subsubsection{Métodos de Custeio ABC e TDABC}

Um defensor do método de custeio ABC aplicado a mensuração dos custos do serviço público é Alonso (1999). Ele defende o custeio ABC, como o método mais indicado devido a variedade e complexidade de atividades existentes nas entidades públicas e consequentemente um melhor controle dos gastos públicos. Alonso (1999) afirma que nos Estados Unidos o ABC é bastante utilizado por Órgãos do Governo como, por exemplo, Receita Federal e as três Forças Armadas.

O método de custeio ABC, também foi empregado no trabalho de Peter et al (2003), que buscam apresentar um sistema de custos para as universidades brasileiras. A vantagem segundo Peter et al (2003), ocorre devido ao fato de que as universidades possuem uma grande diversidade de produtos e serviços e uma elevada estrutura de custos fixos. Eles também sugerem a criação de um "Dicionário de Atividades" como uma forma de padronização dos critérios de rateio obtidos pelo $\mathrm{ABC}$. 
Uma derivação do método de $\mathrm{ABC}$ é o Time-Driven Activity-Based Costing - TDABC. O TDABC segundo Pernot et al (2007) é um método derivado do ABC onde Kaplan e Anderson buscaram tornar a apuração dos custos mais fácil e barata sem perder os benefícios do método ABC. Ainda, segundo Pernot et al (2007) a mais importante característica do TDABC está na simplicidade, pois, somente dois parâmetros precisam ser estimados: o tempo consumido para realizar as atividades relacionadas com o objeto de custo e; o custo por unidade de tempo.

Uma aplicação prática do TDABC foi o trabalho de Silva et al (2011). O trabalho teve como objetivo a elaboração de metodologia que permitisse calcular os custos dos serviços prestados pelo Sistema Nacional de Emprego - SINE e posteriormente o cálculo dos custos operacionais de implantação e manutenção dos postos do SINE, auxiliando na obtenção de parâmetros que auxiliassem o Ministério do Trabalho e Emprego nos convênios celebrados no âmbito do SINE.

Para atingir o objetivo, Silva et al (2011) estabeleceram 6 etapas a serem percorridas. A primeira era a determinação do custo da capacidade do posto do SINE, ou seja, o custo dos recursos utilizados para operacionalizar um posto: empregados, imóveis, utilidades, equipamentos e outros custos. A segunda etapa foi a do cálculo da capacidade do posto, obtido a partir da fórmula de capacidade teórica que é o produto das horas trabalhadas por dia vezes os dias trabalhados por mês vezes o número de funcionários de um posto. Sobre a capacidade teórica foi aplicado o percentual de $80 \%$, já que estudos indicaram que há um percentual de perda normal do tempo trabalhado. O resultado obtido foi chamado de capacidade prática. A terceira etapa foi o cálculo do custo da capacidade prática que foi dado pelo resultado do custo dos recursos usados dividido pela capacidade prática. Os autores chegaram a um resultado de $\mathrm{R} \$ 0,48$ por minuto.

A quarta etapa percorrida por Silva et al (2011) foi a determinação das atividades executadas em um posto do SINE, resultando num total de 14, para a pesquisa. Eles ressaltaram que algumas subtarefas foram deixadas de lado para minimizar possíveis erros na mensuração. A quinta etapa foi a determinação do tempo das atividades pelo método da observação. Assim os pesquisadores realizaram diversas observações das diferentes rotinas existentes nos diferentes postos do SINE e apuraram o tempo e a dispersão de cada atividade predeterminada. A sexta e última etapa foi unir o custo por minuto vezes o tempo médio gasto em cada atividade vezes o número de atividades que é desempenhado em cada período que se deseja obter o custo. 
Assim o trabalho de Silva et al (2011) mostrou resultados satisfatórios e proporcionando parâmetros aos gestores do Ministério do Trabalho e Emprego. O trabalho pelo seu grande detalhamento é uma referência importante para outros que visem utilizar o método TDABC.

\subsubsection{Método de Custeio Direto}

Outro método de custeio para aplicação na mensuração de custos dos serviços públicos é o método de custeio Direto. É interessante ressaltar que este método por diversas vezes é tratado como sinônimo do método de custeio Variável, o que está errado, pois, como será detalhado adiante o custeio variável não leva em conta os custos fixos que são diretamente atribuídos ao objeto de custo.

Para melhor visualizar a diferença entre esses dois métodos (Variável e Direto), alguns conceitos devem ser relembrados. A contabilidade de custos, divide os gastos em custos e despesas. Os custos estão relacionados a utilização dos fatores de produção, ou seja, no consumo de materiais diretos e indiretos, mão-de-obra direta e indireta, e outros gastos que sejam consumidos no processo de fabricação de produtos ou execução de serviços. Já as despesas são os gastos incorridos de forma direta ou indireta para a produção de receita. (MORGAN e ROSA, 2006; MARTINS, 2003).

Ressalta-se que o fato do custo ser direto ou indireto, depende do referencial, ou seja, do objeto de custo escolhido (MAHER, 2001, p. 70). O mesmo pode-se atribuir aos custos fixo ou variável que dependem do volume produzido do objeto de custo escolhido. Segundo Garrison et al (2013, p. 44), objeto de custo é qualquer coisa sobre a qual se deseje obter dados de custo, por exemplo, produtos, clientes, ordens de produção e subunidades organizacionais. Esses autores, conceituam custo direto como aquele que pode ser fácil e convenientemente associado a um objeto de custo especificado, já o custo indireto não pode ser fácil e convenientemente associado a um objeto de custo especificado. Um exemplo de custo indireto é o denominado custo comum, que é um custo incorrido por vários objetos de custos ao mesmo tempo, não podendo ser atrelado a um objeto de custo de forma individual. (GARRISON et al, 2013, p. 44).

Assim, de acordo com Garrison et al 2013, o método de custeio Variável incorpora apenas os custos de produção que variam conforme o nível de produção (volume de produção). Isso normalmente inclui os materiais diretos, mão-de-obra direta e a porção variável dos custos indiretos de produção. Essa porção indireta dos custos de produção não entra no método de custeio Direto. 
Zimmerman (2010, p. 47) afirma que os Custos Diretos de um produto ou serviço são aqueles itens que são facilmente atribuídos para o produto ou serviço. Ele afirma também que a mão-de-obra direta e o material direto são custos diretos e cita como exemplo um empregado que produz um produto específico é classificado como mão-de-obra direta, entretanto se este empregado está inativo devido à quebra da máquina que utilizava, neste tempo inativo ele é classificado como mão-de-obra indireta. O autor ressalta, ainda, a importância do custobenefício de se apurar um determinado custo direto, pois, caso não valha apena tal custo pode ser classificado com indireto. Além disso, ele afirma que os custos diretos são geralmente variáveis, mas tais custos também podem ser fixos. Assim, nunca pode-se assumir que todos os custos diretos são variáveis e que todos os custos gerais são custos fixos (ZIMMERMAN, 2010).

Vartanian (2000, p. 72) apud Collatto e Reginato, (2005) afirma que o custeio variável difere do direto em relação aos custos fixos que possam ser diretamente identificados como objeto de custeio, compondo desta forma o custo direto. Entretanto, tais custos fixos jamais poderiam ser computados no custeio variável.

Diante desses conceitos, Collatto e Reginato, (2005) verificaram que o custeio direto leva ao objeto de custeio, além dos custos e despesas variáveis, os custos fixos que o são próprios. Elas afirmam, ainda que atualmente as empresas contratam seus empregados por tempo (trabalhado ou não) e não por produção, de forma que a mão-de-obra é caracterizada como custo fixo e direto nos casos que puder ser associado facilmente ao objeto de custos. Outro autor que confirma esse entendimento é Zimmerman (2010, p. 47). Ele cita que se a empresa fixou sua força de trabalho e não ajusta a quantidade de trabalho as mudanças de saída da produção, então a mão de obra direta é um custo fixo, isso ocorre geralmente quando as empresas têm acordos com os sindicatos de trabalhadores para não demitir funcionários em períodos de baixa produção.

É exatamente isso que ocorre com os serviços públicos, pois, em sua grande maioria, os empregados/servidores públicos obtêm suas remunerações mensais independentemente do volume de produção, o que caracteriza a mão-de-obra como um custo fixo para o Governo. Tal custo fixo de mão-de-obra, pode na maioria dos casos, ser alocado diretamente ao custo da prestação do serviço público desempenhado pelo empregado/servidor público. 
Machado (2002), Holanda, Weltman e Guimarães (2010), Machado e Holanda (2010), Santos (2011) e Martins (2011) também defendem o custeio direto como método mais indicado para mensuração de custos dos serviços públicos.

O trabalho de Machado (2002) teve como objetivo principal "explicitar um conjunto de diretrizes para a construção de um sistema de informação de custo integrado sistêmica e conceitualmente ao orçamento público e à contabilidade governamental, que atenda às exigências legais e auxilie na avaliação" da eficiência, da eficácia e da efetividade dos gestores no uso dos recursos públicos (MACHADO, 2002).

Machado (2002) apresenta três pontos como pilares para o desenvolvimento do trabalho. O primeiro reside do fato de que os objetos de custos seriam identificados a partir das classificações orçamentárias já existentes. O segundo trata da interligação entre a contabilidade governamental e o sistema de custos a partir do conceito de despesas orçamentárias liquidadas. E por último o autor cita o método de custeio direto para apuração dos custos.

Assim, Machado (2002) conceitua o custeio direto como "aquele que apropria os custos diretos, quer fixos, quer variáveis, a quaisquer objetos de custo, sejam eles produtos, lotes de produtos, centros de responsabilidade, centros de resultado, sejam quaisquer outros de interesse do gestor" (MACHADO, 2002, 145). Ele frisa a importância de ressaltar que o custeio direto não sofre qualquer tipo de rateio

Para reforçar a importância do método de custeio direto, Machado (2002), posteriormente ratificado por Machado e Holanda (2010), apresentou três argumentos a favor da aplicação do custeio direto no setor público.

O primeiro é que o custeio direto está imune a critérios arbitrários de rateio permitindo uma análise mais objetiva do desempenho dos gestores e das políticas públicas.

É interessante ressaltar que a expressão "imune a critérios arbitrários de rateio" é bastante forte, pois, o gestor/pesquisador ao classificar o custo como direto ou indireto, já se utiliza de um critério arbitrário de classificação que é custo-benefício de ter a informação de determinado item de maneira isolada.

O segundo é que esse método está entranhado no sistema de planejamento, orçamento e contabilização da execução orçamentária. Eles demonstram esse argumento da seguinte forma: 
- a ação do governo - projetos e atividades — é a categoria utilizada para a programação das despesas orçamentárias;

- os recursos necessários à execução dessas ações, classificados conforme sua natureza econômica, são estimados e detalhados por projetos e atividades. Dessa forma, os recursos a serem consumidos associam-se diretamente com as atividades a serem executadas;

- a ação de governo se desenvolve em um determinado espaço organizacional perfeitamente identificável sendo, portanto, possível acumular diretamente as despesas executadas por atividades/projetos, por órgãos, por gerentes de programas ou ordenadores de despesas. Como os projetos/atividades devem cumprir uma função de governo, são também facilmente identificáveis com a classificação funcional;

- o modelo de acumulação direta das despesas orçamentárias pode ser transformado em modelo de acumulação do custo do período ou da ordem, uma vez feitos os ajustes das despesas orçamentárias liquidadas e dos investimentos (principalmente consumo dos estoques), conforme se discutiu anteriormente nos ajustes conceituais contábeis.

No terceiro argumento Machado (2002) e Machado e Holanda (2010) afirmam que "a relação custo-benefício da informação, embora difícil de ser quantificada, é claramente favorável ao método do custeio direto" (MACHADO, 2002, 149). Isso, segundo os mesmos autores, decorre da facilidade, celeridade e baixo custo da implantação, bem como da baixa complexidade do treinamento de funcionários e gestores, devido ao fácil entendimento e aplicação prática do método.

O trabalho de Holanda, Weltman e Guimarães (2010), apresenta os fatos históricos e técnicos que desencadearam na elaboração do Sistema de Informações de Custos do Governo Federal. Dentre os vários pontos citados é de maior interesse para esse trabalho a justificativa que eles apresentam para a utilização método de custeio direto. Em entrevista com Nelson Machado, secretário executivo do Ministério da Fazenda, em relação ao sistema de custeio que seriam utilizados, ele afirmou:

...há uma discussão acadêmica clássica aqui: gestão estratégica de custo associada a activity based costing. Então, custo por atividade; você tem que desenhar as atividades, ver os direcionadores de custos... etc. Bom. Se você vai e coloca essa formulação teórica como o teu norte, você vai gastar rios de tinta e rios de dinheiro para definição das atividades, do caderno de atividade... É como diz o Brimson: "as atividades não têm fim", porque você pode ir quebrando todas as atividades até onde você quiser, até o mínimo detalhe da atividade. Bom. Quando você terminar de fazer isso terminou o governo; e vai ter outro camarada que vai ser o secretário da Fazenda, e provavelmente, talvez, ele terá uma outra ideia que não é aquela...(HOLLANDA, WELTMAN e GUIMARÃES, 2010, 70) 
Holanda, Weltman e Guimarães (2010), afirma que isso não quer dizer que o método $\mathrm{ABC}$ não sirva como medida, mas que nesta primeira fase de consolidação de teorias e sistemas já estruturados para implantação do SIC, quanto menos subjetivismo tivesse melhor e mais rápido o sistema seria implantado.

Assim, apesar de Holanda, Weltman e Guimarães (2010) não citarem expressamente o conceito de custeio direto, o que se entendeu do artigo é que o Método de Custeio Direto refletiria diretamente os gastos de um determinado objeto de custo, desde o nível mais agregado até o nível mais detalhado, levando-se em conta as unidades e ou subunidades orçamentárias já existentes. Os objetos de custos já existiriam e estariam detalhados nos vários níveis do orçamento público.

O artigo de Santos (2011) teve como objetivo apresentar o Sistema de Informações de Custos do Governo Federal. Ele recapitula os conceitos de custeio direto trazidos por Machado (2002) e Holanda, Weltman e Guimarães (2010) e apresenta o conceito de margem de contribuição direta: é a diferença entre a receita obtida pela venda de um produto ou prestação de um serviço e os custos diretos do produto ou serviço (SANTOS, 2011, 6).

Assim a margem de contribuição direta será, neste trabalho, a diferença entre a receita obtida na elaboração do parecer técnico menos o custo do parecer técnico. A receita obtida pela prestação do serviço será a o excesso apurado em cada parecer técnico. Isso será detalhado no item 4.5.

O trabalho de Martins (2011) tem como objetivo principal apresentar diretrizes para elaboração de indicadores de custos no Governo Federal. Ele inicia o trabalho apresentando o histórico legal da exigibilidade do controle de custos no Brasil, em seguida faz uma breve avaliação da formatação dos dados disponíveis nos sistemas de controle do Governo Federal e por fim apresenta a proposta de diretrizes. Martins (2011) afirma que no setor público deve ser utilizado o critério dos custos parciais em detrimento ao custeio pleno e cita o custo variável direto e indireto como uma solução. Ele não faz menção direta a um conceito de custeio direto, apenas afirma que a utilização do método dos custos diretos é decorrente da deficiência de outros métodos de custos completos, que envolvem critérios de rateio, em proporcionar medidas precisas para subsidiar decisões.

Abbas et al (2012) cita que os métodos tradicionais: custeio por absorção; método das seções homogêneas e; o custeio variável, recebem muitas críticas pelo fato de que atualmente o mercado, cada vez mais competitivo, faz com que as empresas minimizem ao máximo os 
custos fixos de forma que os custos variáveis passem a ser a maior parte dos custos dos produtos ou serviços. Desta forma, segundo Abbas et al (2012) os métodos tradicionais foram "criados para organizações em que a maior parte dos custos era composta pelos materiais diretos e pela mão de obra direta". Na década de 1990, Rocha (1992), verificou que no setor terciário da economia (prestação de serviços) os gastos com salários e encargos sociais chegavam a 70\% dos custos totais das empresas. Já Magalhães et al (2010), afirmam que dentre os custos das universidades federais brasileiras, o custo com pessoal e encargos sociais varia entre $80 \%$ a 90\% dos custos dessas instituições.

Assim, analogamente não é incorreto afirmar que o método de custeio direto é um método que se mostra adequado ao cálculo dos custos se na entidade na qual se deseje obter o custo, de algum objeto de custo, predomine na composição os custos de materiais diretos e mão de obra direta.

\subsection{Trabalhos relacionados ao custo do processo judicial}

Na revisão literária, o primeiro trabalho identificado que se propôs a calcular os custos do sistema judiciário e consequentemente dos processos judiciais, foi o livro de Kakalik e Ross (1983). O livro de Kakalik e Ross (1983) é o objeto do artigo de Brunet (1985) que buscou sintetizar o livro, tecer algumas críticas que dizem respeito a não inclusão dos possíveis motivos dos resultados obtidos, e elogios a metodologia trazida para apuração dos custos.

Kakalik e Ross (1983) estabeleceram inicialmente uma metodologia com cinco passos para coletar os dados necessários ao cálculo do custo do processo. Os passos foram: 1) determinaram os tipos de atividades conduzidas para o andamentos dos processos; 2) obtiveram informações sobre a quantidade de tempo gasta por cada servidor público para completar cada atividade do processo; 3 ) obtiveram informações sobre o total de gastos públicos por processos, relacionando o tempo de trabalho em minutos do juiz com todos outros servidores que atuam no andamento do processo e também com itens não pessoais (por exemplo, material de escritório e limpeza); 4) estimaram o custo por processo através da multiplicação da quantidade de minutos que o juiz gasta em cada processo vezes o custo total por minuto do juiz; e 5) estimaram o total de gastos em todo o país através da multiplicação do número de casos registrados anualmente vezes a média do custo do governo por caso registrado.

Para seleção da amostra os autores escolheram dentre todos os estados dos Estados Unidos, as Varas Judiciais (courts) dos estados que possuíam bom sistema de controle do tempo que o processo judicial levava em cada etapa. Os estados foram Califórnia, Flórida, Washington e o U.S. District (Washington capital). Kakalik e Ross (1983) categorizaram a amostra em sete 
diferentes tipos de processo: 1) relações domésticas; 2) saúde mental; 3) sucessões e tutela; 4) direitos de propriedade e condenações; 5) delitos; 6) contratos e outras reclamações civis; e 7) outras petições civis.

Por fim, Kakalik e Ross (1983) verificaram que a média do custo do processo nos 3 estados foi de U\$S 213,00 em valores de 1982, já para a os processos registrado no U.S. District o custo médio ficou em torno de U\$S 1.500,00 em valores de 1982. Os maiores custos foram atribuídos aos processos que tratavam dos itens 6 e 7 do parágrafo anterior, seguido do item 1 .

Santos et al (2005) em estudo desenvolvido para o Ministério da Justiça de Portugal, cujo objetivo era "construção de indicadores de distribuição processual e de avaliação e de projeção do volume de trabalho dos juízes", apresentaram 3 métodos para cálculo do tempo médio para conclusão de um processo. Os métodos são: Weighted Caseload Method; Delphi Method e; Normative Method.

O primeiro método, segundo Santos et al (2005) exigia a execução das seguintes fases: 1) Seleção de uma amostra de processos; 2) Identificação dos atos ocorridos em um determinado processo; 3) Registro da frequência desses atos; 4) Registro do tempo que o juiz necessita para realizar cada ato; 5) Multiplicação da frequência dos atos pelo tempo de cada ato e posterior soma dos diversos atos ocorridos no processo. O segundo método (Delphi Method) difere do primeiro apenas na forma de coleta das fases 3 e 4, pois, no primeiro método, tais dados são coletados por um observador, já no segundo há uma entrevista com o funcionário ou juiz responsável pelo ato que informa o tempo médio do respectivo ato processual. O terceiro método (Normative Method) compara tribunais com atribuições semelhantes a partir de fatores como: jurisdição do tribunal e população atendida. Identificado a equivalência dos fatores para os tribunais, divide-se tal fator pelo número de juízes.

O primeiro trabalho encontrado na literatura nacional que trata diretamente do modelo de custeio aplicado ao custo dos processos judiciais é a dissertação de Remígio (2002). Remígio (2002), em sua revisão bibliográfica, não identificou trabalhos nacionais ou internacionais que abordassem um modelo de custeio específico para apuração do custo de processo judicial.

De forma objetiva, Remígio (2002) discorre sobre modelos de financiamento do setor públicos, sobre a questão tributária relacionada às taxas de custas judicias, sobre os aspectos legais da aplicação de custos no setor público e sobre as características de um sistema de apuração dos custos dos processos judiciais. Ele baseou-se em Alonso (1999) para apresentar o método de custeio ABC como o melhor para apuração do custo do processo judicial, pois, reduz a subjetividade na escolha dos critérios de rateio dos custos indiretos. 
Remígio (2002) apresenta uma série de contas orçamentárias que ele atribuiu como norteadoras para apuração dos custos de processos judiciais. Ele ainda, aborda qual o nível de detalhamento das contas que seria ideal para se coletar a informação e também como fazer o tratamento das contas, ou seja, retirar de algumas contas agregadas outras que na prática estariam inflando os dados e consequentemente a apuração dos custos.

Utilizando o método ABC, Remígio (2002) identificou 5 atividades principais para rateio dos custos indiretos. São elas: distribuição; desenvolvimento nas varas; central de mandados; contadoria judicial; e outras atividades. Este autor não chegou a apurar os custos efetivamente incorridos, pois, seu objetivo pairava na caracterização de um modelo destinado à produção de informações sobre os custos dos processos judiciais que tramitam no âmbito da Justiça Federal (REMÍGIO; 2002).

Outro trabalho a ser citado foi o realizado pelo IPEA - Instituto de Pesquisa Econômica Aplicada em um acordo de cooperação técnica com o CNJ - Conselho Nacional de Justiça, com o objetivo de mensurar o custo unitário do processo de execução fiscal da Justiça Federal. No trabalho o IPEA "procurou inovar metodologicamente, combinando os métodos Carga de Trabalho Ponderada (Weighted Caseload Method) e Custeio Baseado em Atividades" (IPEA, 2011b).

A escolha do processo de execução fiscal, foi devido ao maior peso relativo na carga de trabalho do Poder Judiciário: 34,6\% do estoque de ações judiciais em tramitação na Justiça Federal - JF de $1^{\circ}$ Grau, no ano de 2009. O IPEA utilizou como amostra 1.510 processos com baixa definitiva na Justiça Federal no ano de 2009, localizados em 184 varas federais diferentes, em 124 cidades, durante o período de julho a setembro de 2010. (IPEA, 2011b).

Para definição dos vetores de custo da execução fiscal o IPEA construiu uma equação denominada processo de execução fiscal médio - PEFM. Esta fórmula é a representação média de um processo de execução fiscal na Justiça Federal, ou seja, as fases processuais pelas quais o processo passa, o tempo médio em cada fase e a frequência. (IPEA, 2011a).

Assim a fórmula do PEFM elaborada pelo IPEA é:

$$
\begin{gathered}
\boldsymbol{P E F M}=\Delta t w z(a)+\Delta t w z(b)+\Delta t w z(c)+\Delta t w z(d)+\Delta t w z(e)+\Delta t w z(f)+ \\
\Delta t w z(g)+\Delta t w z(h)+\Delta t w z(i)+\Delta t w z(j)+\Delta t w z(k)+\Delta t w z(l)+ \\
\Delta t w z(m)+\Delta t w z(n)+\Delta t w z(o)
\end{gathered}
$$

Em que:

$\Delta \mathrm{t}=$ intervalo de tempo médio medido em minutos;

$\mathrm{w}=$ frequência média de determinada etapa; 
$\mathrm{z}=$ valor médio por minuto da remuneração dos servidores envolvidos na etapa;

(a) = autuação;

(b) = despacho inicial;

(c) = citação pelo correio (AR);

(d) = citação por oficial de justiça;

(e) = citação por edital;

(f ) = mandado de penhora e avaliação;

(g) = leilão;

(h) = vista ao exequente;

(i) = objeção de pré-executividade;

(j) = embargo do devedor ou de terceiros;

$(\mathrm{k})=$ agravo;

(l) = apelação;

$(\mathrm{m})$ = recurso especial ou extraordinário;

(n) = sentença;

(o) = baixa definitiva

Pelo primeiro método (Carga de Trabalho Ponderada), o IPEA utilizou os dados orçamentários da JF de $1^{\circ}$ Grau, e verificou que o custo médio total do processo no ano de 2009 foi de $\mathrm{R} \$ 1,58 /$ dia, resultando no custo médio total provável do PEFM de R\$4.685,39. Neste método, fatores, como complexidade das rotinas e qualidade da mão de obra empregada, não podem ser objeto de detalhamento (IPEA, 2011a).

Visando separar o tempo perdido com o processo parado (aguardando o decurso de prazo processual, ou retido pelo congestionamento do sistema) o IPEA utilizou um segundo método derivado do método $\mathrm{ABC}$. Ele criou um novo indicador chamado de custo médio da mão de obra na execução fiscal - CMMO, "a partir da conversão do orçamento de pessoal executado pela Justiça Federal de primeiro grau no exercício financeiro de 2009 no orçamento por minuto trabalhado, ponderado com base na participação relativa de magistrados, servidores e estagiários no processamento dos executivos fiscais" (IPEA, 2011a, 26).

Como consequência foram obtidos os seguintes coeficientes: R\$ 4,41/minuto da MO mão de obra de um magistrado; $\mathrm{R}$ \$1,93/minuto da MO de um serventuário; e $\mathrm{R} \$$ 0,04/minuto da MO de um estagiário. Ele considerou a proporcionalidade do trabalho envolvido como: 6,8\% para magistrados; 89,7\% para servidores; e 3,6\% para estagiários. O restante dos custos, servidores terceirizados, água, luz, telefone, correio, papel e capital (prédios e equipamentos) 
foram considerados como custos fixos. O custo fixo médio por processo/ano na $\mathrm{JF}$ de $1^{\circ} \mathrm{Grau}$ foi de R \$ 70,68. Considerando o tempo médio de tramitação do PEFM, de 8 anos, 2 meses e 9 dias, o custo fixo de um processo executivo fiscal é de $\mathrm{R} \$ 541,11$. Por fim o IPEA apurou o custo médio provável do PEFM em R \$ 1.854,23. (IPEA, 2011a).

O IPEA afirma que a diferença apurada entre os métodos ABC e o da Carga de Trabalho Ponderada, explica-se pelo custo agregado e da mão de obra indireta (outras atividades desempenhadas pelo Poder Judiciário e que não estão diretamente relacionadas ao cumprimento de sua atividade fim, ou não são mensuráveis de modo individualizável). Ele também ressalta que deve-se levar em conta as perdas de eficiência normais que envolvem qualquer trabalho humano. Se um servidor responsável pela autuação trabalha 6 horas por dia, e o tempo médio necessário para autuar um processo é de 20,8 minutos, não se deve supor que este deva autuar em média 17,3 processos por dia. Afinal, um servidor não é uma máquina. (IPEA, 2011b).

O IPEA (2011c) aproveitando os dados obtidos na assessoria técnica ao CNJ, realizou um estudo para a PGFN - Procuradoria Geral da Fazenda Nacional, objetivando mensurar o tempo e o custo do processo de execução fiscal promovido pela PGFN. Utilizando do método da carga de trabalho ponderada o IPEA (2011c) verificou que o PEFM da PGFN dura em média 9 anos, 9 meses e 16 dias e tem um custo médio provável é de R \$ 5.606,67. O IPEA (2011c), ainda, verificou que levando-se em conta que a probabilidade de recuperação integral dos créditos apurada foi de $25,8 \%$, então o ponto de equilíbrio a partir do qual é economicamente justificável promover a execução judicial é de R \$21.731,35 (IPEA, 2011c).

É importante ressaltar que o valor de R \$21.731,35 encontrado pelo IPEA (2011c), da forma como foi apresentado, torna temerária a sua utilização como um ponto de equilíbrio, pois, não foi calculado a participação percentual de processos de execução fiscal com valores abaixo de R \$21.731,35, no total de processos executados pela PGFN. Tal percentual é importante para se ter de fato uma real dimensão do montante a ser "anistiado". A utilização de tal valor como uma referência absoluta, pode proporcionar um efeito colateral que seria um aumento no descumprimento da lei por indivíduos e/ou entidades em montantes que estivessem dentro da margem de inviabilidade econômica do processo de execução fiscal. 


\section{METODOLOGIA}

A metodologia utilizada neste trabalho é uma adaptação das metodologias utilizadas por Kakalic e Ross (2013) e pelo IPEA (2011) com relação ao cálculo do custo do processo judicial, porém, levando-se em conta apenas o custeio direto conforme defendido por Machado (2002), Holanda, Weltman e Guimarães (2010), Machado e Holanda (2010), Santos (2011) e Martins (2011).

\subsection{Rotina do Departamento de Cálculos e Perícias}

Inicialmente, antes de abordamos a técnica metodológica é necessário apresentar a rotina do DCP. O DCP é organizado hierarquicamente conforme o organograma apresentado na Figura 1.

Figura 1: Organograma do Departamento de Cálculos e Perícias - DCP.

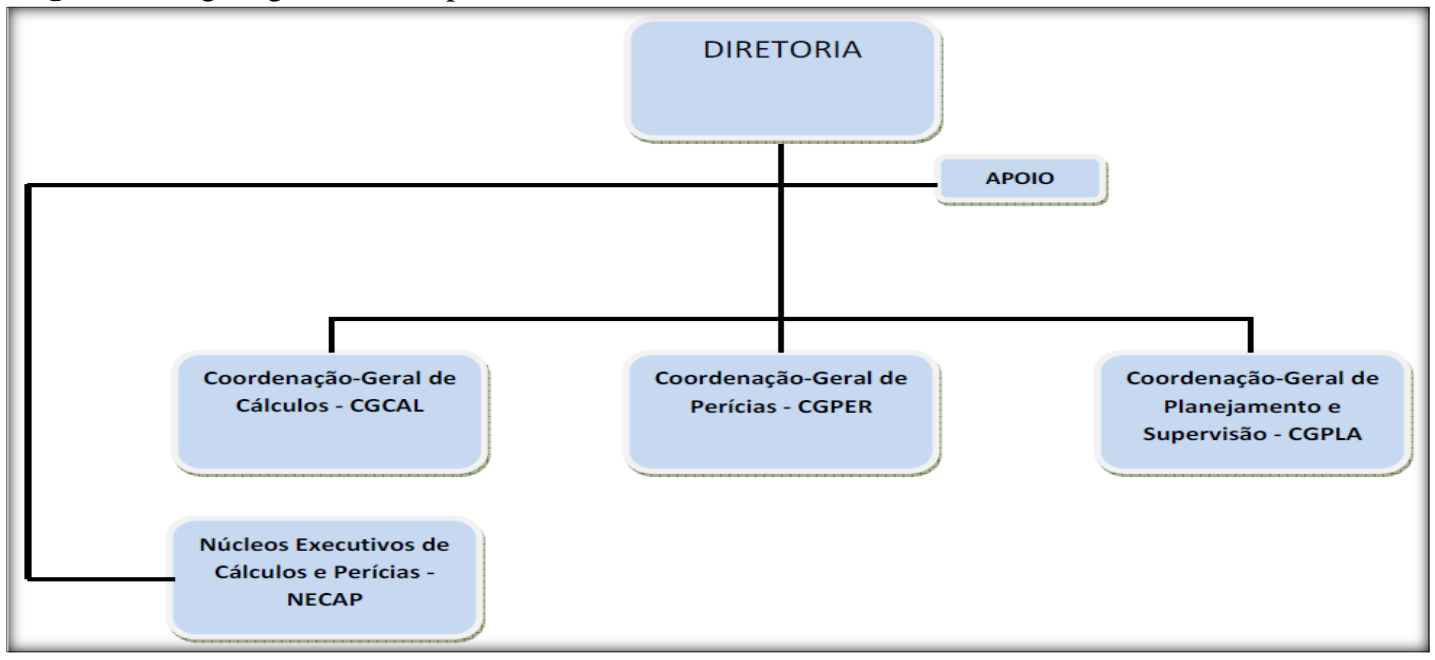

Fonte: Retirado da página do DCP disponível na intranet da AGU.

O DCP tem como clientes os Advogados da União e Procuradores Federais que demandam em sua grande maioria a opinião técnica do DCP sobre um determinado cálculo judicial ou extrajudicial, simulações de impacto financeiro, parcelamento de débitos, entre outros serviços. O atendimento é realizado através da emissão de um parecer técnico, que irá servir como subsídio, prova técnica, para o fim solicitado.

A rotina ordinária do processo dentro do DCP está apresentada na Figura 2. A primeira etapa, é quando a demanda (por exemplo solicitação de análise de conta) chega ao DCP e é registrada no Apoio (Protocolo do DCP). O Apoio é o setor responsável pelo cadastramento inicial do processo no sistema do DCP, fazendo em seguida a triagem por matéria para distribuição aos chefes competentes. 
A segunda etapa ocorre quando o processo chega à chefia responsável pela matéria que realiza uma nova triagem e faz a distribuição para o analista/técnico que irá elaborar o parecer. Nesta etapa, pode ocorrer também a distribuição para outra chefia imediatamente inferior ou equivalente em caso de triagem prévia errada.

$\mathrm{Na}$ terceira etapa o analista/técnico que recebe o processo verifica a prioridade em relação a outros processos que possui para analisar e realiza a análise. A terceira também pode ser semelhante a segunda caso o processo tenha passado por chefia superior antes da chefia responsável pela matéria.

A quarta etapa só ocorre quando o processo passa por duas chefias antes de chegar a mesa do técnico para análise. Esse caso ocorre com pouca frequência, mas quando não identificado de imediato pode gerar atrasos no cumprimento do prazo dado pelo demandante.

Finalizado o parecer técnico, ele volta para a chefia imediatamente superior, ou nas exceções, para outra que ficar acordado. Ele passa por uma breve revisão, onde podem ser solicitadas alterações para que posteriormente seja liberado para o Apoio, que numera o parecer e o devolve ao demandante. No caso de processos de maior frequência e menor complexidade, eles podem ser entregues diretamente ao Apoio, sem a revisão da chefia responsável.

Figura 2: Rotina pela qual o processo passa dentro do DCP para confecção do parecer técnico.

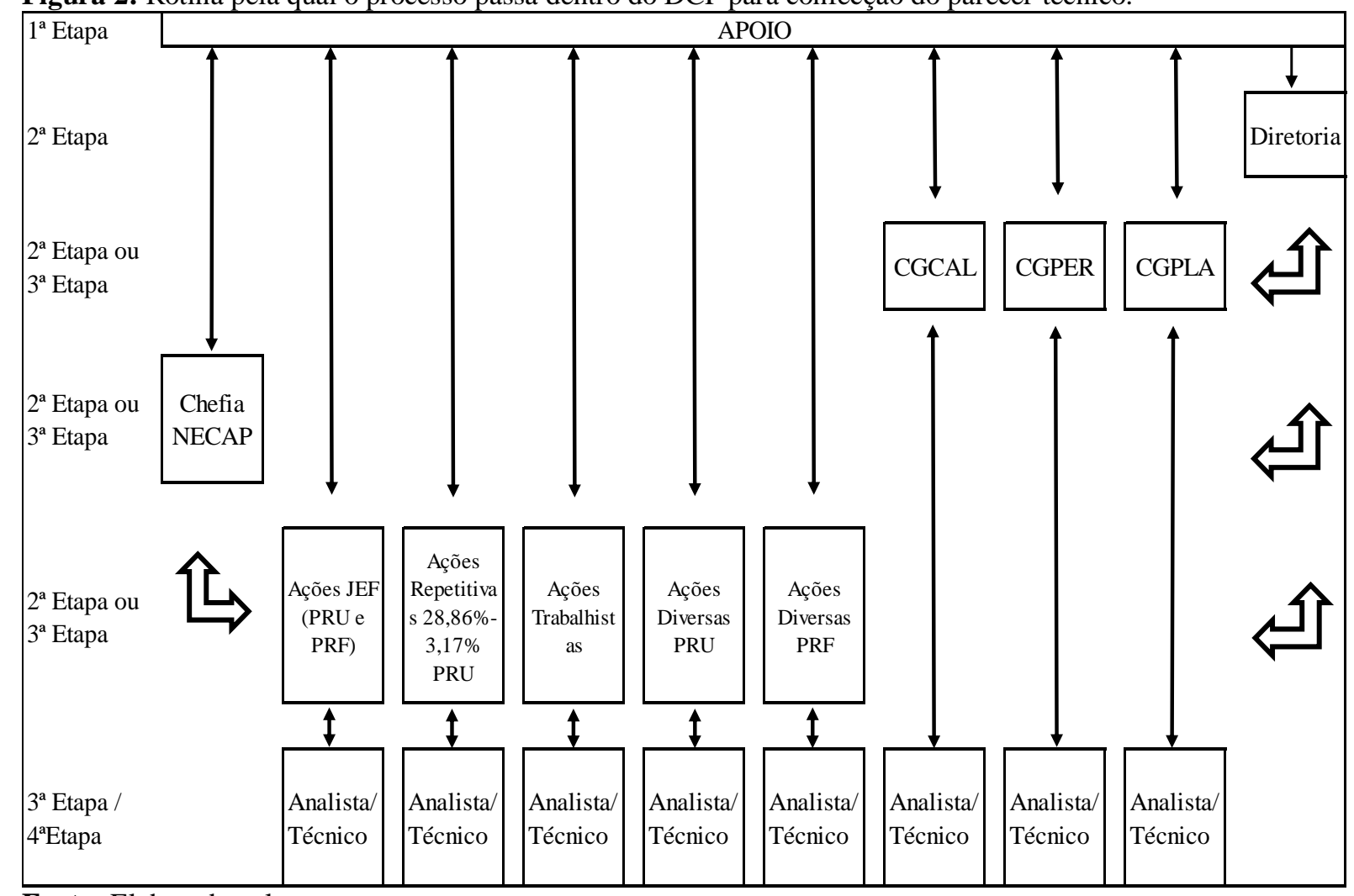

Fonte: Elaborado pelo autor. 
Desta forma as diversas etapas aqui apresentadas concorrem para a produção de uma série de diferentes pareceres técnicos que é o produto final a ter o custo mensurado neste trabalho. Destaca-se que o tempo de espera que o processo sofre durantes as etapas no DCP não foi objeto de análise individual, sendo portanto uma das limitações deste trabalho.

É importante ressaltar que dependendo do tipo e complexidade do processo e cálculo envolvido, o parecer técnico torna-se algo individual e portanto, seria melhor mensurado por um sistema de custeio por ordem de produção (GARRISON et al 2013, p.84). Em alguns casos mais esporádicos, como processos de Sindicatos ou uma grande quantidade de processos semelhantes, a elaboração dos pareceres técnicos, por um determinado analista/técnico de tão repetitiva possui características de uma linha de produção, o que seria melhor apresentado por um sistema de custeio por processo ou contínuo, entretanto, esse cenário não é a regra.

Assim, para este trabalho será considerado o sistema de custeio por ordem de produção, de forma que as etapas pela qual o processo passa (recebimento, distribuição, elaboração, correção, numeração e entrega) será sintetizada em apenas uma "elaboração do parecer", ou seja, cada pedido de análise técnica é uma ordem de produção. O custo individual de cada parecer será determinado pela média mensal, conforme demonstrado em detalhes no item 4.4.

\subsection{Amostra do Número do Pareceres}

A amostra deste trabalho é composta por dados do período de janeiro de 2011 a julho de 2014. Neste Período a base de dados Atuação, do Departamento de Cálculos e Perícias da AGU, foi alimentada com 49.975 registros.

O banco de dados Atuação, foi criado em 2005 com intuito de mensurar a atuação dos analistas/técnicos do DCP na redução dos valores executados contra a União e consequentemente a economia de recursos públicos.

A escolha do período se deu de forma a aproveitar a data inicial da informação disponível na Base de Dados Atuação até a data mais recente, de forma a não comprometer o andamento da dissertação. Apesar da base de dados Atuação existir desde 2005, devido a mudanças no servidor que armazena os dados, as informações anteriores a 2011 não estavam disponíveis.

A cada parecer técnico elaborado pelo DCP, um registro no Atuação deve ser criado. Cada registro deve conter 16 variáveis e um campo observação para preenchimento opcional. 
As 16 variáveis são as descritas na Tabela 1. As variáveis com o asterisco, foram coletadas para utilização neste trabalho.

Tabela 1: Variáveis disponíveis na Base de Dados Atuação.

\begin{tabular}{lll}
\hline 1 & Situação da União (Autora ou Ré)* & 10 Número do Parecer \\
\hline 2 & Número processo* $^{*}$ & 11 Valor Autor* \\
\hline 3 & Nome do Exequente* & 12 Valor União* \\
\hline 4 & Origem do Pedido de Análise & 13 Data envio ao DCP* \\
\hline 5 & Quantidade exequentes (autores)* & 14 Data prazo do Advogado* \\
\hline 6 & Tipo de cálculo* & 15 Data saída do DCP* \\
\hline 7 & Objeto da ação* & 16 Nome do Analista \\
\hline 8 & Órgão Representado* & Observações \\
\hline 9 & Tipo de Parecer* & \\
\hline
\end{tabular}

* Variáveis utilizadas neste trabalho.

Fonte: Elaborado pelo autor com dados do Atuação (2014)

Porém, por ser um banco de dados alimentado por várias pessoas, o Atuação possui um percentual de erro em seus registros. Tais erros podem ser agrupados em 4 classes, que são: a) Erros de digitação nos campos: 2, 3, 5, 11, 12, 13, 14, 15; b) Erros de classificação nos campos: 1, 4, 6, 7, 8, 9; c) Erros de Cadastramento em Duplicidade; d) Falta de preenchimento dos campos: 1, 3, 13, 14. Deve ser levando em conta que existe uma pequena parcela de pareceres que acabam saindo do DCP sem o devido registro do Atuação, seja por, descuido do técnico/analista, seja pela indisponibilidade do Atuação e esquecimento do lançamento posteriormente.

Os erros citados nos itens "a)" e "b)" possuem em sua maioria, um grande grau de dificuldade de correção, pois, exigem dados externos ao Atuação. Desta forma a identificação e correção desses dois tipos de erros não foi uma preocupação primordial neste trabalho e, portanto, é uma das limitações deste trabalho.

O primeiro erro a ser corrigido foi o erro do item "c)", por ser um erro independente de informações externas. Ele pôde ser verificado aplicando-se uma série de filtros com condições específicas com auxílio do programa Excel. Desta forma identificamos que dentre os 49.975 registros, 524 foram cadastrados em duplicidade, o que representa 1,049\% da população.

Ressalta-se que a quantidade de pareceres é contabilizada no momento de sua saída do DCP, independente da data de entrada e tempo efetivo de elaboração do parecer, ou seja, no cálculo mensal do custo do parecer há uma limitação no tocante a não consideração do equivalente de produção. 
Quanto ao erro do item "d)", eles somaram 4.473 registros. Tais registros não foram retirados do número total de pareceres para aferição do custo do parecer, porém, foram retirados, do cálculo da contagem do tempo de elaboração do parecer, visto que todos eles não continham as variáveis 13 e 14 destacadas no Tabela 1 .

Assim, para o cálculo do custo mensal do parecer técnico pelo método de custeio direto utilizou-se o total de 49.451 registros, conforme detalhado no Quadro 1.

Quadro 1: Quantidade mensal de pareceres técnicos emitidos de janeiro de 2011 a julho de 2014.

\begin{tabular}{|r|c|r|r|r|r|r|c|}
\hline \multicolumn{1}{|c|}{ Data } & $\begin{array}{c}\text { Total de } \\
\text { Pareceres } \\
\text { Emitidos }\end{array}$ & Data & $\begin{array}{c}\text { Total de } \\
\text { Pareceres } \\
\text { Emitidos }\end{array}$ & Data & $\begin{array}{c}\text { Total de } \\
\text { Pareceres } \\
\text { Emitidos }\end{array}$ & Data & $\begin{array}{c}\text { Total de } \\
\text { Pareceres } \\
\text { Emitidos }\end{array}$ \\
\hline jan/11 & 924 & $\mathrm{dez} / 11$ & 964 & $\mathrm{nov} / 12$ & 1102 & $\mathrm{out} / 13$ & 1155 \\
\hline $\mathrm{fev} / 11$ & 1072 & $\mathrm{jan} / 12$ & 645 & $\mathrm{dez} / 12$ & 942 & $\mathrm{nov} / 13$ & 1414 \\
\hline $\mathrm{mar} / 11$ & 1570 & $\mathrm{fev} / 12$ & 701 & $\mathrm{jan} / 13$ & 746 & $\mathrm{dez} / 13$ & 863 \\
\hline $\mathrm{abr} / 11$ & 1147 & $\mathrm{mar} / 12$ & 1319 & $\mathrm{fev} / 13$ & 904 & $\mathrm{jan} / 14$ & 709 \\
\hline $\mathrm{mai} / 11$ & 1589 & $\mathrm{abr} / 12$ & 1192 & $\mathrm{mar} / 13$ & 1106 & $\mathrm{fev} / 14$ & 1156 \\
\hline $\mathrm{jun} / 11$ & 1808 & $\mathrm{mai} / 12$ & 1597 & $\mathrm{abr} / 13$ & 1344 & $\mathrm{mar} / 14$ & 1108 \\
\hline $\mathrm{jul} / 11$ & 1434 & $\mathrm{jun} / 12$ & 1371 & $\mathrm{mai} / 13$ & 1138 & $\mathrm{abr} / 14$ & 867 \\
\hline $\mathrm{ago} / 11$ & 1576 & $\mathrm{jul} / 12$ & 1426 & $\mathrm{jun} / 13$ & 904 & $\mathrm{mai} / 14$ & 995 \\
\hline $\mathrm{set} / 11$ & 1457 & $\mathrm{ago} / 12$ & 1369 & $\mathrm{jul} / 13$ & 1029 & $\mathrm{jun} / 14$ & 917 \\
\hline out/11 & 1308 & $\mathrm{set} / 12$ & 957 & $\mathrm{ago} / 13$ & 1163 & $\mathrm{jul} / 14$ & 974 \\
\hline nov/11 & 953 & $\mathrm{out} / 12$ & 1287 & $\mathrm{set} / 13$ & 1249 & $\mathrm{TOTAL}$ & 49451 \\
\hline
\end{tabular}

Fonte: Elaborado pelo autor com dados do Atuação (2014).

O Apêndice A, detalha o número de pareceres pelo Tipo de Parecer. Essa divisão foi estabelecida na criação do Atuação, com intuito de melhor caracterizar os trabalhos desempenhados pelos analistas/técnicos, visto que, nem todo parecer tem necessariamente uma análise de cálculo, como é o caso dos pareceres de Despacho, Devolutivos e a maioria dos informativos. Neste trabalho, não será feita distinção quanto ao tipo de parecer, bem como, não será diferenciado o tempo que cada tipo de parecer leva para ser elaborado.

\subsection{Amostra dos Custos com Mão-de-Obra Direta e Materiais Diretos}

Com relação a remuneração dos servidores e requisitados que neste trabalho compõem o custo da mão-de-obra direta, visto que todos participam diretamente da produção do objeto de custo em estudo, ela será obtida através do Sistema Integrado de Administração de Recursos Humanos - SIAPE e a partir de informações dos próprios servidores no caso de requisitados de empresas públicas. Essas informações não são caracterizadas como sigilosas, de acordo com a Lei n ${ }^{\circ} 12.527$ de 18/11/2011 - Lei de acesso à informação, e também, da forma agregada como foi tratada neste trabalho, não há exposições individuais. Cabe ressaltar, que os dados das 
remunerações individuais dos servidores do DCP, estão sempre disponíveis ao acesso público através do Portal da Transparência do Governo Federal ${ }^{1}$.

Assim, para o cálculo dos custos diretos da Mão-de-obra direta $\left(M O D_{t}\right)$ foram considerados os seguintes critérios:

a) Remuneração bruta mensal dos servidores, incluindo vantagens pessoais, férias, $13^{\circ}$ salário, auxílio alimentação, auxílio transporte, restituição do plano de saúde e Previdência dos servidores lotados no DCP. Também inclui a remuneração dos servidores afastados por licença médica;

b) No caso dos requisitados com ônus para a AGU foram utilizados valores médios a partir das informações de alguns dos requisitados sobre os salários recebidos. Esse salário médio engloba o custo total da instituição cedente o que significa pagamento de férias, $13^{\circ}$ salários, FGTS, auxílio alimentação, auxílio transporte e plano de saúde;

c) No caso dos requisitados sem ônus para a AGU, que é o caso de servidores de outros órgãos da administração pública como IBAMA, CGU e IBGE, foram incluídos os salários e também a gratificação temporária paga pela AGU como estimulo a requisição. A justificativa para inclusão dos salários de tais servidores, paira no fato de além deles estarem diretamente vinculados a elaboração do parecer técnico, eles ocupam a vaga destinada a servidores do quadro da AGU, ou seja, na ausência deles a AGU faria novas contratações ou realocaria pessoal para o DCP;

d) Todos os valores referentes a pagamento de função comissionada;

e) Não foram incluídas as remunerações dos servidores que se aposentaram pelo DCP e também dos pensionistas de servidores que faleceram enquanto trabalhavam no DCP, conforme Morgan (2004) e Magalhães et al (2010);

f) Não foram incluídas diárias recebidas por viagens a trabalho nem gastos com transportes para audiências ou reuniões fora da AGU;

g) Não foram incluídas as remunerações de copeiras, garçons, guardete e funcionários da limpeza, visto que o serviço prestado por eles atende mais

\footnotetext{
${ }^{1}$ http://www.portaltransparencia.gov.br/
} 
setores que apenas o Departamento de Cálculos e Perícias, de forma que caracteriza-se como um custo indireto.

A fim de reduzir o impacto sazonal existente com o $13^{\circ}$ salário e o $1 / 3$ de férias foi realizado um rateio mensal desses valores, ou seja, o salário mensal (sem $13^{\circ}$ e $1 / 3$ de férias) de cada servidor do DCP foi multiplicado por 1,083333333 refere ao $13^{\circ}$ e por 1,027777778 referente ao $1 / 3$ de férias.

O Quadro 2, discrimina os valores utilizados no cálculo do custo do parecer técnico, a título de mão-de-obra direta.

Quadro 2: Valor da mão-de-obra direta no período de janeiro de 2011 a julho de 2014.

\begin{tabular}{|c|c|c|c|c|c|c|c|}
\hline Data & Remuneração & Data & Remuneração & Data & Remuneração & Data & Remuneração \\
\hline $\mathrm{jan} / 11$ & $482.162,81$ & $\mathrm{dez} / 11$ & $528.512,10$ & nov/12 & $542.873,69$ & out/13 & $529.133,62$ \\
\hline fev/11 & $505.157,89$ & jan/12 & $531.083,40$ & dez/12 & $549.281,24$ & nov/13 & $525.437,63$ \\
\hline $\mathrm{mar} / 11$ & $505.881,74$ & $\mathrm{fev} / 12$ & $533.502,48$ & $\mathrm{jan} / 13$ & $534.712,81$ & $\mathrm{dez} / 13$ & $549.077,22$ \\
\hline $\mathrm{abr} / 11$ & $507.324,84$ & $\mathrm{mar} / 12$ & $506.606,12$ & fev/13 & $505.354,70$ & $\mathrm{jan} / 14$ & $544.206,44$ \\
\hline mai/11 & $497.782,67$ & $\mathrm{abr} / 12$ & $500.925,94$ & $\mathrm{mar} / 13$ & $518.693,58$ & fev/14 & $526.951,64$ \\
\hline jun/11 & $491.264,77$ & mai/12 & $503.788,83$ & $\mathrm{abr} / 13$ & $511.312,87$ & mar/14 & $523.209,60$ \\
\hline $\mathrm{jul} / 11$ & $504.797,47$ & jun/12 & $505.910,29$ & mai/13 & $510.303,52$ & abr/14 & $524.864,60$ \\
\hline $\mathrm{ago} / 11$ & $498.069,33$ & $\mathrm{jul} / 12$ & $533.619,85$ & jun/13 & $515.624,73$ & mai/14 & $516.894,78$ \\
\hline set/11 & $499.927,22$ & ago/12 & $536.435,72$ & $\mathrm{jul} / 13$ & $528.835,83$ & jun/14 & $510.758,03$ \\
\hline out/11 & $510.293,83$ & set/12 & $521.426,25$ & $\mathrm{ago} / 13$ & $524.610,00$ & $\mathrm{jul} / 14$ & $494.953,65$ \\
\hline nov/11 & $522.983,15$ & out/12 & $532.318,34$ & set/13 & $518.232,22$ & & \\
\hline
\end{tabular}

Fonte: Elaborado pelo autor com dados do SIAPE em valores correntes.

As informações sobre os materiais diretos, foram obtidas no próprio DCP que quando solicita material ao setor de compras da AGU recebe a guia com a quantidade enviada e o preço que cada item foi adquirido. Ressalta-se que no mês de janeiro de 2011 não houve entrega de material, e a partir de julho de 2013 a AGU iniciou a terceirização das impressões (outsourcing), e portanto, a demanda por cartucho fichou restrita a impressoras que atendem as coordenações e os custos relacionados as impressoras terceirizadas não foram considerados em virtude da falta de dados de forma individual.

Desta forma os materiais diretos (Mat.Diretos $\left.{ }_{t}\right)$ foram compostos por:

a) Materiais de escritório (expediente) necessários para elaboração do parecer, tais como Resmas de Papel A4, canetas, CD's, envelopes, entre outros.

b) Cartuchos de impressora; 
c) Não foram computados os custos de materiais permanentes, como equipamentos de informática e mobiliário. Desta forma tal custo configura como uma das limitações deste trabalho.

Assim, o montante mensal dos valores utilizados no cálculo do custo do parecer técnico, a título de materiais diretos estão no Quadro 2. O Apêndice B detalha tais valores.

Quadro 3: Valor Mensal dos materiais diretos no período de janeiro de 2011 a julho de 2014.

\begin{tabular}{|r|r|r|r|r|r|r|r|}
\hline \multicolumn{1}{|c|}{ Data } & $\begin{array}{c}\text { Materiais } \\
\text { Diretos }\end{array}$ & Data & $\begin{array}{c}\text { Materiais } \\
\text { Diretos }\end{array}$ & Data & $\begin{array}{c}\text { Materiais } \\
\text { Diretos }\end{array}$ & Data & $\begin{array}{c}\text { Materiais } \\
\text { Diretos }\end{array}$ \\
\hline jan/2011 & - & dez/2011 & $3.830,55$ & nov/2012 & $2.707,45$ & out/2013 & 798,36 \\
\hline fev/2011 & $7.784,75$ & jan/2012 & $1.734,91$ & dez/2012 & $1.181,86$ & nov/2013 & 987,59 \\
\hline mar/2011 & $7.342,11$ & $\mathrm{fev} / 2012$ & $4.134,82$ & jan/2013 & $1.069,67$ & $\mathrm{dez} / 2013$ & 889,63 \\
\hline abr/2011 & $4.563,48$ & $\mathrm{mar} / 2012$ & $3.329,12$ & $\mathrm{fev} / 2013$ & 534,31 & $\mathrm{jan} / 2014$ & 756,30 \\
\hline $\mathrm{mai} / 2011$ & $6.510,66$ & $\mathrm{abr} / 2012$ & $4.785,21$ & $\mathrm{mar} / 2013$ & $3.813,07$ & $\mathrm{fev} / 2014$ & 237,92 \\
\hline jun/2011 & $8.234,07$ & $\mathrm{mai} / 2012$ & $4.367,63$ & $\mathrm{abr} / 2013$ & $1.862,60$ & $\mathrm{mar} / 2014$ & 710,87 \\
\hline $\mathrm{jul} / 2011$ & $7.434,85$ & $\mathrm{jun} / 2012$ & $3.557,91$ & $\mathrm{mai} / 2013$ & $2.738,00$ & $\mathrm{abr} / 2014$ & 830,07 \\
\hline $\mathrm{ago} / 2011$ & $2.325,24$ & $\mathrm{jul} / 2012$ & $1.787,03$ & $\mathrm{jun} / 2013$ & $2.733,42$ & $\mathrm{mai} / 2014$ & $1.220,35$ \\
\hline set/2011 & $2.775,75$ & $\mathrm{ago} / 2012$ & $2.096,92$ & $\mathrm{jul} / 2013$ & 887,15 & $\mathrm{jun} / 2014$ & 814,32 \\
\hline out/2011 & $1.935,47$ & $\mathrm{set} / 2012$ & $1.901,65$ & $\mathrm{ago} / 2013$ & $1.187,15$ & $\mathrm{jul} / 2014$ & 774,25 \\
\hline nov/2011 & $3.866,47$ & $\mathrm{out} / 2012$ & $2.327,45$ & $\mathrm{set} / 2013$ & $1.074,90$ & & \\
\hline
\end{tabular}

Fonte: Elaborado pelo autor com dados de controle de entrega de materiais ao DCP, todos em valores correntes.

É interessante ressaltar, que em teoria os materiais que chegam ao Apoio do DCP e ainda não foram utilizados não podem ser considerados efetivamente como custos, pois ainda não foram consumidos. Entretanto, como na prática tais materiais ou são consumidos no decorrer do mês ou nos meses seguintes ou são descartados pelo decurso do prazo de validade, para apropriação dos custos, o custo dos materiais de escritório foi computado na data de recebimento de tais materiais.

Para uma melhor comparação temporal do custo do parecer técnico, os valores dos custos diretos serão atualizados pelo IPCA-E (Índice Nacional de Preço ao Consumidor Amplo Especial) para o mês de Janeiro de 2015. A correção monetária dos valores visa reduzir os efeitos da inflação, deslocando o foco das variações nos custos para outras variáveis. Os valores do IPCA-E foram obtidos no site da Justiça Federal do Distrito Federal ${ }^{2}$.

\footnotetext{
${ }^{2}$ http://portal.trf1.jus.br/sjdf/processual/calculos-custas-e-despesas-processuais/calculos-custas-e-despesas-processuais.htm
} 


\subsection{Agrupamento das observações analisadas}

A fim de identificar as principais demandas, bem como mensurar de forma pontual a expectativa de ganho dos diversos setores jurídicos que demandam o DCP, o Atuação possui previamente cadastrado uma relação de 78 objetos de ações judiciais e/ou administrativas.

Já com o intuito de registrar a fase processual na qual se encontra o processo quando da solicitação do parecer técnico, o Atuação possui uma relação de 26 tipos de cálculo.

A grande diversidade de objetos de ação e tipos de cálculo serve para subsidiar o DCP na construção de relatórios específicos para um tipo de objeto da ação ou um grupo com características semelhantes.

Entretanto, após primeira análise dos dados, verificou-se que a análise individual dos 78 objetos de ações, bem como dos 26 tipos de cálculo poderia gerar alguns resultados semelhantes tornando este trabalho menos produtivo. Assim, escolheu-se agregar os dados, a partir das técnicas de análise de agrupamentos, de forma que os novos grupos mantivessem as características individuais de cada ação.

Segundo Hair et al (2009, p.430) a análise de agrupamentos é um grupo de técnicas multivariadas cuja finalidade principal é agregar objetos com base em características que eles possuem. A análise de agrupamentos se assemelha a análise fatorial em seu objetivo de avaliar uma estrutura. Elas diferem em dois principais aspectos: a análise de agrupamentos agrega objetos de uma determinada variável com base em distância (proximidade) e; a análise fatorial agrega principalmente variáveis a partir de padrões de variação (correlação) (HAIR et al 2009, p. 430).

É importante ressaltar que o agrupamento das variáveis tipo de cálculo, e objeto da ação, não reduziram o número de registros a serem analisados, apenas sintetizou a quantidade de denominações dessas variáveis.

\subsubsection{Agrupamento do Tipo de Cálculo e Objeto da Ação}

Para agregação das denominações constantes nas variáveis tipo de cálculo e objeto da ação foi utilizado o procedimento não-hierárquico pelo método de otimização.

Conforme detalhando em Hair et al (2009, p.452), os procedimentos não-hierárquicos de agrupamento possuem essencialmente dois passos:

I. Especificação das sementes de agrupamento: Neste momento devem ser identificadas as observações de partida (sementes) para cada agrupamento. A semente de agrupamento pode ser pré-especificada pelo pesquisador. 
II. Designação: Definidas as sementes de agrupamento, passa-se a segunda etapa que é designar cada observação a uma das sementes que lhe seja similar. Dependendo da abordagem as observações podem ser redirecionadas a agrupamentos com maior semelhança após uma atribuição inicial. Esse procedimento é denominado por Hair et al (2009, p.453) de procedimento de otimização.

Nestes termos o agrupamento das denominações referentes ao tipo de cálculo e ao objeto da ação obedeceram a seguinte ordem: 1) cada observação inicial era uma semente; 2) cada observação seguinte era comparada com observações anteriores para verificar a similaridade; 3) formado grupo com similaridade comparou-se observações entre os grupos para otimizar a similaridade entre as observações.

Desta forma dentre os 26 tipos de cálculo inicialmente contidos na base de dados Atuação, após os agrupamentos restaram 12 tipos de cálculo, conforme tabela apresentada no Apêndice D. É interessante ressaltar que nem todas as observações foram agrupadas, em razão da baixa similaridade e que após o agrupamento também houve a mudança da nomenclatura do grupo para melhor representar seus componentes. Como exemplo de agrupamento do tipo de cálculo citam-se os dois maiores agrupamentos:

i. O maior agrupamento do tipo de cálculo foi denominado "Propositura de Ação Auto Execução" e agrupou os tipos de cálculo denominados: Propositura de Ação; Propositura de Ação Rescisória; Proposta de Acordo - Portaria 1052 e 1053/06; Tomada de Conta (TCU); Auto Execução e; Parcelamento de Débito. A similaridade deste agrupamento reside no fato dos cálculos aqui apresentados serem de iniciativa da União e no caso do parcelamento, ele é uma consequência de uma iniciativa anterior da União em recuperar um débito provocado pelo réu.

ii. O segundo maior agrupamento do tipo do cálculo foi denominado de "Cálculos Periciais" e agrupou: Indicação de Assistente; Laudo Pericial; Elaboração de Quesitos e; Outros Procedimentos Perícia. A similaridade desses tipos de cálculo está atrelada ao grupo técnico responsável pela elaboração desses pareceres que é a Coordenação-Geral de Perícias.

De forma análoga ao realizado para o tipo de cálculo, os 78 objetos da ação, foram agregados em 24 grupos conforme demonstrado no Apêndice C. 
i. O maior agrupamento do objeto da ação foi denominado "Perícia". Ele agregou 14 objetos da ação que possuem como similaridade um parecer técnico com uma série de quesitos que serão respondidos pelo perito do juízo.

ii. O segundo maior agrupamento do objeto da ação ficou a cargo do grupo "Gratificações de Desempenho - Diversas". Este agrupamento reuniu as 12 gratificações de desempenho mais demandadas, acrescida do grupo que reúne todas as demais gratificações de desempenho existentes.

iii. O terceiro maior agrupamento do objeto da ação foi denominado "Diferenças Salariais (Equiparação, Reenquadramento, Reintegração)". Ele englobou 11 diferentes nomenclaturas de objeto da ação, que tratam em todos os casos de diferenças salariais, seja de Reenquadramento onde se pleiteia a mudança, por exemplo de uma carreira de técnico para analista, seja de diferenças em rubricas específicas, como por exemplo, férias, horas extras e indenização de campo FUNASA.

É importante citar que o segundo maior grupo "Gratificações de Desempenho Diversas" em teoria poderia estar dentro do grupo "Diferenças Salariais (Equiparação, Reenquadramento, Reintegração)", porém, optou-se por manter esses grupos em separados para captar a importância individual das "Gratificações de Desempenho - Diversas" que em sua grande maioria versão sobre a diferença salarial sofrida por inativos e pensionistas frente aos ativos.

\subsection{Fórmulas utilizadas na mensuração dos custos do parecer técnico}

Para o cálculo dos custos diretos atrelados a elaboração do parecer técnico pelo DCP foram consideradas as seguintes equações:

$$
\begin{aligned}
& C T_{t}=M O D_{t}+\text { Mat. Diretos } t \\
& \text { C.Med.PT } T_{t}=\frac{M O D_{t}+\text { Mat.Diretos }}{t}
\end{aligned}
$$

Onde:

$C T_{t}$ : Custo total dos pareceres técnicos realizado pelo DCP no mês (t);

$M O D_{t}$ : Remuneração da mão-de-obra direta no mês (t);

Mat.Diretos: : Material de expediente consumido no mês (t);

$Q$ de $P T_{t}$ : Quantidade total de pareceres que saíram do Apoio do DCP no mês (t); 
C. Med. $P T_{t}$ : Custo médio do parecer técnico por mês (t).

É interessante citar aqui que caso quiséssemos mensurar o custo por hora do parecer técnico, não poderíamos simplesmente utilizar a equação (2) dividindo-a pelo número de horas, pois, no atual formato ela não leva em conta o tempo que o processo fica parado no DCP aguardando análise. Desta forma, pela equação (2) o custo da hora seria representado de forma incorreta, levando-nos a concluir que quanto maior o tempo que o processo passa no DCP para ser analisado, menor o custo do parecer técnico (produto final).

Apesar do cálculo do custo da hora trabalhada está fora do objetivo deste trabalho, verificou-se na literatura (KAPLAN e ANDERSON, 2004; PERNOT et al, 2007; SILVA et al, 2011) que o Método de Custeio TDABC pode ser o mais adequado para mensuração deste valor, entretanto exigiria dados ainda não disponíveis, como por exemplo, o tempo que o processo passa parado aguardando análise e o tempo que o analista/técnico passa efetivamente analisando o processo.

Com relação ao cálculo da margem de contribuição direta de cada parecer técnico para a União, serão relacionados os valores apurados como excesso partindo-se das seguintes equações:

$$
\begin{aligned}
& \operatorname{MCDm}_{t}=\text { E.Med.t }_{\cdot}-\text { C.Med.PT } \\
& \Sigma E_{i, t}=\text { Valor Autor } \\
& i, t
\end{aligned}
$$

Onde:

$M C D m_{t}$ : Margem de Contribuição Direta média do Parecer no mês (t);

E. Med.t: Excesso Médio apurado no mês (t);

C. Med. $P T_{t}$ : Custo médio do parecer técnico por mês (t);

$\Sigma E_{t}$ : Somatório do excesso apurado na observação (i) no mês (t). Também representa o somatório das observações referentes ao Objeto da Ação e o Tipo de Parecer;

Valor Autor ${ }_{t}$ V Valor que o Autor Executa na Ação (Variável 11 - Tabela 1);

Valor União $o_{t}$ : Valor que a União entende como devido na Ação (Variável 12 - Tabela 1). 


\subsection{Metodologia para apuração da concordância}

A partir da igualdade entre as variáveis (11) e (12), apresentadas na Tabela 1, foi verificado o percentual médio de concordância. A concordância foi apurada a partir da criação de uma variável dummy. Sobre a variável dummy atribui-se o valor 1 (um) para o caso em o valor da União é igual ou maior ao valor do autor exequente/autor, e 0 (zero) para o caso em que há excesso entre o valor apurado pelo autor e o valor apurado pela União.

É importante frisar que o percentual de concordância só foi apurado para os casos em que a União é Ré/Executada. 


\section{ANÁLISE DOS DADOS E RESULTADOS}

\subsection{Valor do Parecer Pelo Método Direto}

Inicialmente tratou-se de apurar o custo mensal médio do parecer técnico. Os dados apresentados nos Quadros 1, 2 e 3 foram tratados a partir das equações (2) e (3) cujo resultado é apresentado na tabela disposta no Apêndice E, que está em moeda corrente.

O Gráfico 1 mostra a evolução no período da pesquisa do custo médio mensal pelo método direto com os valores atualizados até janeiro de 2015 para melhor comparação entre os meses. Nele verifica-se inicialmente uma leve tendência de aumento do custo médio mensal no período.

Gráfico 1: Evolução do Custo Médio Mensal do Parecer pelo Método Direto em Valores de Janeiro de 2015.

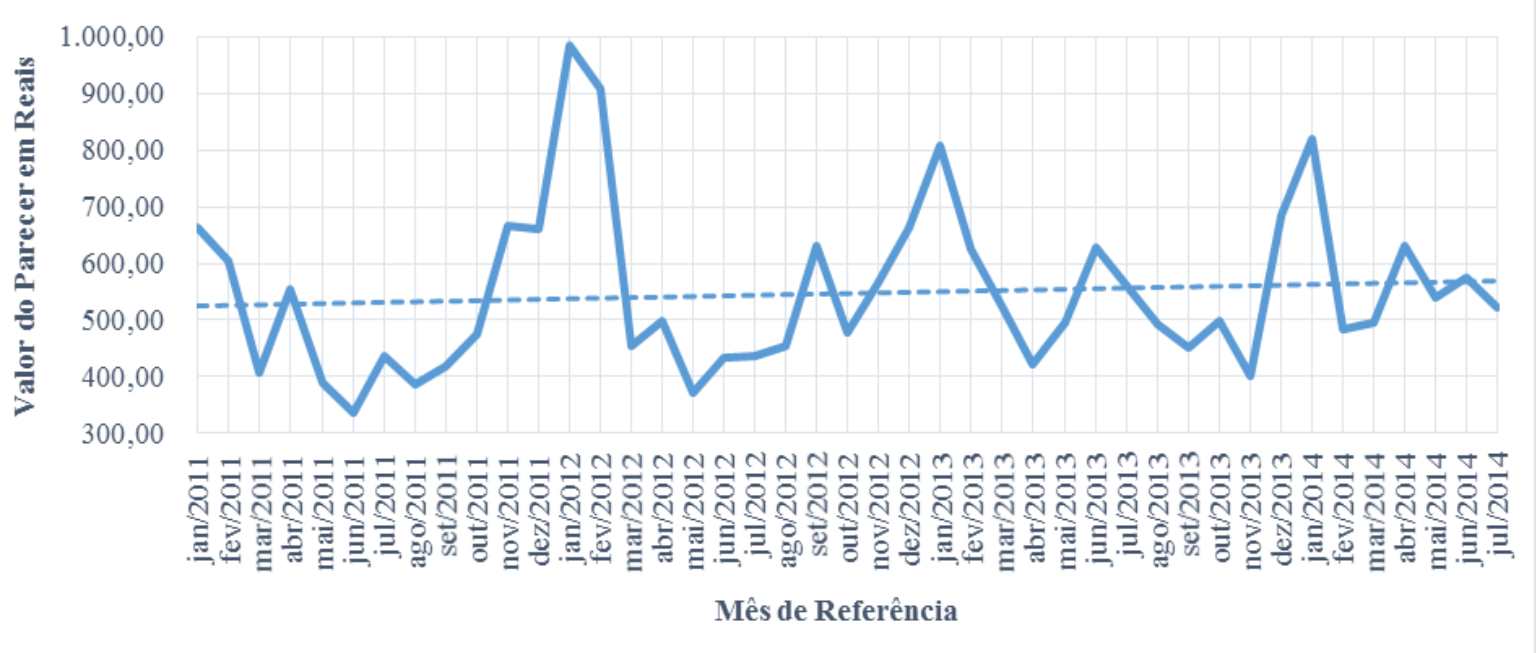

Fonte: Elaborado pelo autor.

No Gráfico 1, a primeira vista, pode-se pensar que há uma influência do $13^{\circ}$ salário ou $1 / 3$ de férias, porém, tais valores ( $13^{\circ}$ e $1 / 3$ de férias) foram rateados de forma mensal, levandose em conta o princípio da competência, conforme já detalhado no item 4.3.

O que explica um maior custo verificado nos meses de janeiro é a menor demanda por pareceres judiciais, em parte devido aos recessos de natal e ano novo, onde as remessas de processos do Judiciário à AGU são reduzidas e consequentemente a demanda por pareceres do DCP também é reduzida. É possível verificar no Quadro 1 o menor número de pareceres emitidos nos meses de janeiro.

Por outro lado, os menores custos decorrem do aumento natural da demanda por pareceres no DCP nos meses de abril, maio e junho em virtude do prazo final de inscrição dos precatórios ( $1^{\circ}$ de julho) na proposta orçamentária do ano seguinte, para que possam ser pagos. 
O Custo médio mensal do parecer técnico para o período do estudo ficou em $\mathrm{R} \$ 547,25$ em valores de janeiro de 2015. Entretanto, conforme pode ser verificado no Gráfico 2, que apresenta o Histograma do custo médio mensal do parecer, o gráfico é assimétrico à direita ou positivo (Assimetria 1,191), proporcionando uma mediana aproximadamente $9 \%$ menor que a média. O valor da mediana foi de $\mathrm{R} \$ 498,53$. O desvio padrão encontrado ficou em $\mathrm{R} \$ 142,88$ o que representa aproximadamente $26 \%$ da média. Além de assimétrico, o valor da curtose encontrado pelo SPSS foi 1,468, demonstrado que a curva é Platicúrtica, ou seja, ela é mais achatada que a curva normal confirmando a maior dispersão dos dados.

Gráfico 2: Histograma do Custo Médio Mensal do Parecer pelo Método Direto em Valores de Janeiro de 2015.

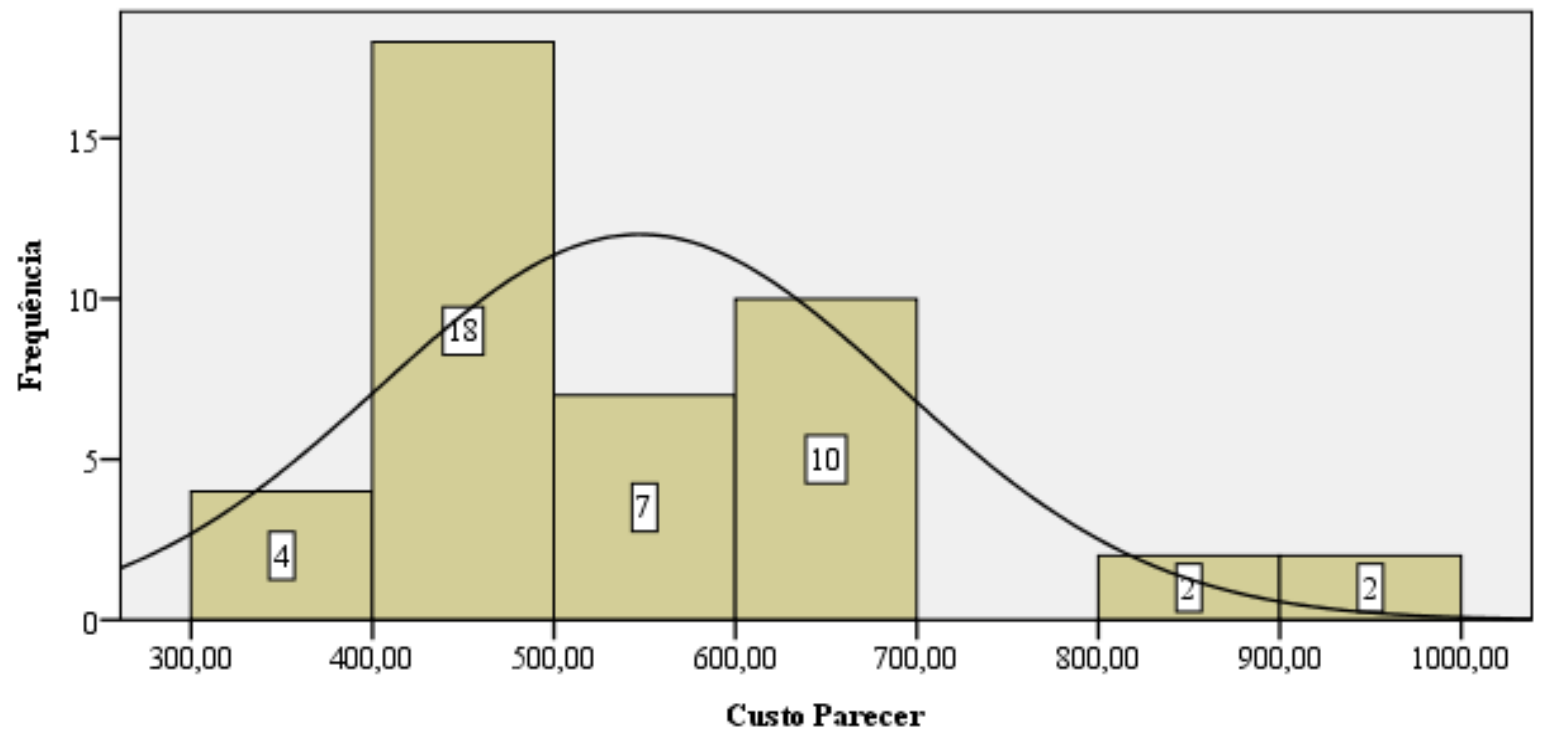

Fonte: Elaborado pelo autor.

A literatura relata que nos casos em que a média for distante da mediana, devido, por exemplo, a existência de valores extremos, ou quando a distribuição de frequência seja assimétrica, a mediana passa a ser a medida de tendência central mais fiel a realidade dos dados (STEVENSON, 1981, p.23; TRIOLA, 1999, p. 35).

A realização dos testes de normalidade de Kolmogorov-Smirnov e de Shapiro-Wilk, através do SPSS, com 95\% de nível de significância, resultaram nos valores de $p$-value de 0,024 e 0,002 respectivamente. De acordo com Salvatore e Reagle (2011, p. 94) o teste não paramétrico de Kolmogorov-Smirnov compara a probabilidade acumulada dos dados para uma distribuição hipotética e identifica a maior diferença entre as probabilidades acumuladas para comparar com uma tabela própria.

Lopes et al (2013) detalham a forma como o resultado emitido pelo SPSS deve ser interpretado. Assim, valor do p-value fornecido pelo SPSS através da sigla "Sig." deve ser interpretado "como a medida do grau de concordância entre os dados e a hipótese nula $\left(\mathrm{H}_{0}\right)$ " 
segundo Lopes et al (2013). A hipótese nula $\left(\mathrm{H}_{0}\right)$ é definida como se a distribuição normal fosse a verdadeira. Consequentemente, a regra de decisão é: se $p$-value $\leq \alpha$ (nível de significância) então rejeita-se $\mathrm{H}_{0}$; se $p$-value $\geq \alpha$ então não rejeita-se $\mathrm{H}_{0}$ comprovando a hipótese da distribuição corresponder a normal (LOPES et al, 2013).

Como os resultados apresentados pelo SPSS foram 0,024 e 0,002, ambos são menores que $0,05(\alpha=5 \%)$, demonstrando assim a rejeição de $\mathrm{H}_{0}$ e consequentemente aceitação de $\mathrm{H}_{1}$ hipótese que afirma que os dados não descrevem uma distribuição normal.

Portanto, o valor que melhor representa o custo médio mensal calculado do parecer técnico emitido pelo DCP, calculado pelo método direto, no período do estudo é o montante de $\mathrm{R} \$ 498,53$ em janeiro de 2015, que corresponde a mediana.

Esse valor do custo mediano representa um importante norte para um primeiro passo no aumento na eficiência do trabalho desempenhado pelo DCP, já que a partir dele pode-se sugerir que demandas abaixo desse valor não sejam analisadas, em momentos de grande fluxo de trabalho e simplesmente o DCP concorde com o pleito da parte autora. A título de informação, essa demanda (processos com valores executados abaixo de $\mathrm{R} \$ 498,53$ ) representou uma média de 14 pareceres no mês, ou seja, aproximadamente $1,2 \%$ da demanda média mensal, impactando de forma desprezível e imaterial nos valores de excesso apurados pelo DCP, além do que o percentual de concordância, dos pareceres do DCP com a conta do autor, neste grupo ficou em $90 \%$.

\subsection{Perda de Informação de Custos pela Utilização do Método Direto}

A título de demonstração da perda de informação decorrente da utilização do método de custeio direto, apresentou-se no Apêndice E, os valores referentes ao aluguel do espaço físico do DCP para todo período da pesquisa, e também, outros custos indiretos (discriminados no Apêndice F) referentes apenas ao primeiro semestre de 2014 devido a disponibilidade de dados.

Constatou-se que para o período de janeiro de 2011 a dezembro de 2013, onde só há disponibilidade de informações referentes ao aluguel, o custo do parecer seria em média pelo menos $11,36 \%$ maior utilizando-se outro método que incluísse os custos indiretos. Para a demonstração foi utilizado o método absorção. A mediana ficou em 11,23\% maior e o desvio padrão amostral em $0,60 \%$.

É importante esclarecer que neste caso o rateio do custo do imóvel foi realizado com base na área $\left(\mathrm{m}^{2}\right)$ utilizada pelo DCP. Este é o mesmo critério utilizado pelas coordenações de contabilidade e orçamento da AGU para o cálculo do custo incorrido nas unidades orçamentárias lotadas no prédio Sede I da AGU. Ressalta-se que o DCP não é uma unidade 
orçamentária independente, ele faz parte da Unidade PGU, ou seja, dentro da área ocupada pela PGU $\left(2062 \mathrm{~m}^{2}\right)$ foi retirada a área aproximada referente ao DCP $\left(475,84 \mathrm{~m}^{2}\right)$. Além disso, na metragem disponibilizada pelas coordenações de contabilidade e orçamento, já está inclusa o rateio das áreas comuns, como por exemplo os 4 subsolos de garagem, sendo este rateio das áreas comuns foi realizado pelo número de servidores em cada unidade e não mais pela área das unidades orçamentárias.

Os custos incorridos no edifício Sede I da AGU, são sempre rateados ou pela área ocupada por cada unidade, ou pelo número de servidores lotados em cada uma das 9 unidades orçamentárias que ocupam o edifício. As informações centrais estão dispostas na Tabela 2.

Tabela 2: Área e número de servidores por unidade lotada no Edifício Sede I da AGU utilizados para de rateio dos custos indiretos.

\begin{tabular}{|c|c|c|c|c|c|c|c|c|c|}
\hline \multirow[b]{2}{*}{ Quantidade } & \multicolumn{9}{|c|}{ Unidades } \\
\hline & $\begin{array}{l}\text { GAB- } \\
\text { AGU }\end{array}$ & $\mathrm{CGU}$ & DGE & SGCS & SGCT & PGF & PGU & PRF $1^{a}$ & $\operatorname{PRU} 1^{\mathrm{a}}$ \\
\hline $\mathbf{M}^{2}$ por Unidade & 471 & 1295 & 379 & 163 & 1061 & 2110 & 2062 & 2162 & 2175 \\
\hline$N^{o}$ de Servidores & 164 & 138 & 25 & 108 & 131 & 228 & 271 & 171 & 234 \\
\hline
\end{tabular}

Fonte: Elaborado pelo autor a partir de informações do SIC disponibilizadas pela Coordenação de Contabilidade e Orçamento da AGU, posição 01/10/2014.

Já para o período de janeiro de 2014 a julho de 2014, há disponibilidade de praticamente todos os custos atrelados ao edifício Sede I (vide Apêndice F). Desta forma se acrescentarmos os custos indiretos dispostos no Apêndice F, rateados pela área do DCP, os resultados serão os valores apurados na quarta coluna do Apêndice E, que adicionados ao aluguel, geraria um aumento médio de $20,71 \%$ no custo do parecer técnico para o período citado.

Assim, verifica-se que após a inclusão de todos os custos incorridos no período de janeiro de 2014 a julho de 2014, a apuração dos custos pelo método de custeio direto proporcionou um valor em média $20,71 \%$ menor que o que seria apurado se os custos indiretos fossem considerados. A mediana ficou em 20,75\% e o desvio padrão amostral em 1,90\%.

Ressalta-se aqui, que uma das limitações desse trabalho, paira na não inclusão dos custos referentes aos setores que dão suporte a todos os demais setores da AGU, como exemplo, o RH, a contabilidade e o orçamento. A inclusão de tais setores nos custos indiretos, como certeza proporcionaria um aumento na diferença entre o método absorção e o método de custeio direto.

Não foram encontrados trabalhos que mostrassem o percentual de "perda de informação" referente aos custos indiretos, ao se utilizar o método direto. Portanto, a comparação neste ponto ficou prejudicada.

É interessante ressaltar aqui, que o Governo Federal vem avançando na exigência de que os entes administrativos tenham controle detalhado dos gastos realizados e alimentem os 
respectivos sistemas de controle. O Sistema de Informações de Custos do Governo Federal, que une vários sistemas de controle já está em operação e em alguns anos, pesquisas como essa disporão de uma longa série histórica para dar melhor subsídio sobre, por exemplo, qual o melhor critério de rateio a ser utilizado nos gastos indiretos.

\subsection{Análise do Objeto da Ação e do Tipo de Cálculo}

A grande variedade de Objetos da Ação (78) e Tipos de Cálculo (26) relacionados no Atuação, proporciona uma infinidade de combinações de informações que podem ser geradas a depender do objetivo a ser atendido.

Neste trabalho a preocupação com a apuração do custo dispendido na elaboração do parecer técnico pelo DCP, tem como finalidade a verificação da margem de contribuição direta média MCDm deste Departamento para União. A MCDm neste caso é calculada a partir das equações (4) e (5) apresentadas no tópico 4.5.

\subsubsection{Análise por Objeto da Ação}

Ao analisarmos os pareceres emitidos pelo DPC a partir dos Objetos da Ação (tema principal tratado na ação judicial) agrupados conforme demonstrado no item 4.4.1. e no Apêndice C, verificou-se, conforme Tabela 3, que as dez principais demandas são as dos grupos: Gratificações de Desempenho - Diversas com 43,78\%; Reajuste Salarial 28,86\% (Civil e Militar) com 14,82\%; Diferenças Salariais (Equiparação, Reenquadramento e Reintegração) com 14,58\%; Resíduo dos 3,17\% (Lei 8.880/94) com 8,56\%; Honorários Advocatícios (União - Autora) com 3,93\%; Indenizações com 2,70\%; Perícia com 2,07\%; Quintos/décimos/VPNI com 1,58\%; União - Subsidiária com 1,22\% e; Reajuste Conversão URV - 10,94\% / 11,98\% com $1,21 \%$. Juntos esses 10 grupos responderam por $94,43 \%$ da demanda por pareceres técnicos ao DCP.

A Tabela 3 também traz informações referentes ao percentual de concordância dos pareceres do DCP com os valores pleiteados pelos autores e informações sobre o tempo de elaboração do parecer técnico. 
Tabela 3: Quantidade Pareceres Emitidos por Objeto da Ação, Percentual de Representatividade, Percentual Médio de Concordância e Mediana do Tempo de Elaboração.

\begin{tabular}{|c|c|c|c|c|}
\hline Objetos da Ação & $\begin{array}{c}\text { Contagem } \\
\text { do Objeto } \\
\text { da ação }\end{array}$ & $\begin{array}{c}\text { Percentual de } \\
\text { Representativid } \\
\text { ade }\end{array}$ & $\begin{array}{c}\text { Percentual } \\
\text { Médio de } \\
\text { Concordância } \\
(1) \\
\end{array}$ & $\begin{array}{c}\text { Mediana do } \\
\text { Tempo de } \\
\text { Elaboração (Dias) } \\
\text { (2) } \\
\end{array}$ \\
\hline Acórdão TCU e Administrativos & 252 & $0,51 \%$ & $0,00 \%$ & 7 \\
\hline Adicional por Tempo de Serviço (Anuênio... & 200 & $0,40 \%$ & $38,71 \%$ & 6 \\
\hline Auxílio Alimentação & 334 & $0,68 \%$ & $59,36 \%$ & 15 \\
\hline Contribuição Social (Inativo) & 133 & $0,27 \%$ & $63,16 \%$ & 7 \\
\hline Danos Morais e Materiais & 356 & $0,72 \%$ & $59,25 \%$ & 7 \\
\hline Desapropriação Direta e Indireta e Reint... & 111 & $0,22 \%$ & $63,79 \%$ & 6 \\
\hline Diferenças Salariais (Equiparação.... & 7208 & $14,58 \%$ & $51,80 \%$ & 8 \\
\hline Diferenças Verbas SUS & 100 & $0,20 \%$ & $40,00 \%$ & 4 \\
\hline FUNDEF & 86 & $0,17 \%$ & $38,24 \%$ & 13 \\
\hline Gratificações de Desempenho - Diversas & 21649 & $43,78 \%$ & $79,76 \%$ & 14 \\
\hline Honorários Advocatícios (União - Autora) & 1942 & $3,93 \%$ & $0,00 \%$ & 7 \\
\hline Indenizações & 1336 & $2,70 \%$ & $55,23 \%$ & 6 \\
\hline Outros - A especificar & 83 & $0,17 \%$ & $89,39 \%$ & 16 \\
\hline Parcelamento & 241 & $0,49 \%$ & $93,65 \%$ & 8 \\
\hline Perícia & 1025 & $2,07 \%$ & $23,40 \%$ & 3 \\
\hline Planos Bresser, Collor e Verão & 115 & $0,23 \%$ & $50,00 \%$ & 7 \\
\hline Quintos/décimos/VPNI & 779 & $1,58 \%$ & $43,11 \%$ & 8 \\
\hline Reajuste - URP Abril/Maio/88 - 16,19\% & 223 & $0,45 \%$ & $8,74 \%$ & 5 \\
\hline Reajuste Conversão URV - 10,94\% / 11,98\% & 596 & $1,21 \%$ & $38,27 \%$ & 6 \\
\hline Reajuste Salarial 28,86\% (Civil e Militar) & 7328 & $14,82 \%$ & $49,18 \%$ & 7 \\
\hline Resíduo dos 3,17\% (lei 8.880/94) & 4232 & $8,56 \%$ & $39,81 \%$ & 8 \\
\hline Revisão de Aposentadoria e Pensões & 468 & $0,95 \%$ & $42,39 \%$ & 7 \\
\hline TDA - Títulos da Dívida Agrária & 53 & $0,11 \%$ & $34,48 \%$ & 8 \\
\hline União - Subsidiária & 601 & $1,22 \%$ & $25,05 \%$ & 7 \\
\hline Total & 49451 & $100,00 \%$ & & \\
\hline Média & & & $45,28 \%$ & 8 \\
\hline
\end{tabular}

Fonte: Elaborado pelo autor.

(1) Valores apurados somente nos casos em que a União foi Ré (1-Concordância e 0-Discordância).

(2) Valores em dias corridos e não foram computados os registros sem data de entra e data prazo do advogado que totalizaram 4473 registros.

Com relação ao Percentual Médio de Concordância, ele foi calculado conforme detalhado no item 4.6. Dentre os 24 grupos, apenas 6 mostraram significância para o teste de simetria da distribuição Binomial (Contribuição Social (Inativo); Diferença Verbas SUS; FUNDEF; Planos Bresser, Collor e Verão; Reajuste Salarial 28,86\% (Civil e Militar); TDATítulos da Dívida Agrária).

Apesar desse resultado, entende-se que a média representa uma medida confiável, pois, cada observação tem o mesmo peso, já que, trata-se de uma variável binomial. Verificou-se também que em média a União concordou com os valores solicitados pelas partes em 45,28\% dos pareceres a mediana foi de $42,75 \%$. 
Quanto a variável tempo de elaboração do parecer técnico, novamente utilizou-se a mediana como a medida de tendência central mais representativa das observações, visto que, pelo teste de Kolmogorov-Smirnov, nenhum dos grupos teve essa variável caracterizada como uma distribuição normal. Observou-se que em média (média das medianas) a demanda enviada ao DCP (processo) demora 8 dias corridos para ser analisado e ter o parecer técnico elaborado, corrigido e disponibilizado ao demandante. Ressalta-se que esse valor representa o tempo que o processo ficou no DCP para ser analisado e não apenas o tempo que cada processo levou para ser analisado, ou seja, inclui o tempo que o processo aguarda para ser elaborado.

Partindo para uma análise mais detalhada dos resultados encontrados para os principais objetos da ação verificou-se que no caso da principal demanda ao DCP, as Gratificações de Despenho - Diversas, encontrou-se um valor percentual de 79,76\% de concordância dos pareceres do DCP com os valores pleiteados pelas partes, colocando-o na quarta posição entre os objetos da ação com mais pareceres concordantes. Porém, apesar da importância numérica em relação número de pareceres emitidos pelo DCP, a Margem de Contribuição Direta média - MCDm obtida por parecer técnico para este objeto da ação ficou em R $\$ 90.776,69$ sendo a apenas a $19^{\mathrm{a}}$ maior MCDm dentre 24 objetos da ação, conforme demonstrado na Tabela 4. Analisando-se a MCDm por autor em cada parecer, o valor médio é de R\$17.198,02. Este valor explica-se pelo grande número de autores neste grupo (145.284) que corresponde a 29,28\% do total, sendo o grupo com maior número de partes autoras litigando contra a União. Ele foi responsável por $30,53 \%$ dos processos com mais de 10 autores analisados pelo DCP no período da pesquisa.

É importante ressaltar que a utilização da média como medida de tendência central no caso da MCDm se justifica pelo fato de que os pareceres com as maiores MCDm compensam aqueles que tiveram prejuízos (pareceres concordantes e outros informativos ou devolutivos sem atribuição de valor). Ressalta-se, também, que a demanda enviada ao DCP não sofre uma prévia triagem, gerando assim casos em que o processo fica um bom tempo parado para ser analisado e quando de fato é analisado a solução não requeria necessariamente uma análise técnica, gerando um custo do parecer sem a expectativa de ganho a ele atrelada.

Tentou-se buscar justificativas para o alto grau de concordância dos pareceres que tratam das Gratificações de Desempenho - Diversas, e chegou-se à conclusão de que os cálculos apresentados pelas partes em sua grande maioria realmente apresentavam valores corretos o que pode ser explicado a partir de alguns fatores, dentre eles: 
1) Os cálculos não exigem muita complexidade e conhecimento prévio para serem feitos, já que envolvem em sua maioria a diferença entre pontos ou percentuais atribuídos para os ativos e os pontos recebidos pelos inativos, o que pode ser facilmente achado nas próprias leis que tratam dos Objetos das Ações. Desta forma, as partes autoras podem elaborar as contas sem maiores dificuldades.

2) Devido à grande abrangência, já que afeta a maioria dos inativos do Poder Executivo Federal, um grande número de escritórios de contabilidade e peritos judiciais trabalham nos cálculos destes tipos de processo, disseminando o conhecimento e consequentemente elaborando cálculos precisos de boa qualidade técnica deixando poucas lacunas abertas à críticas pelo DCP. A título de exemplo, atualmente a Justiça Federal do Rio De Janeiro ${ }^{3}$ já disponibiliza na internet planilhas em formato Excel, onde basta ao usuário preencher algumas informações, tais como, o objeto da ação e as datas de citação e atualização, bem como colocar suas informações financeiras para que a planilha gere o valor devido.

Com relação ao tempo médio de elaboração dos pareceres que tratam de Gratificações de Desempenho - Diversas, obteve-se o valor de 14 dias (Tabela 3). Este resultado é reflexo da grande demanda por pareceres que acaba por gerar uma fila de espera para análise dos processos, de forma que o processo passa muito mais tempo aguardando ser analisado do realmente leva para ser analisado.

Seguindo a análise a partir do objeto da ação, a segunda maior demanda do DCP foi a referente ao grupo Reajuste Salarial 28,86\% (Civil e Militar) com 14,82\%. Neste grupo o percentual médio de concordância foi de 49,18\% e o tempo mediano de elaboração foi de 7 dias (Tabela 3). Quanto ao prazo mediano encontrado é importante destacar que os cálculos realizados para o Reajuste Salarial 28,86\% - Civil, contam com auxílio do Sistema SICAP, desenvolvido pelo SERPRO. Tal auxílio não é algo imediato, pois, são lançados, no sistema, os parâmetros, juntamente com os exequentes a terem a conta elaborada e após um período de tempo variável o sistema disponibiliza a conta. A MCDm apurada por parecer foi de $\mathrm{R} \$$ 438.324,63 a $10^{\text {a }}$ maior. Levando-se em conta o número de autores por parecer a MCDm é de $\mathrm{R} \$ 60.662,18$ a $12^{\mathrm{a}}$ maior (Tabela 4).

\footnotetext{
${ }^{3}$ Planilhas disponibilizadas no link http://www.jfrj.jus.br/?id_info=7547.
} 
Tabela 4: Margem de Contribuição Direta - MCD média e mediana do parecer técnico e MCD média e mediana por autor por parecer todas agregadas por Objeto da Ação.

\begin{tabular}{|c|c|c|c|c|}
\hline Objetos da Ação & $\begin{array}{l}\text { Média da MCDm } \\
\text { Mensal por } \\
\text { Parecer }\end{array}$ & $\begin{array}{l}\text { Mediana da } \\
\text { MCDm Mensal } \\
\text { por Parecer }\end{array}$ & $\begin{array}{l}\text { Média da MCDm } \\
\text { Por Autor por } \\
\text { Parecer }\end{array}$ & $\begin{array}{l}\text { Mediana da MCDm } \\
\text { Mensal Por Autor } \\
\text { por Parecer }\end{array}$ \\
\hline Acórdão TCU e Administrativos & $3.435 .944,15$ & $25.461,52$ & $3.416 .871,17$ & $10.456,03$ \\
\hline $\begin{array}{l}\text { Adicional por Tempo de Serviço } \\
\text { (Anuênio / Quinquênio) }\end{array}$ & $236.976,28$ & $9.469,07$ & $40.608,45$ & $2.478,38$ \\
\hline Auxílio Alimentação & $2.045,35$ & $-337,02$ & 283,95 & $-302,87$ \\
\hline Contribuição Social (Inativo) & $5.574,76$ & $-433,30$ & $2.739,33$ & - 77,22 \\
\hline Danos Morais e Materiais & $1.604 .807,91$ & $3.819,83$ & $1.267 .009,56$ & $3.093,98$ \\
\hline $\begin{array}{c}\text { Desapropriação Direta e Indireta } \\
\text { e Reint. De Posse }\end{array}$ & $152.921,94$ & $-376,60$ & $51.383,50$ & $-303,17$ \\
\hline $\begin{array}{c}\text { Diferenças Salariais } \\
\text { (Equiparação, Reenquadramento, } \\
\text { Reintegração) }\end{array}$ & $922.041,01$ & $290.888,63$ & $109.966,01$ & $42.948,54$ \\
\hline Diferenças Verbas SUS & $479.196,11$ & $57.067,82$ & $479.206,73$ & $57.067,82$ \\
\hline FUNDEF & $1.969 .501,52$ & $378.919,74$ & $1.912 .445,41$ & $378.919,74$ \\
\hline $\begin{array}{c}\text { Gratificações de Desempenho - } \\
\text { Diversas }\end{array}$ & $90.776,69$ & $35.209,56$ & $17.198,02$ & $6.823,25$ \\
\hline $\begin{array}{l}\text { Honorários Advocatícios (União - } \\
\text { Autora) }\end{array}$ & $324.687,22$ & $9.233,69$ & $160.573,89$ & $3.973,77$ \\
\hline Indenizações & $2.684 .793,17$ & $238.465,28$ & $1.753 .963,07$ & $76.720,72$ \\
\hline Outros - A especificar & $79.718,76$ & $-465,83$ & $8.340,62$ & $-451,17$ \\
\hline Parcelamento & $15.162,47$ & $5.940,50$ & $10.116,58$ & $3.282,98$ \\
\hline Perícia & $6.015 .519,24$ & $2.980,97$ & $3.574 .635,97$ & $2.980,97$ \\
\hline Planos Bresser, Collor e Verão & $1.031 .456,70$ & $11.984,62$ & $429.179,89$ & $1.162,65$ \\
\hline Quintos/décimos/VPNI & $189.329,43$ & $68.570,28$ & $34.081,49$ & $18.332,46$ \\
\hline $\begin{array}{l}\text { Reajuste - URP Abril/Maio/88 - } \\
16,19 \%\end{array}$ & $106.297,45$ & $-349,59$ & $4.260,05$ & $-4,61$ \\
\hline $\begin{array}{c}\text { Reajuste Conversão URV - } \\
10,94 \% / 11,98 \%\end{array}$ & $188.117,81$ & $110.888,10$ & $38.320,64$ & $21.367,16$ \\
\hline $\begin{array}{c}\text { Reajuste Salarial 28,86\% (Civil e } \\
\text { Militar) }\end{array}$ & $438.324,63$ & $168.305,20$ & $60.662,18$ & $25.265,69$ \\
\hline Resíduo dos 3,17\% (lei 8.880/94) & $124.695,80$ & $38.539,92$ & $8.960,98$ & $4.907,85$ \\
\hline $\begin{array}{c}\text { Revisão de Aposentadoria e } \\
\text { Pensões }\end{array}$ & $353.979,34$ & $128.024,59$ & $133.526,48$ & $42.168,48$ \\
\hline TDA - Títulos da Dívida Agrária & $7.931 .484,66$ & $4.935,25$ & $4.833 .507,12$ & $4.935,25$ \\
\hline União - Subsidiária & $50.333,16$ & $1.352,35$ & $49.939,89$ & 929,85 \\
\hline
\end{tabular}

Fonte: Elaborado pelo autor.

O terceiro maior grupo de demanda do DCP são as Diferenças Salariais (Equiparação, Reenquadramento e Reintegração) com 14,58\%. Neste grupo o percentual médio de concordância foi de $51,80 \%$ e o tempo mediano de elaboração foi de 8 dias. O grupo teve a $8^{\mathrm{a}}$ maior MCDm por parecer R\$922.041,01. Em termos absolutos, esse grupo foi responsável por $32,15 \%$ do montante executado contra a União, o maior dentre os grupos. Ele correspondeu ao 
segundo maior número de autores litigando contra a União (116.207), proporcionando uma a MCDm por autor por parecer de $\mathrm{R} \$ 109.966,01$.

É interessante destacar que o grupo das Diferenças Salariais (Equiparação, Reenquadramento e Reintegração), apresenta normalmente um período de conta mais extenso que os demais grupos. Ele também foi responsável pelo $4^{\circ}$ maior número de processos coletivos com mais 10 autores, analisados pelo DCP, representando 13,17\% do total.

A quarta maior demanda por pareceres é representada pelo grupo que trata do Resíduo dos 3,17\% (Lei 8.880/94) com 8,56\%. Esse grupo foi o $2^{\circ}$ maior responsável por processos com mais 10 autores analisados pelo DCP, representando 23,28\% do Total. O grupo apresentou um percentual médio de concordância foi de 39,81\% e o tempo mediano de elaboração 8 dias. Tal como o grupo Reajuste Salarial 28,86\% (Civil e Militar), esse grupo também tem a disposição para confecção de cálculos o Sistema SICAP. A MCDm por parecer foi de R\$ 124.695,80 a $17^{\mathrm{a}}$ no ranking das maiores. Já quando leva-se em conta o número de autores por parecer ela cai para $20^{\mathrm{a}}$ posição com MCDm de $\mathrm{R} \$ 8.960,98$.

Quanto a quinta maior demanda por pareceres, grupo Honorários Advocatícios (União - Autora), ela representou 3,93\% do total. Este grupo representa os processos contra a União julgados improcedentes pela Justiça, e onde a União vem requerer honorários advocatícios dos autores. A MCDm por parecer foi de $\mathrm{R} \$ 324.687,22$, já a MCDm por autor por parecer foi de $\mathrm{R} \$ 160.573,89$ a $9^{\mathrm{a}}$ maior. O tempo mediano de elaboração do parecer foi de 7 dias. Neste grupo o cálculo realizado pelo DCP é em sua maioria a aplicação de um percentual sobre o valor pleiteado pelos autores ou sobre o valor da causa, com posterior atualização monetária.

A sexta maior demanda trata das Indenizações e corresponde a 2,70\% dos pareceres emitidos. Ela possui a $4^{\mathrm{a}}$ maior MCDm por pareceres técnicos - R $\$ 2.684 .793,17$. O percentual médio de concordância dos pareceres com os valores pleiteados pelos autores foi de 55,23\% sendo e o tempo mediano de elaboração foi de 6 dias. Quando se leva em conta o número de autores por parecer a MCDm é de R\$ $1.753 .963,07$ a $5^{\mathrm{a}}$ maior.

O sétimo grupo com maior demanda por pareceres foi o grupo Perícia com 2,07\%. Ele foi o grupo com o segundo menor percentual de pareceres concordantes emitidos $23,40 \%$. No cálculo do tempo mediano de elaboração verificou-se o incrível valor de 3 dias. Uma análise mais detalhada, mostrou que dos 1025 registros no Atuação 976 não continham todas as informações necessárias para cálculo do prazo. Portanto, este prazo foi reflexo de apenas 49 registros o que não representa a realidade. No tocante a MCDm por parecer, o grupo perícia 
teve a $2^{\mathrm{a}}$ maior, com o valor de $\mathrm{R} \$ 6.015 .519,24$. Levando-se em conta o número de exequentes por parecer o valor cai para $\mathrm{R} \$ 3.574 .635,97$ sendo a $2^{\mathrm{a}}$ maior $\mathrm{MCDm}$ por autor por parecer (Tabela 5).

Verificadas as sete maiores demandas por pareceres técnicos passa-se a olhar para três demanda pouco expressivas em quantidade, porém com grande MCDm por parecer.

Tabela 5: Ranking das 10 maiores Margens de Contribuição Direta Média - MCDm por parecer e por quantidade média de autores por parecer.

\begin{tabular}{|c|c|c|c|c|}
\hline Ordem & Objetos da Ação & $\begin{array}{l}\text { Média da MCDm } \\
\text { Mensal por Parecer }\end{array}$ & Objetos da Ação & $\begin{array}{c}\text { Média da MCDm Mensal Por } \\
\text { Autor por Parecer }\end{array}$ \\
\hline 1 & $\begin{array}{l}\text { TDA - Títulos da } \\
\text { Dívida Agrária }\end{array}$ & $7.931 .484,66$ & $\begin{array}{l}\text { TDA - Títulos da } \\
\text { Dívida Agrária }\end{array}$ & $4.833 .507,12$ \\
\hline 2 & Perícia & $6.015 .519,24$ & Perícia & $3.574 .635,97$ \\
\hline 3 & $\begin{array}{l}\text { Acórdão TCU e } \\
\text { Administrativos }\end{array}$ & $3.435 .944,15$ & $\begin{array}{l}\text { Acórdão TCU e } \\
\text { Administrativos }\end{array}$ & $3.416 .871,17$ \\
\hline 4 & Indenizações & $2.684 .793,17$ & FUNDEF & $1.912 .445,41$ \\
\hline 5 & FUNDEF & $1.969 .501,52$ & Indenizações & $1.753 .963,07$ \\
\hline 6 & $\begin{array}{l}\text { Danos Morais e } \\
\text { Materiais }\end{array}$ & $1.604 .807,91$ & $\begin{array}{l}\text { Danos Morais e } \\
\text { Materiais }\end{array}$ & $1.267 .009,56$ \\
\hline 7 & $\begin{array}{l}\text { Planos Bresser, Collor e } \\
\text { Verão }\end{array}$ & $1.031 .456,70$ & Diferenças Verbas SUS & $479.206,73$ \\
\hline 8 & $\begin{array}{l}\text { Diferenças Salariais } \\
\text { (Equiparação... }\end{array}$ & $922.041,01$ & $\begin{array}{l}\text { Planos Bresser, Collor e } \\
\text { Verão } \\
\text { Honorários }\end{array}$ & $429.179,89$ \\
\hline 9 & Diferenças Verbas SUS & $479.196,11$ & $\begin{array}{l}\text { Advocatícios (União - } \\
\text { Autora) }\end{array}$ & $160.573,89$ \\
\hline 10 & $\begin{array}{l}\text { Reajuste Salarial } \\
28,86 \% \text { (Civil e } \\
\text { Militar) } \\
\end{array}$ & $438.324,63$ & $\begin{array}{l}\text { Revisão de } \\
\text { Aposentadoria e } \\
\text { Pensões } \\
\end{array}$ & $133.526,48$ \\
\hline
\end{tabular}

Fonte: Elaborado pelo autor.

O grupo de menor representatividade percentual da demanda por pareceres foi o grupo dos TDA- Títulos da Dívida Agrária com 0,11\% do total de pareceres emitidos. Entretanto, tal grupo merece destaque, pois, apresentou a maior MCDm por parecer $\mathrm{R} \$ 7.931 .484,66$, conforme Tabela 5. Quando leva-se em conta o número de autores por parecer esse valor cai para $\mathrm{R} \$ 4.833 .507,12$ mas ainda mantêm o primeiro lugar dentre os grupos. Neste grupo é onde verifica-se a maior disparidade entre a média e a mediana, isso decorre devido ao número de títulos que cada processo envolve, indo desde de um título a centenas de títulos nos casos envolvendo instituições financeiras como autoras. O percentual de concordância com os cálculos apresentados pelos autores foi de $34,48 \%$, o quarto mais baixo dentre os objetos da ação. O alto percentual de discordância reside em sua maioria no tocante a elaboração dos cálculos pelo DCP a partir de parâmetros definidos em teses jurídicas. O prazo mediano de elaboração do parecer é de 8 dias. 
A terceira maior MCDm por parecer técnico (a segunda foi do grupo Perícia $7^{\mathrm{a}}$ maior demanda) pertence ao grupo Acórdão TCU e Administrativos. Neste grupo verificou-se uma MCDm média por parecer de R 3.435.944,15, que reduz levemente para R 3.416.871,17 quando analisa-se a partir do número de autores por parecer. É neste grupo que se incluem uma parte das ações de cobrança do Tribunal de Contas da União - TCU, ou seja, onde a União é autora, isso justifica o percentual de concordância $0,00 \%$ na Tabela 3. Com relação ao tempo mediano de 7 dias para elaboração do parecer é interessante citar que apesar do TCU disponibilizar em sua página na internet um sistema para atualização de contas, proporcionando celeridade ao trabalho do DCP, os demais objetos de ação pertencentes ao grupo não possuem sistemas auxiliares. Apesar da relevância da MCDm por parecer, esse grupo foi responsável apenas por $0,51 \%$ da demanda ao DCP.

A quinta maior MCDm observada (a quarta foi do grupo Indenizações $6^{\mathrm{a}}$ maior demanda) foi referente aos pareceres que tratam do FUNDEF. Este grupo foi responsável por 0,17\% dos pareceres emitidos, a terceira menor demanda. O prazo mediano de elaboração do parecer foi de 13 dias. A MCDm média de cada parecer ficou em $\mathrm{R} \$ 1.969 .501,52$ e a MCDm média por autor ficou em $\mathrm{R} \$ 1.912 .445,41$.

Desta forma, apesar de ter sido verificado na Tabela 4, alguns valores medianos negativos para a MCDm do parecer, quando tratou-se da média, todos os grupos de objetos da ação mostraram MCDm positiva e acima de $\mathrm{R}$ \$2.045,35. Considerando o número de autores por parecer a MCDm média mínima encontrada foi de R\$283,95.

\subsubsection{Análise por Tipos de Cálculo}

Partindo-se agora para análise de dados levando-se em conta o Tipo de Cálculo do parecer técnico, verificou-se a partir da Tabela 6 que: 37,50\% dos pareceres foram referentes a Impugnação de Valores; 17,71\% à Conferência e Manifestação Técnica; Propositura de Ação - Auto Execução representaram 13,04\%; Apuração de PSS foi responsável por 7,80\% e; Atualização de conta representou 6,50\%. Assim as cinco maiores demandas foram responsáveis por $82,55 \%$ da demanda total.

A Tabela 6 também apresenta o percentual médio de concordância que neste caso ficou em 46,73\%. Tal percentual é bem próximo do verificado na Tabela 3 (45,28\%). A pequena diferença encontrada pode ser explicada pela utilização da própria média, que na Tabela 3 leva em conta 24 observações e nesta Tabela 6 leva em conta apenas 12. Outro ponto que pode ter influenciado é que realizando a análise a partir do objeto da ação não é possível identificar os 
casos em que apesar da União ser a Ré ela apresenta a conta para a parte autora e assim o registro no Atuação entra com valores iguais para a parte autora e para a União. Os tipos de cálculo Acordos e Transações, e Pedidos Totalmente Procedentes estão zerados, pois, nestes casos a conta é elaborada pela União apesar de ser Ré. Para o grupo Propositura da Ação - Auto Execução, os valores zerados são decorrência da União ser a Autora.

Tabela 6: Quantidade Pareceres Emitidos por Tipo de Cálculo, Percentual de Representatividade, Percentual Médio de Concordância e Mediana do Tempo de Elaboração.

\begin{tabular}{lrrrc}
\hline \multicolumn{1}{c}{ Tipos de Cálculo } & $\begin{array}{c}\text { Contagem Tipos } \\
\text { de Cálculo }\end{array}$ & $\begin{array}{c}\text { Percentual de } \\
\text { Representatividade }\end{array}$ & $\begin{array}{c}\text { Percentual } \\
\text { Médio de } \\
\text { Concordância } \\
\text { (1) }\end{array}$ & $\begin{array}{c}\text { Mediana do } \\
\text { Tempo de } \\
\text { Elaboração } \\
\text { (2) }\end{array}$ \\
\hline Acordo e transações & 1231 & $2,49 \%$ & $0,00 \%$ & 3 \\
Apuração PSS & 3858 & $7,80 \%$ & $88,39 \%$ & 9 \\
Atualização de Conta & 3213 & $6,50 \%$ & $68,56 \%$ & 7 \\
Cálculos Periciais & 884 & $1,79 \%$ & $75,54 \%$ & 5 \\
Conferência e Manifest. Técnica & 8758 & $17,71 \%$ & $60,64 \%$ & 7 \\
Embargos (Art. 730 - CPC) & 2803 & $5,67 \%$ & $15,27 \%$ & 9 \\
Hon. Advocatícios e Periciais & 1512 & $3,06 \%$ & $37,50 \%$ & 7 \\
Impugnação de Valores & 18545 & $37,50 \%$ & $58,62 \%$ & 11 \\
Liquidação de sentença & 1099 & $2,22 \%$ & $77,71 \%$ & 11 \\
Pedidos Totalmente Improcedentes & 452 & $0,91 \%$ & $0,00 \%$ & 14 \\
Precatórios & 647 & $1,31 \%$ & $78,54 \%$ & 5 \\
Propositura de Ação - Auto Execução & 6449 & $13,04 \%$ & $0,00 \%$ & 11 \\
\hline Total & $\mathbf{4 9 4 5 1}$ & $\mathbf{1 0 0 , 0 0 \%}$ & - & $\mathbf{-}$ \\
\hline Média & - & $\mathbf{4 6 , 7 3 \%}$ & $\mathbf{8}$ \\
\hline Fonte: Elabor & & & \\
\hline
\end{tabular}

Fonte: Elaborado pelo autor.

(1) Valores apurados somente nos casos em que a União foi Ré (100\% Concordância e 0\% Discordância).

(2) Valores em dias corridos e não foram computados os registros sem data de entra e data prazo do advogado totalizando 4473 registros.

A média do prazo mediano de elaboração do parecer técnico ficou em 8 dias confirmando o valor apresentado na Tabela 3.

Uma atenção especial deve ser dada a sexta maior demanda, Embargos (Art. 730 - CPC) com 5,67\%, pois, foi nela que verificou-se o menor percentual de pareceres concordantes 15,27\%. É também, neste tipo de cálculo, que o DCP expressa sua maior independência em relação a área jurídica, destacando o papel do Contador e outros profissionais da área. Isso ocorre, pois, em tese nesta fase, o processo chega ao DCP com quase todas as alegações jurídicas já discutidas e definidas na primeira sentença, restando, portanto, as alegações técnicas, caso haja, que nortearão as discussões jurídicas futuras no processo. 
Quanto a MCDm por parecer, os Embargos (Art. 730 - CPC) apresentaram o terceiro maior valor $\mathrm{R} \$ 1.618 .830,18$, conforme Tabela 7 . Levando-se em conta o número de autores por parecer o valor médio caiu para 102.942,09, sexto maior valor. O prazo mediano de elaboração do parecer ficou em 9 dias.

Outro tipo de cálculo que merece destaque, e que é a segunda maior MCDm média por parecer R\$2.244.080,32, é o grupo Propositura de Ação - Auto Execução. Esse grupo representa os cálculos que tem a União como parte autora, ou seja, são processos em que a União busca o ressarcimento, por exemplo, de danos ao erário, como nas condenações do Tribunal de Contas da União. Isso dá sinais da mudança que vem gradativamente ocorrendo na AGU, passando de uma mera defensora do erário, para também ser uma "arrecadadora" de recursos para a União. A demanda por pareceres deste grupo representou 13,04\% do total e o prazo mediano de elaboração do parecer ficou em 11 dias. Quando analisada a partir da MCDm média por autor por parecer, o grupo obteve a terceira maior MCDm.

Tabela 7: MCD média e mediana do parecer técnico e MCD média e mediana por autor por parecer todas agregadas por Tipo de Cálculo.

\begin{tabular}{lrrrr}
\hline \multicolumn{1}{c}{ Tipo de Cálculo } & $\begin{array}{c}\text { Média da MCDm } \\
\text { Mensal do } \\
\text { Parecer }\end{array}$ & $\begin{array}{c}\text { Mediana da } \\
\text { MCDm Mensal } \\
\text { do Parecer }\end{array}$ & $\begin{array}{c}\text { Média da MCDm } \\
\text { Mensal Por Autor } \\
\text { por Parecer }\end{array}$ & $\begin{array}{c}\text { Mediana da } \\
\text { MCDm Mensal } \\
\text { Por Autor por } \\
\text { Parecer }\end{array}$ \\
\hline Acordo e transações & $30.710,82$ & $-386,61$ & $27.951,31$ & $-16,89$ \\
Apuração PSS & 598,57 & $-386,61$ & 98,18 & $-91,76$ \\
Atualização de Conta & $1.285 .671,21$ & $60.856,56$ & $573.466,07$ & $6.629,13$ \\
Cálculos Periciais & $820.788,99$ & $-266,95$ & $448.535,11$ & $-133,48$ \\
Conferência e Manifest. Técnica & $201.241,97$ & $68.483,11$ & $13.564,81$ & $7.269,69$ \\
Embargo (Art. 730 - CPC) & $1.618 .830,18$ & $865.756,53$ & $102.942,09$ & $69.899,67$ \\
Hon. Advocatícios e Periciais & $918.441,42$ & $5.470,98$ & $908.905,32$ & $1.823,66$ \\
Impugnação de Valores & $709.813,10$ & $236.120,19$ & $52.939,77$ & $30.947,81$ \\
Liquidação de sentença & $99.674,03$ & $7.524,06$ & $37.215,33$ & $4.056,39$ \\
Pedidos Totalmente Improcedentes & $5.264 .348,82$ & $-411,03$ & $1.237 .271,68$ & $-41,17$ \\
Precatórios & $73.501,34$ & 889,31 & $21.405,58$ & 155,92 \\
Propositura de Ação - Auto Execução & $2.244 .080,32$ & $1.595,30$ & $770.636,88$ & 531,77 \\
\hline
\end{tabular}

Fonte: Elaborado pelo autor.

Apesar da alta MCDm apresentada pelo grupo Pedidos Totalmente Improcedentes, ele não será alvo de analise neste trabalho por se tratar de uma estimativa de ganho, ou seja, o quanto a União deixou de pagar já que o processo foi julgado improcedente.

\subsubsection{Análise do Valor Individual Executado}

Devido à grande diversidade e amplitude dos valores pleiteados nos processos que chegam para análise no DCP, tomou-se como primeira medida para redução da amplitude existente, a criação de uma nova variável chamada "valor por autor" que é o resultado da divisão 
entre a variável "valor autor" pela variável "quantidade de exequentes", isso no caso da União ser a Ré. Caso a União configure como Autora, a variável, assume o resultado da divisão "Valor União" pela variável "quantidade de exequentes".

Desta forma esperava-se uma maior aproximação dos dados levando-se em conta o valor individual de cada autor por processo, porém, ao apurar as medidas de tendência central, de dispersão, de distribuição e os percentis, dispostos no Quadro 4, verificou-se a existência de duas realidades antagônicas.

Quadro 4: Resultados das estatísticas descritivas para a variável Valor por Autor.

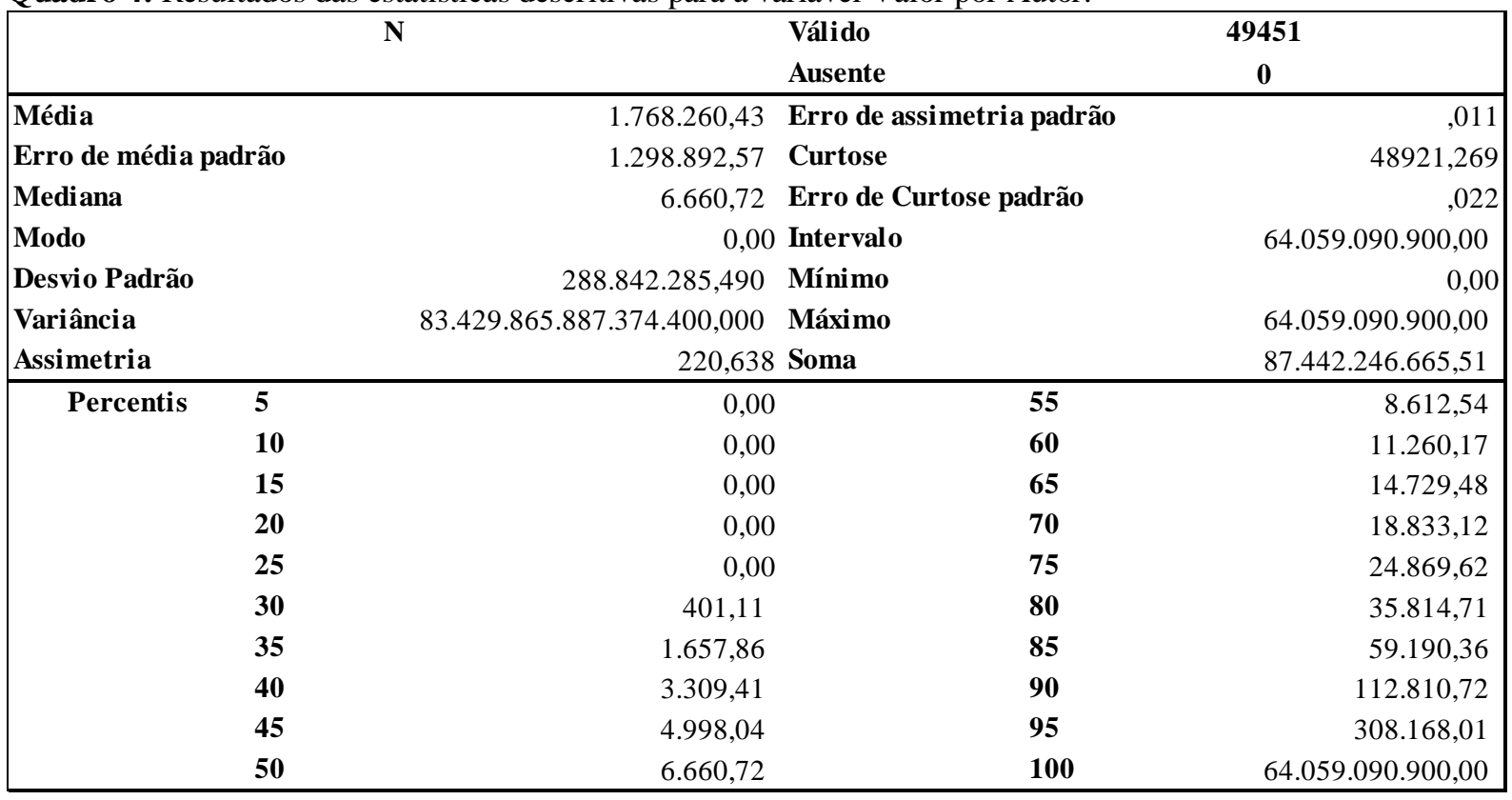

Fonte: Elaborado pelo autor a partir de dados do SPSS.

Por um lado tem-se que mais de $25 \%$ das observações possuem valor nulo para a variável em análise. Grande parte desse resultado deve-se ao fato que, pareceres Informativos e Devolutivos que representam $22,59 \%$ do total de pareceres, em sua grande maioria, não apresentam um valor para execução. O restante, pode ser atribuído a falhas no registro dos valores, e também a classificação equivocada do campo tipo de parecer (item 9 - Tabela 1).

No outro extremo, verificou-se uma observação ${ }^{4}$ maior do que soma de todas as demais observações. Após análise externa ao Atuação, constatou-se que ela estava registrada corretamente, entretanto, sua permanência dentre as observações levaria a estatísticas descritivas que não refletiriam a rotina diária do DCP. Desta forma o outlier foi retirado da

\footnotetext{
${ }^{4}$ É importante informar que a observação retirada não representa um parecer complexo, mas apenas um valor esdrúxulo de honorários a favor da União e de um Ex-Presidente da República que foi originado de um valor da causa superior a Cr\$ 100.000.000.000.000,00.
} 
análise juntamente com as observações com valores zerados. O resultado das estatísticas descritivas no novo cenário está detalhando no Quadro 5.

Quadro 5: Resultados das estatísticas descritivas para a variável Valor por Autor após retirada de valores zerados e de um outlier.

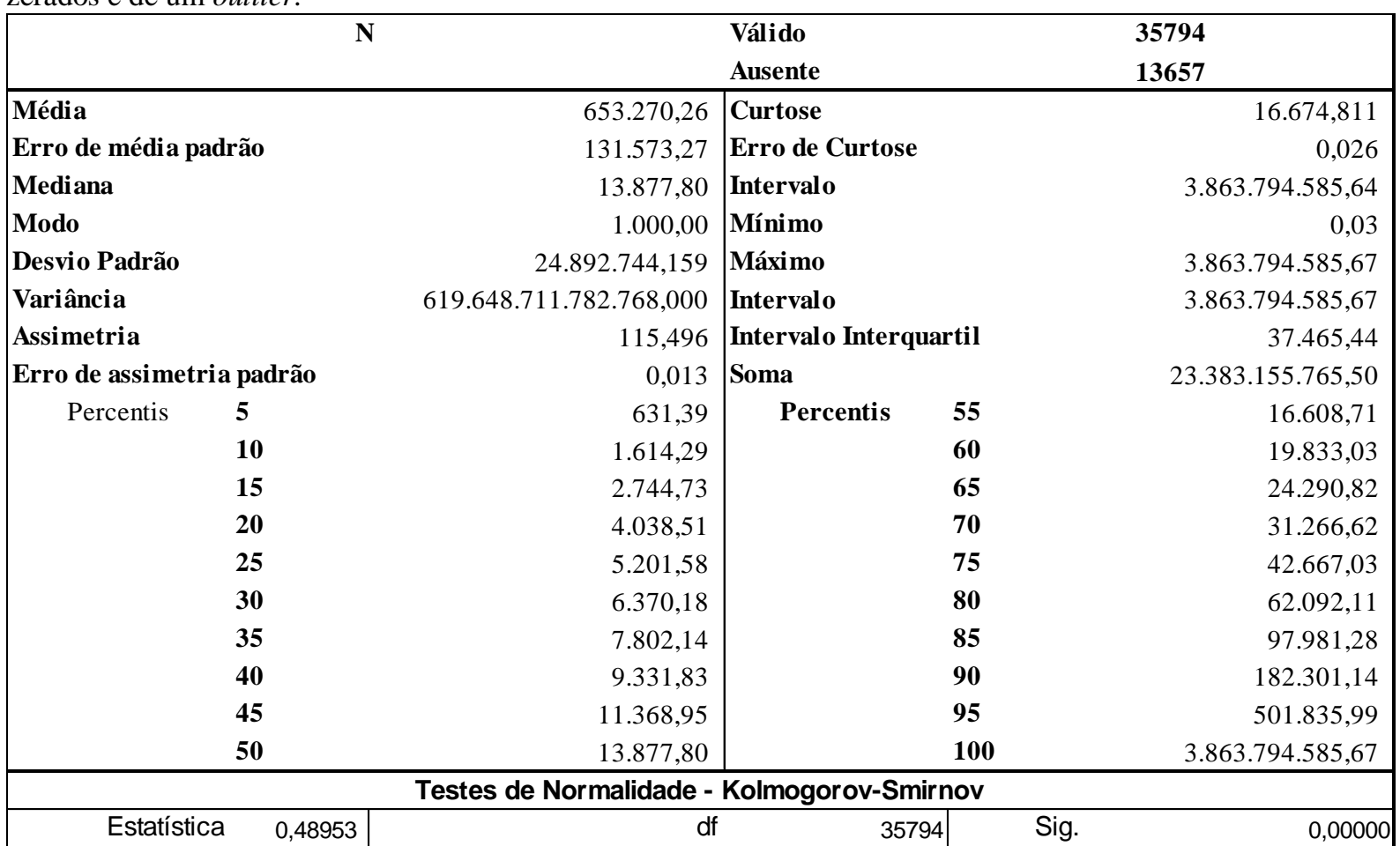

Fonte: Elaborado pelo autor a partir de dados do SPSS.

Após a retirada dos valores zerados e do outlier citado anteriormente, buscou-se, com auxílio do programa SPSS, realizar um agrupamento das observações da variável Valor Por Autor.

Tanto os métodos hierárquicos de agrupamento (Ligação entre grupos, vizinho mais próximo, vizinho mais distante, centroide, mediano e Ward) quanto o método não-hierárquico (k-média) não apresentaram resultados de agrupamentos que refletisse de forma interessante as diversas realidades observadas. Um dos possíveis motivos para a não adequação dos métodos de agrupamento, pode ser devido à grande amplitude da variável, já que os valores partiram de $\mathrm{R} \$ 0,03$ até $\mathrm{R} \$ 3.863 .794 .585,67$.

Desta forma optou-se por realizar um agrupamento partindo-se da distribuição de frequência dos valores observados. No Quadro 5 verifica-se essa distribuição com base em 20 divisões. Pode-se notar que aproximadamente $60 \%$ das observações ${ }^{5}$ estão abaixo dos R\$ 20.000,00, que hoje é utilizado como parâmetro para que o analista/técnico assine o Parecer sem precisar necessariamente de revisão da chefia imediata. Outro, ponto interessante é que nos

\footnotetext{
${ }^{5}$ É importante relembrar que esse valor é sobre 35740 observações, ou seja, já foram retiradas aproximadamente $25 \%$ de observações zeradas e um outilier.
} 
últimos 5\% encontramos a maior variação e amplitude das observações, o que pode sugerir uma atenção especial a esse percentil.

Quanto ao teste de normalidade, verificou-se que o teste de Kolmogorov-Smirnov apresentou o valor de $p$-value de 0,000 , para um nível de significância de 95\%, indicando a não normalidade das observações da variável Valor por Autor.

Para as observações da variável Valor por Autor, o SPSS não apresentou o teste de Shapiro-Wilk, pois, conforme afirmado por Shapiro e Wilk (1965) o teste não é eficiente para amostras grandes, neste caso 35794 observações, pois ele pode ser inadequado para tabular ou aproximar os valores dos multiplicadores do numerador da estatística. Além disso pode ser difícil para grandes amostras a determinação dos pontos percentuais da sua distribuição (SHAPIRO e WILK, 1965).

Assim, devido a não normalidade das observações, é temerário tomar como referência a média apresentada no Quadro 5, sendo, portanto, o valor da mediana $\mathrm{R} \$ 13.877,80$ o mais adequando para representar o valor médio por pessoa que é executado contra a União.

Quadro 6: Valores executados por autor, excesso médio apurado por autor, custo médio do parecer por autor e MCDm por autor, distribuídos em 20 classes de igual frequência.

\begin{tabular}{|rrrrrrr|}
\hline $\mathbf{N}^{\mathbf{0}}$ & \multicolumn{1}{c}{ Classe } & Limite Superior & $\begin{array}{c}\text { Excesso médio Por } \\
\text { Autor da Classe }\end{array}$ & $\begin{array}{c}\text { Custo por Parecer por } \\
\text { Média de Autor }\end{array}$ & $\begin{array}{c}\text { MCDm } \\
\text { por } \\
\text { Autor }\end{array}$ & $\begin{array}{c}\text { Percentual de } \\
\text { Concordância }\end{array}$ \\
\hline 1 & $0---5 \%$ & 631,47 & 137,56 & 21,56 & $84,33 \%$ & $77,69 \%$ \\
2 & $5---10 \%$ & $1.617,07$ & 332,15 & 90,55 & $72,74 \%$ & $76,65 \%$ \\
3 & $10---15 \%$ & $2.747,97$ & 587,07 & 90,55 & $84,58 \%$ & $74,24 \%$ \\
4 & $15---20 \%$ & $4.038,95$ & 419,93 & 113,19 & $73,04 \%$ & $77,86 \%$ \\
5 & $20---25 \%$ & $5.201,88$ & 440,10 & 37,73 & $91,43 \%$ & $77,05 \%$ \\
6 & $25---30 \%$ & $6.370,92$ & 536,03 & 113,19 & $78,88 \%$ & $76,55 \%$ \\
7 & $30---35 \%$ & $7.801,60$ & $1.136,63$ & 50,31 & $95,57 \%$ & $69,18 \%$ \\
8 & $35---40 \%$ & $9.331,47$ & $1.220,04$ & 41,16 & $96,63 \%$ & $69,90 \%$ \\
9 & $40---45 \%$ & $11.367,49$ & $1.219,88$ & 90,55 & $92,58 \%$ & $72,90 \%$ \\
10 & $45---50 \%$ & $13.865,23$ & $1.603,64$ & 64,68 & $95,97 \%$ & $72,41 \%$ \\
11 & $50---55 \%$ & $16.597,15$ & $1.452,86$ & 113,19 & $92,21 \%$ & $75,30 \%$ \\
12 & $55---60 \%$ & $19.805,65$ & $1.817,98$ & 37,73 & $97,92 \%$ & $70,97 \%$ \\
13 & $60---65 \%$ & $24.242,54$ & $2.730,30$ & 90,55 & $96,68 \%$ & $69,40 \%$ \\
14 & $65---70 \%$ & $31.190,22$ & $4.524,68$ & 64,68 & $98,57 \%$ & $63,80 \%$ \\
15 & $70---75 \%$ & $42.548,44$ & $6.462,11$ & 75,46 & $98,83 \%$ & $59,30 \%$ \\
16 & $75---80 \%$ & $61.887,50$ & $13.556,93$ & 50,31 & $99,63 \%$ & $47,24 \%$ \\
17 & $80---85 \%$ & $97.532,39$ & $16.681,83$ & 64,68 & $99,61 \%$ & $49,60 \%$ \\
18 & $85---90 \%$ & $181.847,91$ & $36.698,66$ & 22,64 & $99,94 \%$ & $43,11 \%$ \\
19 & $90---95 \%$ & $495.546,23$ & $94.102,77$ & 75,46 & $99,92 \%$ & $35,78 \%$ \\
20 & $95---100 \%$ & $3.863 .794 .585,67$ & $6.692 .034,29$ & 226,39 & $99,997 \%$ & $27,77 \%$ \\
\hline
\end{tabular}

Fonte: Elaborado pelo autor.

(1) Custo médio apurado em valores correntes.

(2) Valores apurados somente nos casos em que a União foi Ré (1-Concordância e 0-Discordância). 
Já para representar o valor da MCDm por autor, a média é uma medida representativa, pois, neste caso, os processos de menor MCDm são compensados por outros com maior MCDm. Desta forma o Quadro 6 apresenta o excesso de execução médio por autor para cada um dos 20 percentis do Quadro 5, que aqui são tratados como classes.

O Quadro 6 mostra que nas 6 primeiras classes, onde o excesso médio apurado por autor ficou abaixo dos $\mathrm{R} \$ 600,00$, apenas a quinta classe $(\mathrm{R} \$ 4.038,96$ até $\mathrm{R} \$ 5.201,88)$ apresentou uma MCDm por autor maior que 90\%, tal como nas classes de 7 a 20. A MCDm por autor menos elevada, nas seis primeiras classes, pode ser explicada pelo maior percentual de pareceres concordantes. O coeficiente de correlação linear de Pearson, entre a MCDm por autor e o percentual de concordância, foi -0,6394 indicando uma correlação negativa moderada entre as variáveis.

Essa menor MCDm nos casos em que o autor executa um valor menor, já era previsto, pois, se for levado em conta o custo de oportunidade de uma pessoa processar a União, verificase que uma pessoa, com preferências normais e avessa ao risco, só irá de fato dar continuidade a lide se tiver elementos e convicções de sucesso no seu pleito.

Como exemplo de critérios, que podem ser levados em conta, por uma pessoa na formação do custo de oportunidade de entrar com um processo contra a União têm-se:

1. Custo do tempo de providenciar um advogado que aceite a causa;

2. Honorários do Advogado;

3. Custas iniciais do processo, a depender do acordo de remuneração do advogado;

4. Custo do tempo de confeccionar uma petição, nos casos em que a pessoa possa processar a União sem necessariamente ter um advogado (Juizados Especiais);

5. Mensalidade do sindicato ou associação, nos casos de ações coletivas organizadas por essas instituições;

6. Custo da frustação de ter o pleito indeferido e acabar tendo que pagar honorários advocatícios para União.

O trabalho de Machado (2011) trata com maiores detalhes do custo de oportunidade da concordância com os valores propostos pela União, isso para aqueles autores que entraram com processos contra a União pelo Juizado Especiais. 


\section{CONCLUSÕES}

Esse trabalho teve como objetivo identificar o custo médio do parecer técnico emitido pelo Departamento de Cálculos e Perícias da Advocacia-Geral da União, utilizando para isso o método de custeio direto, conforme conceituado em Machado (2002) e buscando verificar a diferença percentual desse método de custeio em relação a não inclusão dos custos indiretos. Além disso buscou-se como objetivos específicos a identificação de elementos que municiassem os gestores do DCP com valores numéricos sobre os trabalhos desempenhados, proporcionando a criação futura de indicadores de eficiência e colaborando na tomada de decisões sobre o departamento.

A escolha pelo método de custeio direto se deu pela importância recente dada a este método nos trabalhos realizados pelo Governo Federal para a implantação do SIC, e também, por não ter sido encontrado na literatura brasileira trabalhos que abordassem esse método de forma prática.

A utilização do método direto gerou algumas limitações no escopo deste trabalho como: a não apuração do custo do tempo ocioso que o parecer técnico aguarda para ser analisado e também o não computo do equivalente de produção.

Quanto aos resultados encontrados, verificou-se um custo médio por parecer de $\mathrm{R} \$ 547,25$ com mediana de $\mathrm{R} \$ 498,53$ ambos em valores de janeiro de 2015. Esses valores proporcionaram um primeiro norte onde sugere-se que o DCP se abstenha de analisar processos onde o valor total seja abaixo de $\mathrm{R} \$ 498,53$ (mediana), pois, o custo benefício é zero, além disso, processos abaixo desse valor representam apenas $1,2 \%$ da média mensal demandada tendo um impacto financeiro desprezível e a probabilidade média de concordância com valores até esse montante é de $90 \%$.

Quando se leva em consideração os custos indiretos calculados pelo método absorção rateados pela área ocupada pelo DCP no edifício Sede I da AGU, verificou-se uma "perda média de informação" no valor dos custos de no mínimo $20,71 \%$ no período de janeiro de 2014 a julho de 2014, devendo-se boa parte desse percentual, ao aluguel do edifício Sede I. Cabe aqui ressaltar que não foram incluídos nos custos indiretos, os custos referentes aos setores de serviços da AGU (ex. RH e contabilidade) que dão suporte a todos os demais setores da AGU, sendo portanto uma limitação deste trabalho. 
Com relação ao aluguel, maior custo indireto observado, a lacuna deixada pela utilização do método direto, pode não se refletir em outros entes da administração pública que possuam sede própria.

Esse impacto dos custos indiretos (alugueis e outros custos) em geral começa a diminuir conforme os custos vão sendo agregados, aumentando o nível da estrutura do ente público, ou seja, em menores níveis de detalhamento o método de custeio direto é bastante representativo, de forma que os gestores de alto escalão podem utilizá-lo de forma segura para comparações entre serviços prestados por diferentes entidades da administração pública e até em relação a entidades privadas.

Apesar da falta de comparação com os resultados obtidos neste trabalho, visto que, não foram encontrados trabalhos que abordassem o método de custeio direto de forma aplicada, entende-se que esse método é bastante interessante, também, para os gestores de baixo escalão, pois, ele é um ferramental fácil de ser utilizado na prática, já que para a grande maioria dos entes públicos, a remuneração dos servidores é uma parcela extremamente significativa dos custos do ente público, além do que com a evolução da legislação que trata da transparência dos gastos públicos, a remuneração dos servidores é fácil de ser obtida.

Quanto a Margem de Contribuição Direta média - MCDm do parecer técnico por objeto da ação, verificou-se que em regra as menores demandas, que representam menos de $10 \%$, são responsáveis pelas maiores MCDm por parecer. A partir da análise dos dados do Atuação não pode-se inferir uma justificativa segura para o grande excesso (MCDm) apurado mas, suspeitase de que as partes autoras, de uma forma geral, não se preocupem muito com os critérios efetivamente determinados pela legislação e apresentem cálculos com valores um pouco mais elevados que o efetivamente devido, na intenção de que tais equívocos não sejam identificados pela União, seja pela complexidade do cálculo e curto prazo para sua análise, seja pela apresentação pouco detalhada do cálculo ou também pelo decurso de prazos judiciais sem que a União possa realizar uma boa defesa e em um segundo momento os parâmetros de cálculo não possam ser mais discutidos.

Já com relação ao Tipo de Cálculo, os resultados mostraram que devem ser priorizados os processos que estão na fase de Embargos (Art. 730 - CPC), pois, eles apresentam a terceira maior MCDm por parecer $\mathrm{R}$ \$ 1.618.830,18 além de terem o menor percentual de concordância 15,27\%. Devido a importância desse tipo de cálculo nos rumos das discussões jurídicas que o processo passa a ter a partir de então, seria uma oportunidade interessante verificar o quanto 
um aumento na qualidade (por exemplo, maior número de alegações) do parecer técnico, neste tipo de cálculo, poderá diminuir demandas futuras, em outros tipos de cálculo para esse mesmo processo.

Portanto, verificou-se que o método direto não é um método totalmente eficaz para o cálculo de custos de unidades orçamentarias que compartilhem custos indiretos com outras. Porém, a "perda média de informação" de custos, que neste trabalho apuramos em no mínimo $20,71 \%$, pode ser compensada pela facilidade na aplicação do método e consequente rapidez na realização dos cálculos.

Assim, o método de custeio direto provê os gestores de informações de forma rápida e dentro de um bom nível de confiabilidade, proporcionando ganho de tempo de forma que esses gestores possam tomar as medidas mais célere evitando um maior consumo de gastos públicos desnecessários.

É importante ressaltar que os custos apurados através do Método de Custeio Direto com base nos valores do Sistema de Informações de Custos do Governo Federal - SIC, estão sobre a ótica do regime de caixa.

Espera-se que este trabalho possa contribuir para a evolução da apuração dos custos no Governo Federal, pois, apesar do método de custeio direto apresentar um bom custo benefício para o Governo, as informações geradas por ele são passíveis de críticas se usadas sem as ressalvas pertinentes. Outro ponto a ser criticado é que em algum momento o gestor irá se deparar como custos indiretos e neste ponto o método de custeio direto necessitará da complementação de outro método que trate os custos indiretos. Um ponto a ser discutido em um futuro breve pode ser a escolha do método adequado (custo benefício, representação fiel da realidade) para tratar os custos indiretos dos serviços.

Como indicação de trabalhos complementares, sugere-se que sejam realizadas pesquisas em outros entes públicos comparando o percentual de informação omitida pela utilização do método de custeio direto com outros métodos de custeio de forma que no futuro possa ser elaborado um indicador de quanto um servidor público (custo direto) tem seu equivale em gastos indiretos o que dará aos gestores uma melhor noção dos custos de contratação de mais servidores públicos. 


\section{REFERÊNCIAS}

ATUAÇÃO. Banco de Dados do Departamento de Cálculos e Perícias da Advocacia-Geral da União. Acesso em: 27 agosto 2014.

ABBAS, K.; GONÇALVES, M. N.; LEONICE, M. Os métodos de custeio: Vantagens, desvantagens e sua aplicabilidade nos diversos tipos de organizações apresentadas pela literatura. Revista Contexto. UFRGS, Porto Alegre, v. 12, n. 22, p. 145-159, jul/dez. 2012.

ALONSO, Marcos. Custos no Serviço Público. Revista do Serviço Público. ENAP. Brasília, Ano 50, n. 1, p. 37-63, jan/mar. 1999.

BORGES, T. B.; MATIAS, M. A. Contabilidade Gerencial no setor público: o caso de Minas Gerais. Revista Contabilidade Vista e Revista. UFMG, Belo Horizonte, v. 22, n. 3, p. 73-98, jul/set. 2011.

BRASIL. Sistema de Custos do Governo Federal: O que é? Para que serve? E como isso afeta meu dia a dia? Brasília: MF, STN, 2013.

Medida Provisória $n^{\circ}$ 1.984-22, de 27 de setembro de 2000. Acresce e altera dispositivos das Leis $\mathrm{n}^{\circ}$ 8.437, de 10 de setembro de 1997, 7.347, de 24 de julho de 1985, 8.429, de 2 de junho de 1992, 9.704, de 17 de novembro de 1998, do Decreto-Lei n167 5.452, de 1167 de maio de 1943, das Leis n167 5.869, de 11 de janeiro de 1973, e 4.348, de 26 de junho de 1964, e dá outras providências. Acesso: 25/01/2014. Disponível em: https://www.planalto.gov.br/ccivil_03/MPV/Antigas/1984-22.htm

Medida Provisória no 2.180-35, de 24 de agosto de 2001. Acresce e altera dispositivos das Leis nos 8.437, de 30 de junho de 1992, 9.028, de 12 de abril de 1995, 9.494, de 10 de setembro de 1997, 7.347, de 24 de julho de 1985, 8.429, de 2 de junho de 1992, 9.704, de 17 de novembro de 1998, do Decreto-Lei no 5.452, de 1o de maio de 1943, das Leis nos 5.869, de 11 de janeiro de 1973, e 4.348, de 26 de junho de 1964, e dá outras providências. Acesso 25/01/2014. Disponível em: http://www.planalto.gov.br/ccivil_03/MPV/2180-35.htm\#art3.

Decreto $\mathrm{n}^{\mathrm{o}}$ 7.392, de 13 de dezembro de 2010. Aprova a Estrutura Regimental e o

Quadro Demonstrativo dos Cargos em Comissão da Advocacia-Geral da União, aprova o Quadro Demonstrativo dos Cargos em Comissão da Procuradoria-Geral Federal e remaneja cargos em comissão para a Advocacia-Geral da União e para a Procuradoria-Geral Federal. Acesso 25/01/2014. Disponível em: http://www.planalto.gov.br/ccivil_03/_Ato20072010/2010/Decreto/D7392.htm

BRUNET, E. Measuring the costs of civil justice. Michigan Law Review. University of Michigan, Michigan, vol. 83, n. 4, p. 916-938, fev/mar. 1985.

CHING, H. Y.; SILVEIRA, H. F. R.; FREIRE, F. S. Gestão de custos na administração pública: estudo de casos do governo da Bahia e do Banco Central do Brasil. Revista de Economia e Administração, v. 10, n. 2, p. 262-284, abr/jun. 2011.

COLAUTO, R. D.; BEUREN, I. M. O custeio baseado em atividade para apuração dos custos de uma organização hospitalar filantrópica. Revista UnB Contábil. UnB, Brasília, v. 6, n. 2, p. 9-36, jul/dez. 2003. 
COllatto, D. C.; REGinATO, L. Método de Custeio Variável, Custeio Direto e Teoria das Restrições no contexto da Gestão Estratégica de Custos: Um Estudo Aplicado ao Instituto de Idiomas Unilínguas. CONGRESSO INTERNACIONAL DE CUSTOS, IX, 2005, Florianópolis.

DEPARTAMENTO DE CÁLCULOS E PERÍCIAS (DCP) da Advocacia-Geral da União. Mapa estratégico 2012-2015. Brasília, 2012.

FERNANDES, J. C. C.; SLOMSKI, V. A gestão de custos no contexto da qualidade no serviço público: um estudo entre organizações Brasileiras. CONGRESSO USP DE INICIAÇÃO CIENTÍFICA EM CONTABILIDADE, VIII, 2011, São Paulo.

GARRISON, R. H.; NOREEN, E. W.; BREWER, P. C. Contabilidade Gerencial. 14. Ed. Porto Alegre: AMGH, 2013.

INSTITUTO DE PESQUISA ECONOMICA APLICADA (IPEA) (Brasil). Custo Unitário do Processo de Execução Fiscal da Justiça Federal. Relatório de Pesquisa. Brasília, 2011. 43 p.[a]

Custo Unitário do Processo de Execução Fiscal da Justiça Federal. Comunicado do IPEA no 83. Brasília, 2011. 12 p.[b]

Custo e Tempo do Processo de Execução Fiscal Promovido pela Procuradoria Geral da Fazenda Nacional. Nota Técnica. Brasília, 2011. 17 p. [c]

HAIR Jr., J. F.; BLACK, W. C.; BABIN, B. J.; ANDERSON, R. E.; TATHAM, R. L. Análise Multivariada de Dados. 6. Ed. Porto Alegre: Bookman, 2009.

HOLANDA, V. B.; WELTMAN, F. L.; GUIMARÃES, F. Sistema de informações de custos na administração pública federal: uma política de Estado. 1. Ed. FGV, 2010. 160p.

KAKALIK, J. S.; ROSS, R. L. Costs of the civil Justice System: Court expenditures for various types of civil cases. 1. Ed. Rand Corporation, 1983. 164p.

KAPlAN, R. S.; ANDERSON, S. R. Time-Driven Activity-Based Costing. Harvard Business Review, Boston, v. 82. p. 131-138. nov. 2004.

LOPES, M. M.; BRANCO, V. T. F. C.; SOARES; J. B. Utilização dos testes estatísticos de Komolgorov-Smirnov e Shapiro-Wilk para a verificação da normalidade para materiais de pavimentação. Revista Transportes. USP, São Carlos, v. 21. n. 1, p. 59-66, jan/abr. 2013.

MACHADO, N.; HOLANDA, V. B.; Diretrizes e modelo conceitual de custos para o setor público a partir da experiência no Governo Federal do Brasil. Revista de Administração Pública. FGV, Rio de Janeiro, v. 44, n. 4, p. 791-820, jul/ago. 2010.

MACHADO, N.; Sistema de informações de custos: diretrizes para a integração ao orçamento público e à contabilidade governamental. 2002. $233 \mathrm{f}$. Tese (Doutorado em Controladoria e Contabilidade) - Departamento de Contabilidade e Atuária, Universidade de São Paulo, São Paulo, 2002.

MACHADO, M. R. R. Custo de Oportunidade em Processos Judiciais Eletrônicos para a Parte Autora: Um estudo de caso na Procuradoria da União em Goiás. 2011. 91 f. 
Dissertação (Mestrado em Ciências Contábeis) - Programa Multiinstitucional e Inter-Regional de Pós-Graduação em Ciências Contábeis, Brasília, 2011.

MAGAlHÃES, E. A.; SILVEIRA, S. F. R.; ABRANTES, L. A.; FERREIRA, M. A. M.; WAKIM, V. R. Custo do ensino de graduação em instituições federais de ensino superior: o caso da Universidade Federal de Viçosa. Revista de Administração Pública - RAP. FGV, Rio de Janeiro, v. 44, n. 3, p. 637-666, maio/jun. 2010.

MAHER, M. Contabilidade de Custos: criando valor para a administração. 1. Ed. São Paulo: Atlas, 2001.

MARTINS, L. Diretrizes para a elaboração de indicadores de custos no Governo Federal. Secretária do Tesouro Nacional. Brasília, 2011. 80p.

MARTINS, E. Contabilidade de Custos. 9. Ed. São Paulo: Atlas, 2003.

MORGAN, B. F. A determinação do custo de ensino na educação superior: o caso da Universidade de Brasília. 2004. 159 f. Dissertação (Mestrado em Contabilidade) - Programa Multiinstitucional e Inter-Regional de Pós-Graduação em Ciências Contábeis, Universidade de Brasília, Brasília, 2004.

MORGAN, B. F.; ROSA, M. S. Custos em empresas prestadoras de serviços: o conceito de objeto de custo e a realidade das empresas. Revista Contabilidade Vista e Revista. UFMG, Belo Horizonte, v. 17, n. 4, p. 97-111, out/dez. 2006.

PERNOT, E.; ROODHOOFT, F.; ABBEELE, A. V. D. Time-Driven Activity-Based Costing for Inter-Library Services: A Case Study in University. The Journal of Academic Libraruanship, v. 33, n. 5, p. 551-560, sep. 2007.

PETER, M. G. A.; MARTINS, E.; PESSOA, M. N. M.; PETER, F. A. Proposta de um sistema de custos para as Universidades Federais Brasileiras fundamentado no Activity Based Costing. Encontro da Associação Nacional de Pós-Graduação e Pesquisa em Administração, XXVII, 2003, Atibaia.

REMÍGIO, H. G. Custos no serviço público - um modelo aplicado ao custeio dos processos judiciais. 2002. 167 f. Dissertação (Mestrado em Contabilidade) - Programa Multiinstitucional e Inter-Regional de Pós-Graduação em Ciências Contábeis, Universidade de Brasília, Brasília, 2002.

REZENDE, F.; CUNHA, A.; BEVILACQUA, R. Informações de custos e qualidade do gasto público: lições da experiência internacional. Revista de Administração Pública - RAP. FGV, Rio de Janeiro, v. 44, n. 4, p. 959-952, jul/ago. 2010.

ROCHA, W. Custo de mão-de-obra e encargos sociais. Cadernos de Estudos $n^{\circ} 6$, FIPECAFI, São Paulo. out. 1992.

SALVATORE, D.; REAGLE, D. Statistics and Econometrics - Schaum's Outline Series. 2. Ed. New York; McGraw Hill, 2011. 
SANTOS, W. V. Sistema de informação de custos do Governo Federal: Modelo conceitual, solução tecnológica e gestão do sistema. CONGRESSO CONSAD DE GESTÃO PÚBLICA, IV, 2011, Brasília.

SANTOS, B. S.; GOMES, C.; ALMEIDA, J.; TRINCÃO, C; SOUSA, F.; BRANCO, P.; FERNANDO, P.; BAPTISTA, S.; ALVES, M. J.; MENDES, J. M.; BARRETO, I.; Os actos e os tempos dos juízes: contributos para a construção de indicadores da distribuição processual nos juízos cíveis. Observatório Permanente da Justiça Portuguesa: Centro de Estudos Sociais. Universidade de Coimbra, Coimbra, 2005.

SCHWENGBER, S. B. Qualidade na Provisão de Serviços Judiciais: estimativa dos ganhos de eficiência e do "gargalo" reduzível na Justiça de $1^{\circ}$ Grau. 2007. Monografia (Monografia premiada com o primeiro lugar no XII Prêmio Tesouro Nacional) ESAF, Brasília: 2007. 77p.

SHAPIRO, S. S.; WILK, M. B. Na Analysis of Variance Test for Normality (Complete Samples). Biometrika Trust. Grã-Bretanha, v. 52, n. 3/4, p. 591-611, dec. 1965.

SIC - Sistema de Informações de Custos do Governo Federal. Secretária do Tesouro Nacional - Ministério da Fazenda. Brasília. Acesso em: 01 outubro 2014.

SILVA, B. F.; ROCHA, E. S. Uma contribuição para a implantação de custos no setor público: estudo de caso - Embrapa e Bacen. CONGRESSO BRASILEIRO DE CUSTOS, XVI, 2009, Fortaleza.

SILVA, C. A. T.; MARINHO, D. N. C.; WALTER, M. I. M. T.; SOUZA, L. M. Estudo de Custos do Sistema Nacional de Emprego - SINE. Ministério do Trabalho e Emprego e Universidade de Brasília. 2011.

SÖTHE, A.; DILL, P. R.; GUBIANI, C. A.; SILVA, M. Custos no setor público: análise da inserção do método ABC após a publicação da LRF e do estudo $n^{0} 12$ do IFAC. Revista Estudo \& Debate, Lajeado, v. 21, n. 1, p. 158-178, 2014.

STEVENSON, W. J. Estatística Aplicada a Administração. 1. Ed. São Paulo: Harper \& Row do Brasil, 1981.

TRIOLA, M. F. Introdução à Estatística. 7. Ed. Rio de Janeiro: LTC, 1999.

WALLIMAN, N. Your Research Project. 2. Ed. Londres: SAGE, 2005.

ZANIEVICZ, M.; BEUREN, I. M.; SANTOS, P. S. A.; KLOEPPEL, N. R. Métodos de Custeio: uma meta-análise dos artigos apresentados no Congresso Brasileiro de Custos no período de 1994 a 2010. Revista Brasileira de Gestão de Negócios, São Paulo, v. 15, n. 49, p. 601-616, out/dez. 2013.

ZIMMERMAN, J. L. Accouting for Decision Making and Control. 7. Ed. McGraw-Hill Irwin, 2010. Disponível em: https://www.academia.edu/6382560/Accounting_for_Decision_ Making_and_Control_7th_Edition. 
APÊNDICE A - Quantidade mensal de pareceres técnicos emitidos por tipo de parecer de janeiro de 2011 a julho de 2014

\begin{tabular}{|c|c|c|c|c|c|c|c|c|c|c|}
\hline \multirow[t]{2}{*}{ Data } & \multicolumn{2}{|c|}{ Conclusivos } & \multirow{2}{*}{$\underset{1}{\text { Despacho }}$} & \multicolumn{2}{|c|}{ Devolutivos } & \multicolumn{2}{|c|}{ Informativos } & \multicolumn{2}{|c|}{ Parcelamento } & \multirow[t]{2}{*}{ Total } \\
\hline & $\mathbf{A}$ & B & & $\mathbf{A}$ & B & $\mathbf{A}$ & B & $\mathbf{A}$ & B & \\
\hline jan/11 & 501 & 9 & 0 & 48 & 1 & 309 & 56 & $\overline{0}$ & 0 & 924 \\
\hline fev/11 & 765 & 16 & 0 & 45 & 4 & 160 & 81 & 1 & 0 & 1072 \\
\hline $\operatorname{mar} / 11$ & 1119 & 12 & 0 & 68 & 2 & 262 & 102 & 2 & 3 & 1570 \\
\hline $\mathrm{abr} / 11$ & 854 & 3 & 0 & 53 & 4 & 180 & 53 & 0 & 0 & 1147 \\
\hline mai/11 & 1191 & 20 & 1 & 72 & 1 & 233 & 68 & 2 & 1 & 1589 \\
\hline jun/11 & 1163 & 8 & 0 & 109 & 8 & 437 & 81 & 2 & 0 & 1808 \\
\hline jul/11 & 928 & 12 & 0 & 107 & 0 & 304 & 77 & 1 & 5 & 1434 \\
\hline ago/11 & 1222 & 14 & 0 & 57 & 0 & 231 & 49 & 3 & 0 & 1576 \\
\hline set/11 & 979 & 11 & 0 & 86 & 2 & 336 & 41 & 2 & 0 & 1457 \\
\hline out/11 & 963 & 13 & 0 & 73 & 0 & 201 & 50 & 5 & 3 & 1308 \\
\hline nov/11 & 642 & 14 & 0 & 92 & 1 & 177 & 26 & 0 & 1 & 953 \\
\hline dez/11 & 614 & 12 & 0 & 39 & 1 & 243 & 53 & 2 & 0 & 964 \\
\hline jan/12 & 446 & 15 & 0 & 30 & 0 & 122 & 26 & 4 & 2 & 645 \\
\hline fev/12 & 526 & 10 & 0 & 46 & 0 & 102 & 17 & 0 & 0 & 701 \\
\hline $\mathrm{mar} / 12$ & 1027 & 16 & 0 & 74 & 0 & 148 & 52 & 2 & 0 & 1319 \\
\hline $\mathrm{abr} / 12$ & 904 & 14 & 1 & 53 & 0 & 163 & 51 & 6 & 0 & 1192 \\
\hline mai/12 & 1147 & 20 & 0 & 59 & 2 & 270 & 99 & 0 & 0 & 1597 \\
\hline jun/12 & 1010 & 13 & 0 & 71 & 0 & 197 & 80 & 0 & 0 & 1371 \\
\hline $\mathrm{jul} / 12$ & 1117 & 19 & 0 & 63 & 0 & 175 & 51 & 1 & 0 & 1426 \\
\hline ago/12 & 1060 & 20 & 0 & 68 & 0 & 203 & 17 & 1 & 0 & 1369 \\
\hline set/12 & 688 & 34 & 0 & 34 & 4 & 184 & 8 & 4 & 1 & 957 \\
\hline out/12 & 1026 & 48 & 0 & 43 & 2 & 146 & 14 & 4 & 4 & 1287 \\
\hline nov/12 & 838 & 80 & 1 & 27 & 6 & 124 & 22 & 0 & 4 & 1102 \\
\hline dez/12 & 739 & 31 & 0 & 22 & 2 & 145 & 1 & 0 & 2 & 942 \\
\hline jan/13 & 446 & 137 & 0 & 25 & 14 & 79 & 43 & 0 & 2 & 746 \\
\hline fev/13 & 554 & 212 & 0 & 24 & 9 & 72 & 25 & 1 & 7 & 904 \\
\hline mar/13 & 821 & 121 & 0 & 33 & 5 & 89 & 32 & 5 & 0 & 1106 \\
\hline $\mathrm{abr} / 13$ & 954 & 196 & 0 & 47 & 7 & 100 & 36 & 0 & 4 & 1344 \\
\hline mai/13 & 762 & 143 & 0 & 56 & 6 & 136 & 35 & 0 & 0 & 1138 \\
\hline jun/13 & 565 & 84 & 0 & 58 & 7 & 143 & 47 & 0 & 0 & 904 \\
\hline $\mathrm{jul} / 13$ & 677 & 89 & 1 & 63 & 9 & 150 & 37 & 0 & 3 & 1029 \\
\hline ago/13 & 844 & 173 & 0 & 26 & 7 & 77 & 31 & 2 & 3 & 1163 \\
\hline set/13 & 858 & 139 & 0 & 76 & 18 & 117 & 39 & 1 & 1 & 1249 \\
\hline out/13 & 860 & 102 & 0 & 69 & 11 & 86 & 26 & 1 & 0 & 1155 \\
\hline nov/13 & 1144 & 69 & 0 & 82 & 6 & 92 & 17 & 2 & 2 & 1414 \\
\hline dez/13 & 657 & 53 & 0 & 59 & 3 & 70 & 18 & 0 & 3 & 863 \\
\hline $\mathrm{jan} / 14$ & 548 & 56 & 4 & 40 & 5 & 41 & 14 & 1 & 0 & 709 \\
\hline fev/14 & 849 & 86 & 0 & 59 & 5 & 133 & 20 & 1 & 3 & 1156 \\
\hline mar/14 & 881 & 90 & 0 & 39 & 9 & 62 & 24 & 1 & 2 & 1108 \\
\hline $\mathrm{abr} / 14$ & 619 & 79 & 1 & 48 & 5 & 88 & 21 & 0 & 6 & 867 \\
\hline mai/14 & 721 & 85 & 1 & 63 & 5 & 95 & 19 & 0 & 6 & 995 \\
\hline jun/14 & 669 & 77 & 0 & 56 & 5 & 92 & 17 & 0 & 1 & 917 \\
\hline
\end{tabular}


Continuação...

\begin{tabular}{|c|c|c|c|c|c|c|c|c|c|c|}
\hline \multirow[t]{2}{*}{ Data } & \multicolumn{2}{|c|}{ Conclusivos } & \multirow{2}{*}{$\begin{array}{c}\text { Despacho } \\
1\end{array}$} & \multicolumn{2}{|c|}{ Devolutivos } & \multicolumn{2}{|c|}{ Informativos } & \multicolumn{2}{|c|}{ Parcelamento } & \multirow{2}{*}{ Total } \\
\hline & $\overline{\mathbf{A}}$ & $\overline{\mathbf{B}}$ & & $\overline{\mathbf{A}}$ & $\overline{\mathbf{B}}$ & $\overline{\mathbf{A}}$ & $\overline{\mathbf{B}}$ & $\overline{\mathbf{A}}$ & B & \\
\hline$\overline{\mathrm{jul} / 14}$ & 717 & 72 & 0 & 91 & 2 & 69 & 19 & 0 & 4 & 974 \\
\hline Total & 35615 & 2527 & 10 & 2453 & 178 & 6843 & 1695 & 57 & 73 & 49451 \\
\hline
\end{tabular}

Fonte: Elaborado pelo autor com dados do Atuação (2014).

A- Pareceres com todas as variáveis.

B- Pareceres com falta das variáveis 13 e 14 da Tabela 1.

1- Não houve registro com falta de variáveis. 
APÊNDICE B - Valor dos materiais diretos e mão-de-obra direta no período de janeiro de 2011 a julho de 2014.

\begin{tabular}{|c|c|c|c|c|c|}
\hline Referência & $\begin{array}{l}\text { Material de } \\
\text { escritório }\end{array}$ & $\begin{array}{l}\text { Cartucho P/ } \\
\text { Impressora }\end{array}$ & Papel & Remuneração & $\begin{array}{l}\text { Total Custos } \\
\text { Diretos }\end{array}$ \\
\hline $\mathrm{jan} / 2011$ & - & - & - & $482.162,81$ & $482.162,81$ \\
\hline fev/2011 & $1.430,40$ & $4.236,75$ & $2.117,60$ & $505.157,89$ & $512.942,64$ \\
\hline mar/2011 & $1.053,48$ & $4.322,60$ & $1.966,03$ & $505.881,74$ & $513.223,85$ \\
\hline $\mathrm{abr} / 2011$ & 503,64 & $3.273,43$ & 786,41 & $507.324,84$ & $511.888,32$ \\
\hline mai/2011 & $1.576,61$ & $3.361,22$ & $1.572,83$ & $497.782,67$ & $504.293,33$ \\
\hline jun/2011 & $1.034,58$ & $4.991,35$ & $2.208,14$ & $491.264,77$ & $499.498,84$ \\
\hline $\mathrm{jul} / 2011$ & 773,94 & $5.601,00$ & $1.059,91$ & $504.797,47$ & $512.232,32$ \\
\hline ago/2011 & 468,71 & $1.363,00$ & 493,53 & $498.069,33$ & $500.394,57$ \\
\hline set/2011 & 634,22 & $1.648,00$ & 493,53 & $499.927,22$ & $502.702,97$ \\
\hline out/2011 & 535,68 & 824,00 & 575,79 & $510.293,83$ & $512.229,30$ \\
\hline nov/2011 & $1.133,59$ & $1.648,00$ & $1.084,88$ & $522.983,15$ & $526.849,62$ \\
\hline $\mathrm{dez} / 2011$ & 736,03 & $1.648,00$ & $1.446,52$ & $528.512,10$ & $532.342,65$ \\
\hline $\mathrm{jan} / 2012$ & 57,91 & $1.677,00$ & - & $531.083,40$ & $532.818,31$ \\
\hline fev/2012 & 630,20 & $2.299,18$ & $1.205,44$ & $533.502,48$ & $537.637,30$ \\
\hline mar/2012 & 235,76 & $2.299,18$ & 794,18 & $506.606,12$ & $509.935,24$ \\
\hline abr/2012 & $1.533,00$ & $2.299,19$ & 953,02 & $500.925,94$ & $505.711,15$ \\
\hline $\mathrm{mai} / 2012$ & 517,35 & $2.299,19$ & $1.551,09$ & $503.788,83$ & $508.156,46$ \\
\hline jun/2012 & 331,53 & $2.105,00$ & $1.121,38$ & $505.910,29$ & $509.468,20$ \\
\hline jul/2012 & 593,24 & 446,20 & 747,59 & $533.619,85$ & $535.406,88$ \\
\hline ago/2012 & 287,07 & $1.068,52$ & 741,33 & $536.435,72$ & $538.532,64$ \\
\hline set/2012 & 507,32 & 653,00 & 741,33 & $521.426,25$ & $523.327,90$ \\
\hline out/2012 & 798,14 & 639,72 & 889,59 & $532.318,34$ & $534.645,79$ \\
\hline nov/2012 & 140,85 & $1.677,00$ & 889,60 & $542.873,69$ & $545.581,14$ \\
\hline $\mathrm{dez} / 2012$ & 187,35 & 253,18 & 741,33 & $549.281,24$ & $550.463,10$ \\
\hline $\mathrm{jan} / 2013$ & 233,92 & 319,86 & 515,89 & $534.712,81$ & $535.782,48$ \\
\hline fev/2013 & 92,12 & - & 442,19 & $505.354,70$ & $505.889,01$ \\
\hline $\mathrm{mar} / 2013$ & 195,88 & $3.175,00$ & 442,19 & $518.693,58$ & $522.506,65$ \\
\hline $\mathrm{abr} / 2013$ & 273,24 & 999,76 & 589,60 & $511.312,87$ & $513.175,47$ \\
\hline $\mathrm{mai} / 2013$ & 863,00 & $1.138,00$ & 737,00 & $510.303,52$ & $513.041,52$ \\
\hline jun/2013 & 197,40 & $1.799,02$ & 737,00 & $515.624,73$ & $518.358,15$ \\
\hline $\mathrm{jul} / 2013$ & 150,15 & - & 737,00 & $528.835,83$ & $529.722,98$ \\
\hline ago/2013 & 450,15 & - & 737,00 & $524.610,00$ & $525.797,15$ \\
\hline set/2013 & 338,59 & - & 736,31 & $518.232,22$ & $519.307,12$ \\
\hline out/2013 & 62,04 & - & 736,32 & $529.133,62$ & $529.931,98$ \\
\hline nov/2013 & 137,70 & - & 849,89 & $525.437,63$ & $526.425,22$ \\
\hline $\operatorname{dez} / 2013$ & 646,80 & - & 242,83 & $549.077,22$ & $549.966,85$ \\
\hline $\mathrm{jan} / 2014$ & 27,81 & - & 728,49 & $544.206,44$ & $544.962,74$ \\
\hline fev/2014 & - & 237,92 & - & $526.951,64$ & $527.189,56$ \\
\hline $\mathrm{mar} / 2014$ & 62,87 & - & 648,00 & $523.209,60$ & $523.920,47$ \\
\hline $\mathrm{abr} / 2014$ & 182,07 & - & 648,00 & $524.864,60$ & $525.694,67$ \\
\hline mai/2014 & 248,35 & - & 972,00 & $516.894,78$ & $518.115,13$ \\
\hline jun/2014 & 85,32 & - & 729,00 & $510.758,03$ & $511.572,35$ \\
\hline jul/2014 & 45,25 & - & 729,00 & $494.953,65$ & $495.727,90$ \\
\hline
\end{tabular}




\section{APÊNDICE C - Agrupamento dos Objetos da Ação cadastrados no Atuação}

\begin{tabular}{|c|c|}
\hline Objetos da Ação Cadastrados no Banco de Dados Atuação & Objetos da Ação Agrupados \\
\hline Acórdão TCU & \multirow[b]{2}{*}{ Acórdão TCU e Administrativos } \\
\hline Atos Administrativos/Multas & \\
\hline Adicional por Tempo de Serviço (Anuênio / Quinquênio) & $\begin{array}{l}\text { Adicional por Tempo de Serviço } \\
\text { (Anuênio/Quinquênio) }\end{array}$ \\
\hline Auxílio Alimentação & Auxílio Alimentação \\
\hline Contribuição Social (Inativo) & Contribuição Social (Inativo) \\
\hline Danos Morais e Materiais & \multirow[b]{2}{*}{ Danos Morais e Materiais } \\
\hline Perdas e Danos Morais/Materiais & \\
\hline Desapropriação Direta & \multirow{3}{*}{$\begin{array}{l}\text { Desapropriação Direta e Indireta e } \\
\text { Reint. De Posse }\end{array}$} \\
\hline Desapropriação Indireta & \\
\hline Reintegração de Posse & \\
\hline Diferenças Salariais & \multirow{11}{*}{$\begin{array}{l}\text { Diferenças Salariais (Equiparação, } \\
\text { Reenquadramento, Reintegração) }\end{array}$} \\
\hline Equiparação salarial & \\
\hline Reenquadramento & \\
\hline Férias & \\
\hline Isonomia entre Carreiras & \\
\hline Plano de Class. de Cargos e Salários-PCCS & \\
\hline Reintegração & \\
\hline Horas extras & \\
\hline Reclassificação de Cargos & \\
\hline Adicionais Diversos & \\
\hline Indenização de Campo - FUNASA & \\
\hline Diferenças Verbas SUS & Diferenças Verbas SUS \\
\hline FUNDEF & FUNDEF \\
\hline GDAFAZ - Gratificação de Desempenho de Atividade Fazendária & \multirow{13}{*}{$\begin{array}{l}\text { Gratificações de Desempenho - } \\
\text { Diversas }\end{array}$} \\
\hline GDAFAZ/GDPGTAS & \\
\hline GDARA - Gratificação de Desempenho de Reforma Agrária & \\
\hline GDASS - Gratificação de Desemp. de Atividade do Seguro Social & \\
\hline GDASST - Gratificação de Atividade de Seguridade Social e do Trabalho & \\
\hline GDASST/GDPST & \\
\hline GDATA - Gratificação de Desemp. de Atividade Técnico-Administrativa & \\
\hline GDATA/GDPGTAS & \\
\hline GDATFA - Grat. de Desemp. de Atividade Técnica de Fiscalização Agropecuária & \\
\hline $\begin{array}{l}\text { GDPGPE - Grat. de Desemp. do Plano Geral de Cargos e Salários do Poder } \\
\text { Executivo }\end{array}$ & \\
\hline GDPGTAS - Grat. de Desemp. de Atividade Técnico-Administrativa e de Suporte & \\
\hline GDPST - Grat. de Desemp. da Carteira da Previdência, Saúde e do Trabalho & \\
\hline Gratificações de Desempenho - Diversas & \\
\hline Honorários Advocatícios (União - Autora) & $\begin{array}{l}\text { Honorários Advocatícios (União - } \\
\text { Autora) }\end{array}$ \\
\hline Incorporação de quintos/décimos & \multirow{2}{*}{ Quintos/décimos/VPNI } \\
\hline Quintos/décimos/VPNI & \\
\hline
\end{tabular}


Continuação...

\begin{tabular}{|c|c|}
\hline Objetos da Ação Cadastrados no Banco de Dados Atuação & Objetos da Ação Agrupados \\
\hline Indenizações & \multirow{4}{*}{ Indenizações } \\
\hline Licença prêmio & \\
\hline Restituição de Valores & \\
\hline Rescisão de Contrato & \\
\hline Outros - A especificar & \multirow{5}{*}{ Outros - A especificar } \\
\hline Medicamentos & \\
\hline Programa de Demissão Voluntária - PDV & \\
\hline Taxa de Ocupação - Terrenos de Marinha & \\
\hline Companhias Aéreas & \\
\hline Parcelamento de Débito Art. 2 da Lei № 9.469/97 & \multirow{3}{*}{ Parcelamento } \\
\hline Parcelamento de Débito Art. 38 da Lei $\mathrm{N}^{\circ} 8.212 / 91$ & \\
\hline Parcelamento de Débito Art. 7 da Dec. № 2.346/97 & \\
\hline Perícia - Atraso de Pagto Faturas / Contratos & \multirow{14}{*}{ Perícia } \\
\hline Perícia - Ambiental & \\
\hline Perícia - Atuarial & \\
\hline Perícia - Engenharia & \\
\hline Perícia - FUNDEF & \\
\hline Perícia - Médica & \\
\hline Perícia - Setor Sucroalcooleiro & \\
\hline Perícia - Sistema Financeiro de Habitação & \\
\hline Perícia - SUS & \\
\hline Perícia - Trabalhista & \\
\hline Perícia Contábil & \\
\hline Perícia Criminal & \\
\hline Perícia Econômica/Financeira & \\
\hline Perícia Imobiliária & \\
\hline Reajuste - Plano Bresser - IPC/87 - 26,06\% & \multirow{3}{*}{ Planos Bresser, Collor e Verão } \\
\hline Reajuste - Plano Collor - IPC/90 - 84,32\% & \\
\hline Reajuste - Plano Verão - URP - 26,05\% & \\
\hline Reajuste Salarial 28,86\% (Servidor Civil) & \multirow{2}{*}{$\begin{array}{l}\text { Reajuste Salarial 28,86\% (Civil e } \\
\text { Militar) }\end{array}$} \\
\hline Reajuste Salarial 28,86\% (militares) & \\
\hline Reajuste - URP Abril/Maio/88 - 16,19\% & $\begin{array}{l}\text { Reajuste - URP Abril/Maio/88 - } \\
16,19 \%\end{array}$ \\
\hline Reajuste Conversão URV - 10,94\% / 11,98\% & $\begin{array}{l}\text { Reajuste Conversão URV - 10,94\% / } \\
11,98 \%\end{array}$ \\
\hline Resíduo dos 3,17\% (lei 8.880/94) & Resíduo dos 3,17\% (lei 8.880/94) \\
\hline Revisão de Aposentadoria & \multirow{3}{*}{ Revisão de Aposentadoria e Pensões } \\
\hline Revisão de Pensão & \\
\hline Revisão de Pensões & \\
\hline TDA - Títulos da Dívida Agrária & TDA - Títulos da Dívida Agrária \\
\hline União - Subsidiária & União - Subsidiária \\
\hline
\end{tabular}




\section{APÊNDICE D - Agrupamento dos Tipos de Cálculo cadastrados no Atuação}

\begin{tabular}{|c|c|}
\hline Tipos de Cálculo Cadastrados no Banco de Dados Atuação & Tipo de Cálculo Agrupados \\
\hline Acordo e transações & Acordo e transações \\
\hline Apuração PSS & Apuração PSS \\
\hline Atualização de Conta & Atualização de Conta \\
\hline Conferência de Conta & \multirow{2}{*}{ Conferencia e Manifestação técnica } \\
\hline Manifestação técnica & \\
\hline Embargo (Art. 730 - CPC) & Embargo (Art. 730 - CPC) \\
\hline Honorários advocatícios & \multirow{2}{*}{ Honorários Advocatícios e Periciáis } \\
\hline Honorários periciais & \\
\hline Impugnação de Valores & \multirow{2}{*}{ Impugnação de Valores } \\
\hline Impugnação de Valores da causa & \\
\hline Indicação de Assistente & \multirow{4}{*}{ Cálculos Períciais } \\
\hline Laudo pericial & \\
\hline Elaboração de Quesitos & \\
\hline Outros procedimentos perícia & \\
\hline Liquidação de sentença & \multirow{3}{*}{ Liquidação de sentença } \\
\hline Diligência & \\
\hline Artigo de liquidação & \\
\hline Pedido totalmente improcedente $1^{\circ}$ grau & \multirow{2}{*}{ Pedidos Totalmente Improcedentes } \\
\hline Pedido totalmente improcedente tribunal & \\
\hline Precatórios & Precatórios \\
\hline Propositura de ação & \multirow{6}{*}{ Propositura de Ação - Auto Execução } \\
\hline Propositura de ação Rescisória & \\
\hline Proposta de Acordo - Portaria 1052 e 1053/06 & \\
\hline Tomada de conta (TCU) & \\
\hline Auto Execução & \\
\hline Parcelamento de débito & \\
\hline
\end{tabular}


APÊNDICE E - Custo unitário corrente do parecer técnico pelo método direto e com acréscimo dos custos indiretos rateados em função do metro quadrado.

\begin{tabular}{|c|c|c|c|c|c|c|c|}
\hline Referência & $\begin{array}{l}\text { Total dos } \\
\text { Custos } \\
\text { Diretos }\end{array}$ & $\begin{array}{l}\text { Custo com } \\
\text { Aluguel* }\end{array}$ & $\begin{array}{c}\text { Demais } \\
\text { Custos } \\
\text { Indiretos* }\end{array}$ & $\begin{array}{c}\text { Total de } \\
\text { Pareceres } \\
\text { Emitidos }\end{array}$ & $\begin{array}{c}\text { Custo } \\
\text { Unitário } \\
\text { Met. Direto }\end{array}$ & $\begin{array}{c}\text { Custo } \\
\text { Unitário } \\
\text { Direto e } \\
\text { Indireto }\end{array}$ & $\begin{array}{c}\text { Acréscimo dos } \\
\text { Custos } \\
\text { Indiretos }\end{array}$ \\
\hline $\mathrm{jan} / 2011$ & $482.162,81$ & $54.683,05$ & - & 924 & 521,82 & 581,00 & $11,34 \%$ \\
\hline $\mathrm{fev} / 2011$ & $512.942,64$ & $54.683,05$ & - & 1072 & 478,49 & 529,50 & $10,66 \%$ \\
\hline $\operatorname{mar} / 2011$ & $513.223,85$ & $54.683,05$ & - & 1570 & 326,89 & 361,72 & $10,65 \%$ \\
\hline $\mathrm{abr} / 2011$ & $511.888,32$ & $54.683,05$ & - & 1147 & 446,28 & 493,96 & $10,68 \%$ \\
\hline mai/2011 & $504.293,33$ & $54.683,05$ & - & 1589 & 317,37 & 351,78 & $10,84 \%$ \\
\hline jun/2011 & $499.498,84$ & $54.683,05$ & - & 1808 & 276,27 & 306,52 & $10,95 \%$ \\
\hline jul/2011 & $512.232,32$ & $54.683,05$ & - & 1434 & 357,21 & 395,34 & $10,68 \%$ \\
\hline ago/2011 & $500.394,57$ & $54.683,05$ & - & 1576 & 317,51 & 352,21 & $10,93 \%$ \\
\hline set/2011 & $502.702,97$ & $54.683,05$ & - & 1457 & 345,03 & 382,56 & $10,88 \%$ \\
\hline out/2011 & $512.229,30$ & $54.683,05$ & - & 1308 & 391,61 & 433,42 & $10,68 \%$ \\
\hline nov/2011 & $526.849,62$ & $56.548,62$ & - & 953 & 552,83 & 612,17 & $10,73 \%$ \\
\hline dez/2011 & $532.342,65$ & $58.680,70$ & - & 964 & 552,22 & 613,09 & $11,02 \%$ \\
\hline $\mathrm{jan} / 2012$ & $532.818,31$ & $58.680,70$ & - & 645 & 826,07 & 917,05 & $11,01 \%$ \\
\hline fev/2012 & $537.637,30$ & $58.680,70$ & - & 701 & 766,96 & 850,67 & $10,91 \%$ \\
\hline $\operatorname{mar} / 2012$ & $509.935,24$ & $58.680,70$ & - & 1319 & 386,61 & 431,10 & $11,51 \%$ \\
\hline $\mathrm{abr} / 2012$ & $505.711,15$ & $58.680,70$ & - & 1192 & 424,25 & 473,48 & $11,60 \%$ \\
\hline mai/2012 & $508.156,46$ & $58.680,70$ & - & 1597 & 318,19 & 354,94 & $11,55 \%$ \\
\hline jun/2012 & $509.468,20$ & $58.680,70$ & - & 1371 & 371,60 & 414,40 & $11,52 \%$ \\
\hline jul/2012 & $535.406,88$ & $58.680,70$ & - & 1426 & 375,46 & 416,61 & $10,96 \%$ \\
\hline ago/2012 & $538.532,64$ & $58.680,70$ & - & 1369 & 393,38 & 436,24 & $10,90 \%$ \\
\hline set/2012 & $523.327,90$ & $58.680,70$ & - & 957 & 546,84 & 608,16 & $11,21 \%$ \\
\hline out/2012 & $534.645,79$ & $58.680,70$ & - & 1287 & 415,42 & 461,02 & $10,98 \%$ \\
\hline nov/2012 & $545.581,14$ & $60.173,18$ & - & 1102 & 495,08 & 549,69 & $11,03 \%$ \\
\hline $\mathrm{dez} / 2012$ & $550.463,10$ & $61.878,87$ & - & 942 & 584,36 & 650,04 & $11,24 \%$ \\
\hline $\mathrm{jan} / 2013$ & $535.782,48$ & $61.878,87$ & - & 746 & 718,21 & 801,15 & $11,55 \%$ \\
\hline fev/2013 & $505.889,01$ & $61.878,87$ & - & 904 & 559,61 & 628,06 & $12,23 \%$ \\
\hline $\operatorname{mar} / 2013$ & $522.506,65$ & $61.878,87$ & - & 1106 & 472,43 & 528,38 & $11,84 \%$ \\
\hline $\mathrm{abr} / 2013$ & $513.175,47$ & $61.878,87$ & - & 1344 & 381,83 & 427,87 & $12,06 \%$ \\
\hline mai/2013 & $513.041,52$ & $61.878,87$ & - & 1138 & 450,83 & 505,20 & $12,06 \%$ \\
\hline jun/2013 & $518.358,15$ & $61.878,87$ & - & 904 & 573,41 & 641,86 & $11,94 \%$ \\
\hline $\mathrm{jul} / 2013$ & $529.722,98$ & $61.878,87$ & - & 1029 & 514,79 & 574,93 & $11,68 \%$ \\
\hline ago/2013 & $525.797,15$ & $61.878,87$ & - & 1163 & 452,10 & 505,31 & $11,77 \%$ \\
\hline set/2013 & $519.307,12$ & $61.878,87$ & - & 1249 & 415,78 & 465,32 & $11,92 \%$ \\
\hline out/2013 & $529.931,98$ & $61.878,87$ & - & 1155 & 458,82 & 512,39 & $11,68 \%$ \\
\hline nov/2013 & $526.425,22$ & $66.653,42$ & - & 1414 & 372,30 & 419,43 & $12,66 \%$ \\
\hline dez/2013 & $549.966,85$ & $72.110,04$ & - & 863 & 637,27 & 720,83 & $13,11 \%$ \\
\hline $\mathrm{jan} / 2014$ & $544.962,74$ & $72.110,04$ & $48.359,16$ & 709 & 768,64 & 938,55 & $22,11 \%$ \\
\hline fev/2014 & $527.189,56$ & $72.110,04$ & $29.724,67$ & 1156 & 456,05 & 544,14 & $19,32 \%$ \\
\hline $\operatorname{mar} / 2014$ & $523.920,47$ & $72.110,04$ & $25.608,76$ & 1108 & 472,85 & 561,05 & $18,65 \%$ \\
\hline
\end{tabular}


Continuação...

\begin{tabular}{|c|c|c|c|c|c|c|c|}
\hline Referência & $\begin{array}{c}\text { Total dos } \\
\text { Custos } \\
\text { Diretos }\end{array}$ & $\begin{array}{c}\text { Custo com } \\
\text { Aluguel* }\end{array}$ & $\begin{array}{c}\text { Demais Custos } \\
\text { Indiretos* }\end{array}$ & $\begin{array}{c}\text { Total de } \\
\text { Pareceres } \\
\text { Emitidos }\end{array}$ & $\begin{array}{c}\text { Custo } \\
\text { Unitário } \\
\text { Met. Direto }\end{array}$ & $\begin{array}{c}\text { Custo } \\
\text { Unitário } \\
\text { Direto e } \\
\text { Indireto }\end{array}$ & $\begin{array}{c}\text { Acréscimo dos } \\
\text { Custos } \\
\text { Indiretos }\end{array}$ \\
\hline abr/2014 & $525.694,67$ & $72.110,04$ & $53.891,38$ & 867 & 606,34 & 751,67 & $23,97 \%$ \\
\hline mai/2014 & $518.115,13$ & $72.110,04$ & $35.377,27$ & 995 & 520,72 & 628,75 & $20,75 \%$ \\
\hline jun/2014 & $511.572,35$ & $72.110,04$ & $35.755,11$ & 917 & 557,88 & 675,50 & $21,09 \%$ \\
\hline jul/2014 & $495.727,90$ & $72.110,04$ & $22.430,29$ & 974 & 508,96 & 606,02 & $19,07 \%$ \\
\hline
\end{tabular}

Fonte: Elaborado pelo autor, em valores correntes.

* O critério de rateio foi pela área ocupada pelo DCP. 
APÊNDICE F - Custos Indiretos do Edifício SEDE I da AGU.

\begin{tabular}{|c|c|c|c|c|c|c|c|}
\hline DESCRIÇÃO DO CUSTO & JAN/2014 & FEV/2014 & MAR/2014 & ABR/2014 & MAIO/2014 & JUN/2014 & JUL/2014 \\
\hline LOCACAO DE IMOVEIS & $\mathrm{R} \$ 1.800 .000,00$ & $\mathrm{R} \$ 1.800 .000,00$ & $\mathrm{R} \$ 1.800 .000,00$ & $\mathrm{R} \$ 1.800 .000,00$ & $\mathrm{R} \$ 1.800 .000,00$ & $\mathrm{R} \$ 1.800 .000,00$ & $\mathrm{R} \$ 1.800 .000,00$ \\
\hline ASSINATURAS DE PERIODICOS E ANUIDADES & $\mathrm{R} \$ 3.934,33$ & & $\mathrm{R} \$ 8.298,64$ & $\mathrm{R} \$ 4.149,32$ & $\mathrm{R} \$ 8.169,32$ & $\mathrm{R} \$ 3.583,00$ & \\
\hline $\begin{array}{l}\text { LOCACAO DE EQUIP.DE REPROGRAFIA E } \\
\text { OUTSOURCING }\end{array}$ & & & & & & $\mathrm{R} \$ 6.699,31$ & \\
\hline DESPESAS COM CONDOMINIOS & $\mathrm{R} \$ 329,69$ & $\mathrm{R} \$ 329,69$ & & $\mathrm{R} \$ 329,69$ & & & \\
\hline SERVICOS DE VIGILANCIA & $\mathrm{R} \$ 309.161,26$ & $\mathrm{R} \$ 309.161,26$ & $\mathrm{R} \$ 309.161,26$ & $\mathrm{R} \$ 309.177,46$ & $\mathrm{R} \$ 309.177,46$ & $\mathrm{R} \$ 309.177,46$ & $\mathrm{R} \$ 309.177,46$ \\
\hline SERVICOS DE AGUA E COLETA DE ESGOTO & $\mathrm{R} \$ 18.104,88$ & & & & & & \\
\hline PUBLICIDADE LEGAL E INSTITUCIONAL & & $\mathrm{R} \$ 8.685,06$ & & & & & \\
\hline OUTRAS DESPESAS DE TERCEIROS & $\mathrm{R} \$ 0,00$ & & $(\mathrm{R} \$ 129,32)$ & $(\mathrm{R} \$ 4.149,32)$ & $(\mathrm{R} \$ 4.149,32)$ & $\mathrm{R} \$ 170,14$ & \\
\hline SERVICOS DE LIMPEZA & $\mathrm{R} \$ 195.876,98$ & $\mathrm{R} \$ 195.876,98$ & $\mathrm{R} \$ 195.876,98$ & $\mathrm{R} \$ 195.876,98$ & $\mathrm{R} \$ 89.277,81$ & $\mathrm{R} \$ 303.236,62$ & \\
\hline \multicolumn{8}{|l|}{ SERVICOS DE TELECOMUNICACOES } \\
\hline SERVICOS DE GARCOM & $\mathrm{R} \$ 82.657,04$ & & & $\mathrm{R} \$ 164.273,20$ & $\mathrm{R} \$ 128.729,97$ & & $\mathrm{R} \$ 90.898,36$ \\
\hline MANUTENCAO DE ELEVADORES & $\mathrm{R} \$ 12.920,65$ & & & & $\mathrm{R} \$ 12.920,65$ & & \\
\hline SERVICOS DE RECEPCAO & $\mathrm{R} \$ 88.352,96$ & $\mathrm{R} \$ 88.352,96$ & & $\mathrm{R} \$ 244.998,76$ & $\mathrm{R} \$ 108.996,87$ & & \\
\hline DEFESA DA UNIAO NO EXTERIOR & $\mathrm{R} \$ 267.567,69$ & & & & & & \\
\hline SERVICOS DE OPERADOR DE REPROGRAFIA & $\mathrm{R} \$ 17.216,19$ & & & $\mathrm{R} \$ 16.542,96$ & & & \\
\hline SERVICOS DE ENERGIA ELETRICA & $\mathrm{R} \$ 29.135,11$ & $\mathrm{R} \$ 84.234,31$ & $\mathrm{R} \$ 89.225,44$ & $\mathrm{R} \$ 83.460,66$ & $\mathrm{R} \$ 93.649,06$ & $\mathrm{R} \$ 150.207,95$ & \\
\hline DESENVOL VIMENTO DE SISTEMAS & & $\mathrm{R} \$ 38.235,60$ & & & & & \\
\hline IMPOSTOS E TAXAS EM GERAL & & & $\mathrm{R} \$ 5.158,89$ & $\mathrm{R} \$ 185.163,16$ & & & \\
\hline $\begin{array}{l}\text { SERVICOS DE AUXILIAR DE SERVICOS } \\
\text { DIVERSOS }\end{array}$ & $\mathrm{R} \$ 111.664,98$ & & & & & & \\
\hline SERVICOS DE BRIGADAS DE INCENDIO & & & & & & $\mathrm{R} \$ 76.324,31$ & $\mathrm{R} \$ 76.324,31$ \\
\hline $\begin{array}{l}\text { LOCACAO DE VEICULOS E/OU COOPERATIVAS } \\
\text { DE TAXI }\end{array}$ & & $\mathrm{R} \$ 1.715,56$ & $\mathrm{R} \$ 9.640,44$ & & $\mathrm{R} \$ 4.074,82$ & $\mathrm{R} \$ 13.563,06$ & $\mathrm{R} \$ 4.198,25$ \\
\hline SERVICO DE COPEIRAGEM & $\mathrm{R} \$ 67.623,60$ & & & $\mathrm{R} \$ 135.247,20$ & $\mathrm{R} \$ 106.144,71$ & & $\mathrm{R} \$ 74.554,27$ \\
\hline RESSARCIMENTO DE AUXILIO-MORADIA & $\mathrm{R} \$ 2.588,67$ & $\mathrm{R} \$ 2.607,41$ & $\mathrm{R} \$ 12.323,79$ & $\mathrm{R} \$ 3.200,00$ & & $\mathrm{R} \$ 3.243,13$ & $\mathrm{R} \$ 3.316,38$ \\
\hline CENTRAL TELEFONICA & & & & & $\mathrm{R} \$ 26.090,80$ & $\mathrm{R} \$ 26.308,64$ & \\
\hline SERVICOS DE CHAVEIRO & & & $\mathrm{R} \$ 6.129,00$ & $\mathrm{R} \$ 6.958,50$ & & & $\mathrm{R} \$ 1.432,50$ \\
\hline DESPESAS SEM COBERTURA CONTRATUAL & & $\mathrm{R} \$ 12.783,98$ & $\mathrm{R} \$ 3.556,80$ & & & & \\
\hline TOTAL & $\mathrm{R} \$ \mathbf{3 . 0 0 7 . 1 3 4 , 0 3}$ & $\mathrm{R} \$ 2.541 .982,81$ & $\mathrm{R} \$ 2.439 .241,92$ & $\mathrm{R} \$ 3.145 .228,57$ & $\mathrm{R} \$ 2.683 .082,15$ & $\mathrm{R} \$ 2.692 .513,62$ & $\mathrm{R} \$ 2.359 .901,53$ \\
\hline
\end{tabular}

Fonte: Sistema de Informações de Custos do Governo Federal - SIC (2014) posição 01/10/2014, adaptado. 